University of South Florida

DIGITAL COMMONS

Digital Commons @ University of

@ UNIVERSITY OF SOUTH FLORIDA

South Florida

Integrative Biology Books

Integrative Biology

1816

\title{
Anatomy of the Tube Holothurians of the Orange Seastars and the Stone Sea-Urchins: A Translation of Anatomie der Röhren- Holothurie des Pomeranzfarbigen Seesterns und Stein-Seeigels
}

Friedrich Tiedemann

S. A. Böttger

John M. Lawrence

University of South Florida, lawr@usf.edu

Follow this and additional works at: https://digitalcommons.usf.edu/bin_books

\section{Recommended Citation}

Tiedemann, F. (2004). Anatomy of the Tube Holothurians of the Orange Seastars and the Stone SeaUrchins: A Translation of Anatomie der Röhren-Holothurie des Pomeranzfarbigen Seesterns und SteinSeeigels (S. A. Böttger, Trans., Edited by J. M. Lawrence). Herizos Press, Tampa.

This Book is brought to you for free and open access by the Integrative Biology at Digital Commons @ University of South Florida. It has been accepted for inclusion in Integrative Biology Books by an authorized administrator of Digital Commons @ University of South Florida. For more information, please contact digitalcommons@usf.edu. 
Friedrich Tiedemann

\section{ANATOMY OF THE TUBE HOLOTHURIANS OF THE ORANGE SEASTARS AND THE STONE SEA-URCHINS}

Translated by S. A. Böttger

Edited by J. M. Lawrence

HERIZOS PRESS 
HERIZOS PRESS, TAMPA

This is a translation of ANATOMIE DER RÖHREN-HOLOTHURIE DES

POMERANZFARBIGEN SEESTERNS UND STEIN-SEEIGELS by Friedrich Tiedemann

English translation (C) copyrighted 2004 by S. A. Böttger 
Translator's and editor's note:

Friedrich Tiedemann was born in Kassel, Germany, 23 August 1781 and died in Munich, 22 January 1861. He received his M.D. degree from the University at Marburg, but had no interest in practical medicine. His subsequent studies under Cuvier developed his interest in comparatiave anatomoy and morphology. Tiedeman was appointed professor of anatomy and zoology at the Landshut Medical Faculty in 1807. In 1816, the year his book on echinoderms appeared, he was elected a corresponding member of the Académie des Sciences and appointed professor of comparative anatomy, physiology and zoology at the Universityi of Heidelberg. His research involved morphology, embryology and physiology of vertebrates. His son-in-law assumed Tiedemann's teaching responsibilities in 1835 when his eyesight began to fail. He eventually became blind. The revolution of 1848-1849 affected his life. He is said to have opposed, for political and philosophical reasons, popular uprisings. His eldest son was executed under martial law and two others fled into exile. He retired from the University of Heidelberg in 1849. A medal was struck in his honoro in 1854 , the fiftieth anniversary of his doctorate.

Tiedemann's book is a classic in echinodoerom biology. It resports the results of his prizie-wiinning research undertaken in response to a question posed by the Iinstitute of France regarding the existence of a circulatory system in those animals known as echinoderms. It is a thorough analysis of the entire body system, as Tiedemann says he found it necessary to have an understanding of the whole in order to understand the parts. Tiedemann's book links the present to his time and even to his predecessors going back to Aristotle.

We have tried to preserve the flavor of Tiedemann's text by literal translation of the German terms he used except where the meaning would be ambiguous. A good example of this is Haut, which Tiedemann used for body wall, membrane, layer, tissue, etc.

The measurements were put into metric units by the equivalents:
1 Zoll $=2.7007 \mathrm{~cm}$
1 Linie $=1 / 12(2.7007) \mathrm{cm}$

Tiedemann offered his book for five ducats in vellum, four ducats in paper. A ducat was a gold coin weighing $3.5 \mathrm{~g}$.

We have not translated the Latin, Greek or even the German quotes in the footnotes. The latter occurs in Tiedemann's quotes of the German translation from the English of the book by Alexander Munro. The footnotes contain some errors that have not been changed from the original.

Of the three species Tiedemann considered, only Holothuria tubulosa has maintained its name. We have kept the names used by Tiedemann for the other two. Asterias aurantiaca is now Astropecten aranciacus and Echinus saxitilis is Paracentrotus lividius.

We have learned from this labor, not only about echinoderms but also about an extraordinary scientist and his efforts. Although it was a labor, it also was a pleasure.

(Biographic information from V. Kruta. 1974. Tiedemann, Friedrich. In: Dictionary of Scientific Biography. C. C. Gillispie (ed.). Charles Scribner's Sons, New York. Pp. 202-204. 


\title{
ANATOMY
}

OF THE

\section{TUBE HOLOTHURIANS}

OF THE

\section{ORANGE SEASTARS}

AND THE

\section{STONE SEA-URCHINS}

RECIPIENT OF A PRIZE AWARDED BY THE INSTITUTE OF FRANCE

IN 1812

BY

\section{$\mathrm{D}^{\mathrm{R}}$. FRIEDRICH TIEDEMANN}

COUNCILLOR OF THE GRAND-DUCHY OF BADEN, PROFESSOR OF ZOOLOGY, ANATOMY AND PHYSIOLOGY AT THE UNIVERSITY OF HEIDELBERG, AND MEMBER OF THE ACADEMIES OF SCIENCES AT BERLIN AND MUNICH, MEMBER OF THE INSTITUTE OF FRANCE, THE IMPERIAL SOCIETY OF NATURALISTS OF MOSCOW, THE MEDICAL SOCIETY OF ERLANGEN, THE SOCIETY OF NATURALISTS OF HANAU AND THE MINERALOGICAL SOCIETY OF JENA

\section{WITH TEN PLATES}

\author{
LANDSHUT, \\ JOSEPH THOMANNSCHEN BUCHDRUCKEREI \\ MDCCCXVI.
}


NUNQUAM AUTEM INVENIETUR, SI CONTENTI FUERIMUS INVENTIS.

PRAETEREA QUI ALIUM SEQUITUR, NIHIL INVENIT, IMO NEC QUAERIT.

SENECA 
DEDICATED

\section{TO MY DEAR BROTHER}

\section{JUSTUS TIEDEMANN}

IN

BREMEN

\section{PREFACE}

The mathematical-physical division of the Institute of France asked the following prize question in 1809:

"Investigate if circulation exists in those animals known as asteroids or seastars; echinoids, sea urchins or sea hedgehogs; and holothurians or sea cucumbers; and in the case that it existed, describe its functioning and the organs."

Already in those days I wished to solve that question. However, due to circumstances with which a German academic teacher had to deal, I was unable in order to take the expensive trip to the coast in order to solve the exercise.

In 1811 the Institute repeated the question. This came at a timely moment, as a fortunate event enabled me to take a trip to the sea. In fall 1811 I went to Triest, in the company of my former ZUHORER Doctor Muenz, whom I had asked to make the necessary drawings as I cherished his gift of detailed anatomical drawings. I spent the following five weeks on the coast of Triest with the examination of the anatomy and lifestyle of holothurians, seastars and sea urchins. During this time I understood the necessity to extend the examination of these strange 
animals from their vascular system to their complete anatomy. The reason for that decision was that the vascular system could not be explained without understanding the animals' complete organization. This particular discovery revealed a thus far unknown vascular system which occurs in these animals in addition to the circulatory blood system and which enables the animals to move.

At the end of October I collected a large number of holothurians, asteroids and echinoids, stored them in alcohol-filled containers, and returned to Landshut, to repeat and complete the anatomical examinations. In this book I have included the scattered observations and examinations of these animals that had been made previously by my colleagues, partly to prove my own experiments and partly to correct what I found in other books. Although I understood that my work might lose some of its novelty by including previous observations, I still believed it to be my duty to give proper credit to my colleagues.

In 1812 the Institute of France awarded my manuscript the prize, which pleased me even more because this decision was made by men who are honored for their accomplishments in zoology and comparative anatomy whom I admire greatly.

Whether I have really managed to completely reveal the anatomy of the strange and still mainly unknown holothurians, seastars and sea urchins will soon be determined by the examinations of other scientists, whose interest I hope to have aroused with this book. As soon as I have another chance to visit the shores of the Adriatic and Mediterranean Seas, I will continue my research and also study the anatomy and lifestyle of other generally unknown zoophytes, the actinians and jellyfish, which resemble seastars in some ways.

This book was supposed to be published already in 1812, but this was prevented by the war and the associated problems of book sellers. In 1815 I decided, due to encouragement by my friends in Berlin, to send the manuscript out on subscription, hoping that it would lead to a proper publication. The manuscript caused so much interest in Germany and some foreign countries, that now I am able to publish the manuscript properly. I also have to state that the book will not be available in book stores, but copies can be received only from me. The cost of a copy in vellum is five ducats; one in paper is four ducats.

Landshut, the $16^{\text {th }}$ of March 1816.

\section{F. TIEDEMANN}




\section{TABLE OF CONTENTS}

\section{Essay on the Structure of the tube Holothurians}

Description of the external Structure

Description of the internal Structure

Mouth, Stomach and Intestine

Respiratory Organ

Vascular System of the Intestine

Vascular system of the Tentacles, Feet and the Body Wall

Structure of the Tentacles

Structure of the Feet

Calcareous Ring surrounding the Mouth

Muscles

Reproductive Organ

Body Wall

Speculations on the Nervous System

\section{Essay on the Structure of the orange Seastars}

Description of the external Structure of the orange Seastars

Mouth and Blind Intestine

Respiratory Organ

Vascular System for the Circulation of Blood

Vascular system of the Feet, the Vesicles and the Rays

Feet and their Vesicles

Skeleton

Body Wall

Ovaries

Nervous System

Essay on the Structure of the stone Sea-urchins

Description of the external Structure

Mouth and Masticatory Apparatus

Intestine

Organ of Respiration

Vascular System for the Circulation of Blood

Vascular System of the Tentacles or Feet

Structure of the Feet

Ovaries

Structure of the test

Speculations on the Nervous System

Legends of the figures 


\section{ESSAY}

ON

\section{THE STRUCTURE}

OF THE

\section{TUBE HOLOTHURIANS}




\section{ANATOMY \\ OF THE \\ TUBE HOLOTHURIANS}

$(\text { HOLOTHURIA TUBULOSA })^{1}$

\section{Description of the external structure}

\section{(The first figure of the first table shows the living animal)}

The tube holothurian has a long, cylindrical shape. The animal can be divided into $(A)$ the front part with the mouth and tentacles, $(B)$ the rear part with the anus, $(C)$ the upper part or the back, and $(D)$ the lower part or the stomach. The front of the animal is characterized by a ring of twenty reddish-brown, bundled and fringed tentacles (a.a.a.a.), which are not located in one, but two rows that sit opposite each other. Each tentacle has the morphological shape of a small cylinder with a wide end, that terminates in five or six branches or fringes ${ }^{2}$. In the middle of these branches located is a type of sucker. The holothurians can extend and draw in these tentacles, as I will describe later in the anatomy of the tentacles. Within the ring of tentacles is a round, expandable and contractile mouth opening $(b)$. This opening, as well as the ring of tentacles, which I will call the head, is not right at the front of the animal but rather turned towards the side, which enables the animals to pick up food. Above the ring of tentacles lies a fold of the body wall $(c)$ under which the animal can hide the tentacles and the mouth opening so that they are no longer to be distinguished as separate parts. The retraction of tentacles and mouth takes place when the holothurian is taken out of the water; and even if in the water, when it is touched or irritated. Right behind the fold of the body wall is a small, round opening $(f)$, the end of the genital duct.

\footnotetext{
${ }^{1}$ Genitale marinum i Petri Bellonii Schrift, de Aquatilibus Libri duo. Parisiis 1553. P. 441.

Holothuriorum prima species in G. Rondeletii Werke: Universae aquatillium Historiae pars alters. Lugduni 1555 fol. Liber de Insectis et Zoophytis p. 125. Cap. 19.

Holothurii prima species Rondeletii in Aldroyands Werk, De reliquis Animalibus exanguibus Libri quatuor. Bononiae 1606 fol. p. 580.

Hydra Linnaei in System. Natur. Ed. 6.

Hydra, described by I. B. Bohadsch in his publication, De quibusdam Animalibus marinis. Dresdae 1761. 4. Cap. 4. p. 75 de Hydra.

Holothuria tremula Linnaei, in System. Natur. Ed. 12.

Holothuria tubulosa in Linnaei System. Natur. Ed. 13.

Holothuria timide of Mr. Cuvier, in his Tableau Elémentaire de l'histoire naturelle des animaux, Paris Ann. 6. p. 644.

${ }^{2}$ Belon has described the tentacles quite correctly. A. a. O. p. 441. Ex anteriore autem capitis parte rursus crinitas emittit veluti arbusculas acetbulis plenas, quibus quidquid palpat, ad os adducit.
} 
Holothurians always move with their head first with extended tentacles that locate every object in their way, in the way performed by terrestrial snails. If they encounter another living creature, for example a crab, they are able to draw in their tentacles and move away from the other creature. With the help of the tentacles holothurians can also attach themselves to hard surfaces by suction ${ }^{3}$, and they then cannot be moved without a considerable amount of force. I have often observed this phenomenon in the wooden containers in which I kept the holothurians as well as in rocky areas of the sea. Holothurians are further able to move upwards on perpendicular objects by the help of the tentacles and the later described feet. The tentacles were therefore not only used as sensors but also for locomotion.

The lower part or the stomach of the tube holothurian $(D D)$ is of white-brown color and shows a large amount of blind ending, small tubules. I counted nine hundred of these tubules on a large holothurian. These tubules show sucker-like dents at their free or lower end, with which the animal moves by extending the tubules forward and sucking onto the substratum. A part of those tubules is attached to the substratum while the other is free and extends forward in the direction of the animals' movement. As these tubules are the best adapted locomotory organs of this holothurian I will call them feet. These feet can be extended and drawn in by the animals as already described for the tentacles. The way in which this is done will be explained later. The feet, as the tentacles, are also very sensitive to touch or irritation and will be drawn back when touched by another creature. Again, as described for the tentacles, the animals are able to use the feet to attach themselves to their substratum from which they can then only be removed with a certain amount of force. With the help of these attachment organs the holothurian can therefore move up and down on angled and perpendicular substrata, as I have observed numerous times on the walls surrounding the harbor. Because the feet can be considered as the main locomotory organs of the holothurian, I call the part of the body they are located on the lower part or the stomach.

The complete upper part and sides of the animal are of black-brown and sometimes reddish-brown color, wrinkled longitudinally and show long, cylindrical warts. Some animals have more, some fewer of these warts (e.e.e.). On a large holothurian I counted approximately fifty large and two hundred small of these warts scattered randomly over the surface of the animal. Out of each of these warts a tubule is exerted, which is $0.5-1.0 \mathrm{~cm}$ long, depending on the size of the warts. These tubules are analogous to the feet already described for the stomach, as they have small suckers at their ends. These tubules also enable the animal to attach to their substratum. The animals do not use them for normal locomotion, but only if they have fallen or were turned onto their back. In this case they are use to turn the animals back onto their stomach. The tubules on the warts, as the tentacles and feet, are extremely sensitive and the animals are also able to extend and draw them back necessary.

3 Bohadsch de Hydra a.a.O. p. 80 has also observed this phenomenon: Ope horum tentaculorum hydra in fundo maris morans corpus sum firmat, ne a procellis facile avelleretur, quod sane eo frequentius fieret, cum hocce Zoophytum genus ad littora maris habitet, ubi aquae ad sex pednm altitudinem vix elevantur. 
Towards the back part the animal's body $(B)$ diminishes its circumference and ends pointed with a round opening the animal can open and close. Within these openings lie round, black and contractile pieces of skin (Figure 1, $2 a$ during contraction). This skinfold closes the opening when it contracts and opens it, when it expands (Figure 1, $3 a$ during expansion). Through this opening water enters the body of the holothurian, generally once or twice a minute, as I have observed when the holothurian was located in a water filled container, in which the water only covered the body of the animal by an inch. Soon after the animal has drawn the water into its body it will squirt it out through the same opening again. The expelled water is often colored and mixed with excretions and slimy threads. If the holothurian is taken out of the water it squirts this internal water out quickly, which might have lead to the animals Italian name, Cazzo di mare, which particularly the Italian fishermen have given this holothurian. Sometimes the animal also squirts out its internal water in small fountains ${ }^{4}$, when kept in a container with little water. The drawing in and squirting out of water can be compared to breathing in and out. The posterior opening of the animal leads into a sack, in which the intestine and both branches of the respiratory organ end. I will therefore call this opening the cloaca or anal opening..

The folded skin of the holothurians produces a dirty-white, sticky excretion, which can be black in some cases. Together with this excretion pieces of skin are sometimes extracted.

If a living holothurian is taken out of the sea water, its whole body contracts and the water drawn in previously will be squirted out forcefully due to this contraction. The front part of the body with its tentacles and the rear part are drawn into the body so strongly that the openings are no longer visible. Feet of the stomach and wart tubules of the back are also drawn back into the body. A holothurian of fourteen inches can shorten its body to eight to ten inches, and the shortening transforms the animal's body into a short, thick object. The extreme shortening of the body often leads to complete extraction of the intestinal tract with all associated vascular systems and the free branch of the respiratory organ through the cloaca ${ }^{5}$. This phenomenon occurs most easily when animals are left in air, freshwater or alcohol. Holothurians expel, through convulsive movement, the intestine, vascular systems and attached respiratory branches, which tear of at the stomach. A holothurian that has expelled its organs in that fashion will survive for two more days when kept in a water filled container. During this time the animal will continue to move in the container, and extend its tentacles and feet. It also continues to breathe, but the water taken in will enter the coelomic cavity of the body and the animal will swell, which stretches the animal's skin greatly. After a while the animal's movements will slow down, breathing occurs less regularly, tentacles and feet lose their sensitivity and contractility, until they are only drawn in weakly. The animal's swollen body will finally remain at the bottom of the container, the animal will cease breathing and tentacles and feet will hang limp on the body. In this stage, weak contractions of skin, tentacles and feet will only occur through Galvanic stimulation. Finally the animal will die and its body will start decaying. Through the observations just explained as well

${ }^{4}$ Bohadsch already has described this very correctly thusly a. a. O. p. 82: Jucundissimum sane spectaculum intuenti praebet hocce Zoophytum, dum in vase aqua marina pleno detinetur, ita tamen, ut aqua ultra duos pollices supra Hydrae corpus non elevetur. Tunc enim maxime vero dum anum aliquantum elevat, omni fere minuto temporis aquam marinam ad duorum fere pollicum altitudinem extra superficiem aquae, in qua continetur, ejaculat; atque hac ratione admirandam novique prorsus generis fontanam repraesentat. Multo longius vero eandem e corpore propellit, dum recens e fundo maris extrahitur, atque fortiter manu contrectatur. Nam hac occasione aquam haustam ad duos etiam pedes ejicit, corpusque ejus instar ligni indurescit, quae indurescentia, aquae per anum ejaculatio una cum cylindrica corporis forma, ansam potissimum dedisse videtur, quod hoc Zoophytorum genus Veteres Mentulam, et Itali obsceno nomine casso de mare appellarent.

5 This phenomenon has already been observed by Redi, as can be concluded from a letter to Cestoni of 30 December, 1682, published in the Académiq. De la partie etrangerè T.4, p. 587: Des priapes de mer que vous m'avez envoyé, il ne s'en est trouvé qu'un seul qui n'eut pas rendu ses boyaux et qui m'ait pu servir à verifier ce que j'en avois observé ces années passées. 
as an experiment, described shortly, it becomes obvious that a holothurian is a very resistant animal. I placed holothurians into a container filled with alcohol, in which they contracted heavily, expelled their inner organs and their skin started excreting a large amount of black mucus. After an hour the animals still contract strongly, and it was only after an hour and thirty minutes that all animals were dead.

The tube holothurian occurs on rocky and sandy seashore ${ }^{6}$. In these habitats they move in the previously described way on the sea bottom and on stones and boulders, as I was able to observe a number of times in Triest while the sea was calm. Especially in the harbor and where ships are repaired are these animals are found. They find their food, which mainly consists of small mollusks (I have found the stomach and intestinal tract of these animals generally filled with mollusk shells), in the sand and on stones. The holothurians are unable to swim, at least as far as I have observed, and they lack organs to perform this type of locomotion ${ }^{7}$. With low tide holothurians often remain in the sand and on stones. In case the sun is very hot, the animals will die before the tide comes back in. If, however, the holothurians lie in the shadow and at a wet place, they can survive the low tide. If the sea is rough they will attach to stones or other solid substrata. It can happen that the wave action is strong enough to detach them from their substratum which leaves them unmoving on the sea floor if they are not thrown onto the beach during very strong wave action.

The size of the tube holothurian can vary, depending whether the animals' body is relaxed or contracted. The largest of these holothurians that I have seen in the Adriatic Sea were $18 \mathrm{~cm}^{8}$ in length and $2.5 \mathrm{~cm}$ in width in their relaxed state. One of the largest living animals I collected, is represented in Figure 1 of Table 1. I have also collected small holothurians, which measured only $3 \mathrm{~cm}$ in length. Regarding the dissimilar sizes I assume that holothurians live for a number of years.

\section{Description of the Internal Structure}

An examination of the interior structure of holothurians proved rather difficult ${ }^{9}$. When trying to separate the animals into different parts, the skin contracted with the first cut of the scalpel and all inner organs were expelled if the scalpel penetrated deeply. The attempted to kill the animals in alcohol either lead to excretion of the inner organs through the cloaca or the intestine is torn of the stomach and lies in the posterior part of the animal's body. I have dissected living and dead holothurians by binding off the posterior opening to prevent the excretion of the interior organs followed by nailing the animals' body to a wooden board or killing it in ethanol. In this fashion I was often able to dissect animals without disturbing their internal structure. To achieve an exact understanding of the structure of the internal organs I have dissected approximately two hundred animals. All peculiar structures I found have been

\footnotetext{
${ }^{6} \mathrm{P}$. Bellonius a. a. O. S. 441 has already said this: Genitale marinum litorale est, neque alibi reperitur, quam ubi patellae, ricini et vertibula degunt.

${ }^{7}$ Bellonius has described the locomotion of the holothurians very correctly a.a.O.p.441:Genitale ex hoc dicitur, quod teres sit, pedem longum et mediocris brachii crassitudinis: distendit se ac contrahit hirundinis in more, unde et ei nomen inditum est: quin etiam rufi coloris est. Iners, nec nisi serpendo incredit, aspectu toroso, Nympheae radicis similitudine: semper ad ima sedet: nunquam natat: contrectatumque in se ipsum contrahitur, ac cornu duritem habet, vixque acuta cuspide pertundi potest: alioqui permolle, dum sua sponte movetur: suas promuscides quando vult exerit, atque ita constringit, ut ex pedali longitudine vix sex digitos longum appareat. Acetabulis, quae in promiscidibus habet, lapidibus hae ret: in quibus plus quam quatuor millia non nunquam annumeres.

${ }^{8}$ I have to remark here that I have used the measures of Paris for the measurements of the different body parts

${ }^{9}$ As Otto Friedrich Müller in the Zoologia Danica has already remarked: Holothuriae adhuc viventos dissectio difficillime instituitur ob contractilitatem cutis summam: sectione enim vel longitudinali vel transversali facta, cutis momento citius sese contrahens crispatur, nec vi quamvis maxima adhibita in pristinam formam extenditur.
} 
illustrated. I have opened the body of the animals from the top, the bottom, the sides, to be able to study the exact location of all internal structures.

\section{Mouth, Stomach and Intestine}

The mouth is, as already described, located within a ring of tentacles and is turned downwards, which aids feeding. The round mouth is surrounded by strong, dirty-white skin, which is extremely flexible and contractile. It does not contain any teeth, but instead the animals use the callous skin of the mouth to crush fragile shells of mollusks. Located inside, right behind the mouth opening is the beginning of the intestinal tract ${ }^{10}$, which leads through a calcareous ring, on which the later described long muscles of the animal attach.

The intestine (Plate 2 Fig. 6. a.a.a.a.a.a.a., from a holothurian opened at the stomach) is located on the right side of the animal. It is folded towards the back and bends at the posterior part of the stomach next to the cloaca, where it is then folded and leads in the middle of the body back to the front. There it is bent again next to the first part of the intestine to the back and is then lead back in eight to ten folds to the end of the body, where it opens into the cloaca. The complete intestinal tract is attached to a short duplication of a very thin, white membrane that lines the body cavity. This membrane is analogous to the human diaphragm, and the duplication that stabilizes the intestinal tract can therefore be called the mesentery (Plate 4. Figure 8. a.a.a. shows a part of this mesentery). The mesentery shows two main bends, just like the intestinal tract.

[Anne: The following paragraph is incomplete. The paragraph is: Die angegebenen Schlangeluingen des Darmkanals begunstigen die Ausdehnung und Zussamenziehung des Thiers ungemein; den ist dast Thieir ausgedehnt, wie es beim Kriechen der Fall ist, so wird der Darmkankal mehr in die Lange gezogen und die Schlangelungen verschwinden grosstentheils; ist das Their aber zusammen-gezogen, so dind die Schlangelungen des Darmkanals sehr betrachtlich.]

The described folds of the intestinal tract favor the expansion and contraction of the animal greatly. If the animal is expanded, as in case of locomotion, the intestinal tract is stretched and the folds are mostly removed. In case of contraction of the animal, the folding of the intestinal tract increases extensively. showed

The length of the intestinal tract of a 10-mm long tube holothurian had a length of $31 \mathrm{~cm}$. The skin of the intestinal tract is very thin, so that substances on its inside can be seen through the skin. It is covered on the outside with a thin, white and even membrane that is the extension of the mesentery. Located below this mesentery is another layer that is mainly composed of vessels. I was able to discover thin, transparent, white muscle fibers in some large animals. The inner membrane of the intestinal tract is even and does not show circular but longitudinal folds. These longitudinal folds only occur on those parts of the intestine that do not contain any food or excretions at that particular time.

The first part of the intestine, following the mouth, is wider than the rest of it and his thicker walls. I will call this part the stomach. This stomach is constructed of a long, oval sack. In

\footnotetext{
${ }^{10} \mathrm{O}$. Friedrich Müller has illustrated well the intestinal tract of Holothuria pentactes in the third volume of the Zoologica Danica, Tab. 108. It is also described well in the fourth volume on page 4.

Mr. Cuvier has described the intestinal tract of Holothuria tubulosa very correctly in his Anat. Compar. T. 4. p. 143.
} 
a holothurian of $10 \mathrm{~cm}$ in length this sack was $1.3 \mathrm{~cm}$, from the mouth opening to the beginning of the intestine. The diameter in the middle was approximately $0.5 \mathrm{~cm}$. The inner skin of this stomach is yellow-white and much thicker than that of the remaining intestine; it also shows distinctive longitudinal folds and seems glandular. These longitudinal folds end in a short, round fold of the skin. Immediately behind this skinfold the intestinal tract decreases in diameter. On the stomach longitudinal and circular muscle fibers can easily be identified. In it, I often found a yellowish, bitter liquid, produced by the glands in the stomach's skin, as a liver or a similar organ does not exist. From all of my findings I drew the conclusion that the first part of the intestine has to be the stomach.

From the beginning to the end the intestinal tract narrows slightly, which can be detected especially where it leads into the cloaca. The cloaca (Plate 2. Figure 6. b.) is long, oval and attached to the inner body wall by large numbers of muscle fibers. These muscle fibers arise from the horizontal musculature of the skin. The length of the cloaca is approximately $1.5 \mathrm{~cm}$, its width $1 \mathrm{~cm}$. The branching intestinal tract and the main branch of the respiratory system terminate in the sack of the cloaca (Plate 2. Figure 6. D.). The anus is a muscular sack made up of longitudinal and horizontal muscle fibers. Inside the anal cavity is layered with a white, smooth, slime producing skin, that is extended partly into the intestine and the branching respiratory organs. It has to be remarked that excretory products never accumulate in the anal cavity, or that I have at least never observed an accumulation of excretions in it. Instead the excretory products are emptied into the anal sack and from there transported out of the animal with the next muscular contraction and water exchange from the respiratory organs. Excretion takes most likely place with each expiration, because the skin of the animal contracts and the contracting branches of the respiratory system, located next to the end of the intestine, create a pressure on the intestine and induce the emptying process.

In a living, dissected holothurian the alternating expansions and contractions of the intestine, or peristaltic movements, can be observed. These alternating movements are stronger if the intestine is stimulated with a sharp instrument or alcohol. The intestinal tract of all examined holothurians, contained a grayish-black, sometimes brown-green, sandy mass. When washed with warm water, flushing away its small, thin parts, a large amount of small mollusk shells, some complete, most broken, remained. I have seen shells of uni-shelled mollusks of the genus Strombus, Terebra, Buccinum and Murex ssp. and of two-shelled mollusks of the genus Tellina, Solen, Venus, Donax, Pecten and others. The size of the mollusk shells differed from one to two lines. The mollusk species could not be identified further, due to the small size of the shell. Because most of the shells were complete, it can be assumed that the stomach liquid digested only he soft parts of the mollusks, the shells remain unchanged. Pieces of broken mollusk shells were found due to the destructive pressure of the callous skin of the mouth. Also found in the intestine is sand ${ }^{11}$ and sometimes pieces of macroalgae. Pieces of those are possibly taken up accidentally with the uptake of the mollusks.

As the intestines of all dissected holothurians were filled with mollusk shells, it seems as if the holothurian take up large amounts of their main food, and diminish the recruitment of the fertile mollusks greatly.

\footnotetext{
${ }^{11}$ Redi also found sand in the intestinal tract of the holothurians: De animalculis vivis, quae in corporibus animalium vivorum reperiuntur. Amstel. 1708. 12. p. 134.

Nec soli forte lumbrici terrestres terra vescuntur; observavi enim, in omnibus longissimis intestinis quorundam insectorum per fundum maris vagantium, quae Priapi marini vocantur, saeplus nihil occurere aliud praeter minutissiman arenam qua refera sunt.
} 


\section{Respiratory Organs}

The respiratory organs consist of two large, long, hollow and branched objects that, attached to each other by a branch of five to six $\mathrm{cm}$, derive from the anterior part of the anal sack, right next to the entrance of the posterior intestine in to the $\operatorname{sack}^{12}$ (Plate 2 Figure 6.d.e.e.e.e.). The right main branch of the respiratory organ is located in the first main fold of the intestine, between the part of the intestine that runs from the mouth to the posterior, and back to the anterior end. The branch is webbed with the vascular systems from the intestine. This, with the vascular intestinal systems connected, branch, which stretches to the stomach, is expelled from the animal's body, if it expels the intestine, also. The left main branch of the respiratory organ is located in the second main intestinal fold, again between the part of the intestine that, coming from the mouth, turns towards the posterior and the back to the anterior end, that ends in the anal sack. This branch is not linked to the intestine, but attached to the inner surface of the skin by white, $0.5 \mathrm{~cm}$ long, muscular threads, coming from the horizontal muscles. This part of the respiratory system is therefore never expelled, in case the animal rids of the intestine. The branch stretches to the anterior part of the animal's body, towards the calcareous ring, which surrounds the mouth. It becomes smaller, the closer it gets to the oral opening.

Each main branch of the respiratory system divides into smaller sections from the front to the rear, which again branch further. Located on the smallest branches are small leaves, shaped like long, small vesicles. Each branch is made out of three layers of skin; the outer, the muscular and the inner skin. The very thin outer skin is shiny and smooth and forms a continuation of the thin inner skin, which is analogous to the diaphragm, and all organs located on the inside of the animal's body. Below this layer lies a muscular skin layer consisting of very fragile longitudinal and horizontal muscle fibers. These muscles are easily detected with the bare eye on the main and side branches of the respiratory organ. On the smaller branches or vesicles they can only be seen with the magnifying glass. The inner skin is smooth and slime producing, and is a continuation of the smooth inner skin of the anal cavity. This skin continues into all branches and the vesicles. The walls of the respiratory organ contain a large amount of starch. In dead animals, kept for some time in alcohol, I was able to inject the respiratory organ with a colored mass of wax. Some of those preparations still remain in my anatomical collection.

When breathing in, water enters through the posterior elastic opening into the anal cavity, which expands. From there water enters all branches and respiratory vesicles and reaches to the end of the respiratory organ. When breathing in, the branches of the respiratory organ increase to double their normal diameter. During exhalation all parts of the respiratory organ contract

\footnotetext{
12 The respiratory organ of Holothuria pentactes is described in Zoologica Danica, Vol.4, page 4. and shown on Plate 127. He is of the opinion that this part is in fact the reproductive organ or the ovary, but my examinations have found this to be incorrect.

Mr. Cuvier has described admirably the respiratory organs of Holothuria tubulosa in his Leçons d'Anatomie comparée. T. 4. p. 443: Les Holothuries, de moins l'holothuria tubulosa, que j'ai observée vivante, n'ont point de ces tubes saillans à l'éxtérieur; mais on y observe un organ interne qui ne peut manquer d'y avoir rapport: c'est un ou plusieurs arbres membraneux et creux, dont le tronc communique au-dehors dans ce même cloaque, où se rend l'anus: il se porte dans l'interieurre du corps, se devise et subdivise en branches; et celles-ci enfin, en petites productions coniques; d'espace en espace les branchies se renflent en vésicules, et en général on les trouve plus ou moins gonflées d'eau, selon l'état où l'on disséque chaque sujet.

Dans l'Holothuria tublosa, il n'y en a qu'un seul tronc, qui se partage des sa naissance en deux branches principales; l'une des deux marche le long de lenveloppe, général, et lui reste adhérente par une espèce de mésentère; l'autre se glisse entre les intestins, et entrelasse ses rameaux avec les vaisseaux que j'ai décrits dans l'Article IV de la prémiere section, et qui communiquent de l'un des grands trons vasculaires à l'autre. Cet entrelacement est si intime, qu'on ne peut d'égager les deux systémes sans les dechirer; et il y a grande apparence qu'il se fait à cet endroit une communication entre la fluide nourricier et le fluide ambiant.
} 
recognizable, as I was able to observe in living animals. Now the water streams back from the main branches into the anal cavity, which also contracts and forces the water out of the animal's body. The previously described phenomenon that an animal taken out of its habitat and forcefully squirts out its internal water is caused partly by this contraction of the anal cavity. However, more than the contraction of the respiratory organ and the anal cavity, namely the contraction of horizontal and longitudinal muscles of the skin, that are necessary to cause it. The skin is forced against the respiratory organ, which increases the amount of water squirted out. I have observed that the effect of the skin muscle is important in animals that were cut open longitudinally and the skin pulled back. These holothurians were then still able to breathe in and out but unable to force their internal water out. The contraction and expansion of the branching respiratory organ of a living, opened holothurian is an extremely beautiful view.

The venous blood coming from the intestine, possibly mixed with the chylus, is lead to the right branch of the respiratory organ by the blood circulation, that will be described later. These circulatory canals construct a fine system of nets which are located on both sides of all parts of the respiratory organ. The water taken up by the respiratory organ seems to oxidize through the walls of the respiratory into the circulatory canals. This occurs in the same fashion in which lung breathing animals show an oxidation of air through the bronchi into the lung arteries. The water entering the left branch of the respiratory organ seems to add to the oxidation of the liquid of the other organs and the skin, which is not covered in the fine net of the blood circulatory canals. As air enters the air sacks of birds through the lungs this branch of the respiratory organ possibly influences the oxidation of the blood circulating in the different organs. The respiratory organ of the holothurian therefore resembles a lung that breathes water instead of air.

The uptake and excretion of water in holothurians, or breathing in and out, take place approximately 2-3 times per minute. After the uptake of a certain quantity of water, the spherical opening of the anus is closed. The water taken up, or breathed in, remains about 16-20 minutes within the respiratory organ, if the animal is not disturbed and is maintained in sea water. After this time the anus opens again, the water is expelled and the animal contracts slightly. If the animal is stressed by touch, and it contracts and retracts its tentacles and feet, the water is expelled violently in form of a fountain. During this contracted condition the animal does not take any water up, which means it does not breathe, but it remains without movement. After some time, approximately 2-4 minutes, if the animal maintains undisturbed, it starts to relax its body, the anus opens and the animals starts to breathe, even before tentacles and feet are extended. If the animal is continuously stressed by touch over a period of up to 15 minutes, the contracted state is maintained and the animal starts to get restless and moves towards all part of the container. This phenomenon probably derives from the disturbed respiratory process.

The anatomy of the respiratory organ of the holothurians strongly resembles the branching of the bronchi of lung breathing animals. The true nature and anatomy of the bronchi is demonstrated in the respiratory organ of the holothurians. The inner skin of the trachea demonstrates the same way of branching into smaller branches and ends in small alveoli, as the respiratory organ of holothurians. The number and size of the branches and alveoli differs between animals of the first three animal classes. The size of the alveoli regulates the intensity of the respiratory process; that means that the smaller and more numerous the alveoli, the stronger and faster the blood is oxidized and the faster the animal has to breathe. The oxygen taken up with the air, encounters the inner skin of the alveoli faster, and is so taken up faster through the alveoli, oxidizes the blood and is consumed at a much higher rate. This explains the faster respiration and oxidation of the blood in mammals and birds. The larger and more voluminous the alveoli, the slower the oxidation of the blood and the slower the respiratory process of an animal. The reason for this is that only a part of the air is in contact with the circulation which leads to the slower breathing and decreased oxidation of the lung circulating blood in reptiles. 
The anatomy and lifestyle of the respiratory organ of the holothurians lead to the analogous conclusion, that bronchi during respiration in animals are active. This means that they expand during inhalation, or water uptake, and contract when exhaling, or excreting water. This is stressed by the presence of white-reddish stripes on the bronchi of humans, mammals and birds, which in higher mammals are real muscle fibers, and which do not have any function other than the contraction and expansion of the alveoli.

If a number of holothurians are maintained in water for 12-18 hours, with the water becoming clouded by their excretions, I have often observed that those animals move the hind part of their body towards the surface of the container and seem to take up air through the opening of their cloaca. This possibly occurs, because the water is too dirty to sustain normal breathing, so that the animals moved to new and cleaner water layers, and finally, in lack of oxygen in even the upper layers, ended up breathing air. If a holothurian was moved into clean water, following a period of being maintained in dirty water, it did not breathe air any longer but remained on bottom and walls of their container and took in water only.

Holothurians that were kept in a 15 liter wooden holding tank, in which the water was not exchanged for approximately a day, died. In the beginning they breathed air in the previously described way more often than water, even if it was still clean. Following this they seemed to weaken and sink to the bottom, moved more rarely and contracted more slowly when they were touched. The reaction of those animals to stress will be reduced further until they sink to the bottom and die, with expanded body and placid tentacles and feet.

Holothurians, which I ligated at their posterior end to inhibit this form of breathing, started strong movements in the container, which often made them lose the ligatures. If the thread was tied very strongly, and the animals could not remove the ligature, the strong movements were maintained for a longer time. They finally ceased and the animals died after a few hours, softened slowly and their feet and tentacles became placid. If a holothurian was kept in freshwater, the animals will also breathe in the previously described fashion, moving to the surface, and finally die in the described fashion. This experiment lead me to conclude that in freshwater the animals were not capable to maintain their respiratory processes. Unfortunately, due to a lack of chemical equipment, I was unable to experiment with holothurians in water, which was satisfied with different gasses.

\section{Vascular System of the Digestive Tract}

\section{(Plate 3. Figure 7.)}

I will now turn to the description of the vascular system, whose account is amongst the most difficult ones of the holothurian anatomy; this is partly due to the transparent nature of the vascular system and the body fluids, which make it difficult to follow it. It is also partly due to the thin and fragile nature of the walls of the vessels, which makes it difficult to inject dyes into the system to increase its visibility. The injection of normal anatomically used dye is indeed impossible, because the touch of the hypodermic needle will tear the vessels open. I have therefore used the set up that is used to fill vessels with mercury to present them to the eye. This set up is made of a glass cylinder, onto which a fine steel tube is screwed, which can be opened and closed manually. Mercury is ideal for injecting fragile vessels, because it is highly soluble and will enter the vascular systems through its large gravity without force. In the beginning I tried to inject the vascular system of living holothurians. This showed success in some cases, however, the fragile vessels would still tear up quickly and the mercury would leak out. To increase the toughness of the vascular canals I preserved dissected holothurians in ethanol for a few days and did the injections after an adequate preservation time. This method made it possible, with the 
highest degree of patience and repeated experiments, whose success I started to doubt seriously, to fill the complete vascular system of digestive tract and respiratory system with mercury. The description of the vascular system was done after the successful injection and Plate 3 shows the vascular system with mercury injection.

The upper, free end of the digestive tract harbors a vessel (Plate 3, Figure 7 a.a.a.a.a.a.a.), which contains a yellow or light brown fluid in living holothurians. This vessel is largest on the middle or second section of the digestive tract, and becomes smaller towards the first section and the stomach as well as towards the posterior third section and the cloaca ${ }^{13}$. From the largest part of this vessel, two other vessels $(b . b$.$) arise that are united to one branch in a$ pointed angle $(c$.). This branch runs from the second to the first section of the digestive tract where it connects to the vessel located there, and forms a large anastomosis. I have cut through this structure, inserted the steel tube in the end of the cut vessel $(d)$, closed off the other end of the vessel $(e)$ and began injection of the mercury.

A large number of vascular canals arise from the vessel, leading to the first section and the stomach, which mostly separate from the main vessel in a right angle. These branches divide at the other, posterior part of the intestine in very fine side branches, that form a net of vascular canals. ( The vessels of the intestine are displayed very well on Plate 7). This vascular net is not visible without the injection of mercury. If, however, the vascular system is mercury injected this vascular net is highly visible at the anterior as well as the posterior part of the intestine. The main vessel, which narrows out towards the stomach, forms a small ring of vessels around the stomach, at approximately the location of a fold similar to the closing fold, next to a ring of another part of the vascular system that will be described later. From this ring of vascular canals (f.) arise small branches that lead anteriorly and form an enlargement in the area of the stomach and the ovaries that I shall also describe later.

The other, or posterior part, of the main vessel leads to the posterior and final part of the intestine towards the cloaca, becoming smaller in the direction of the cloaca. This vessel also branches into many smaller side branches towards the anterior and posterior end of the intestine and forms vascular nets. The vessel itself, with its fine and last branches, ends on the cloaca.

I will relate to the previously described vessel stem (a.a.a.a.) with all its side branches as the intestinal artery or aorta. It is obviously an artery, because of the observations in a living holothurian, that the vessel would slowly contract and expand from its middle to the ends, and therefore move a brown fluid, the blood, towards both ends. If the vessel was stimulated with a needle or ethanol, the force of the contractions increased. The smaller side vessels that branch on the intestine may well nourish the intestinal walls through the blood and may also release the digestive fluid that is then added to the food in the stomach and intestine. The suggestion that more than one artery branch ends in the intestinal space is related to the observation that a quantity of the injected mercury always enters the intestinal canal itself.

The anterior as well as the posterior branches of the intestinal artery turn into vascular branches at the inner rim of the first intestinal section, where they combine to larger branches and finally into two main canals. These vascular canals comprise the large net displayed on Plate 3 (Figure 7. g.g.g.g.) The vessels have a larger diameter and thinner, more fragile walls than the intestinal artery; they tear apart easily during injection. At injection the mercury will pass from the aorta, or intestinal artery, to its branches and from there through the smaller branches into the two main vessels described (h.h.). I therefore characterized those main vessels as veins and called them intestinal veins.

\footnotetext{
${ }^{13}$ Bohadsch has described these vessels very superficially a. a. O. de Hydra p. 87 and poorly illustrated them Tab. 6. Fig. 5.
} 
It is very likely that the nutritional fluid or chylus is absorbed by the fine side branches of the intestinal veins, directed into the vascular system where they mix with the venous blood. The following reasons lead me to this suggestion:

1) I have not found any sucking veins, however, not out of lack of trying;

2) all vessels, which originate from the first intestinal section, are much larger in diameter than those branching from them;

3) the quantity of fluid contained within the intestinal veins is much larger than then quantity within the intestinal arteries; and

4) the fluid contained within the veins is much more transparent than the one in the arteries

Both main stems of the intestinal veins (h.h.), which ascend out of the vascular net, combine after a short length to one stem (i.i.i.), from which a large number of branches, about 34-36, of all sizes originate (k.k.k.k.k.). All those branches form vascular bundles, which are located on and entwined with the branches and alveolas of the right branch of the respiratory organ. The right branch of the respiratory system lies, as previously described, between the first and second section of the intestine. In the vascular bundles the branches turn into different vascular canals that divide into branches on the second intestinal section as the others do on the respiratory organ. All capillaries coming from the right branch of the respiratory system (l.l.l.l.l.) end in a vessel located on the inner rim of the second intestinal section.

On injection of the intestinal artery, the mercury entered the intestinal veins, and dispersed from the vein stem into the branches, and from there into the branches located in the inner rim of the second intestinal section. The branches entwined with the right part of the respiratory organ, when mercury injected, show a strikingly fine net system, in which the connection of the small vessels with each other can be well studied. This net system was an incredibly pretty sight. The second plate (Figure 5.f.) shows the webbing and twisting of the vascular bundles with the right branch of the respiratory organ.

It can be concluded from all of this, that:

1) the intestinal vein stem branches in the style of an artery on the right respiratory branch and is analogous to an artery of the respiratory organ or a lung artery;

2) the fine artery branches turn into the fine venous branches;

3) the vascular canal located on the inner rim of the second intestinal section is compatible

with a respiratory vein or a lung vein.

The branching of the vessels on the right respiratory branch, and the connections between the fine arteries to the fine veins shown with mercury injection, possibly enable venous blood, coming from the first intestinal section, mixed with the chylus, in fine vessels located on the respiratory organ to be oxygenated and turned into arterial blood through the water taken up in the respiratory organ ${ }^{14}$. This is suggested by the fact that the blood in the respiratory or lung vein is less transparent, and more brownish than blood in the intestinal vessel. The color change of the blood that has been channeled through the right respiratory branch is possibly brought about by the influence of the water on the blood.

The stem of the respiratory or lung vein (m.m.m.) projects all its branches to the inner intestinal rim, from where they lead to the anterior and posterior surface of that particular intestinal part, and open into the largest arterial section. I was able to study the access of the branches of the respiratory vein to the wider section of the intestinal artery through injection, because the mercury always flowed from those branches into the arterial stem, even when I had ligated the artery at the first intestinal fold (at $n$.). The venous blood coming from the third intestinal section also enters the respiratory vein (at $o$.).

\footnotetext{
${ }^{14}$ Mr. Cuvier has proposed this idea first in his Anatom. Compar. T. 4. p. 414.
} 
This connection of the respiratory vein with the stem of the intestinal artery indicates that the blood oxygenated on the right respiratory branch is transported into the intestinal artery. From here it moves through the arterial branches to the intestine, the stomach, the ovaries and the cloaca. The blood is transported into that body parts through contractions of the intestinal artery, which contracts from its stem partly towards the first and partly towards the third intestinal section. The intestinal artery also receives and distributes the oxygenated blood.

These facts and concluded descriptions of the layout, intertwining and connections of the vascular system of the tube holothurian suggest a blood circulation in those animals without the aid of a heart, but simply through vascular contraction.

This hypothesis is supported by the following facts:

1) I have studied the contractions of the intestinal artery and the movements of the blood contained in it in living dissected holothurians;

2) I have shown through mercury injection, that the intestinal artery interpolates into the intestinal vein;

3) the injected mercury was transferred from the intestinal veins into the smaller capillaries of the right respiratory branch, from where they were transported into the respiratory vein;

4) the mercury was then conveyed from the respiratory vein through branches into the medium and widest part of the intestinal artery stem.

The vascular system of the digestive tract does not relay any capillaries to the body and its muscles, the tentacles and the feet; or at least I never observed such a connection even with the best mercury injections.

\section{Vascular System of Tentacles, Feet and Skin}

Along with the vascular system described for the digestive tract, the tube holothurian also contains another extremely peculiar vascular system, which I had the luck to discover. At least I have not found any reference from other natural historians and anatomists about this vascular system. I will therefore describe it exactly the way I have found it during repeated dissections and injections. Located on the right side of the anterior intestinal part, next to the stomach, is a long oval vesicle (Plate 2, Figure 6.g.) with transparent walls and containing a whitish fluid, in which brown balls are dispersed ${ }^{15}$. As a rule only one of those vesicles/ glands is present, but I have also been able to observe the presence of two, which were then located on both sides of the stomach (Plate 2, Figure 4.a.a.). I have never seen those vesicles/ glands missing. The inner and outer surface of the vesicles is smooth and the outer surface contains longitudinal and horizontal

\footnotetext{
${ }^{15}$ Strussenfelt has described and illustrated this vesicle in Holothuria phantapus first in the Abhandlungen der Schwedischen Akademie übers. B. 27. P. 268. Taf. 10. Fig. 5. of Kästner B. 27. P. 268. Taf. 10. Fig. 5 thusly: Eine länglicht kleine Blase, an Gestalt und Grösse wie eine kleine unreife Birne, liegt in der linken Seite, und ist mit dem kleinen Ende dicht unter dem Gurgelhalse angeheftet, bein dem Unterschiede zwischen der Gurgel und dem Darme. Inwendig war sie mit einer klaren Flussigkeit wie Wasser erfüllt, wobei sich ein kleiner Klumpen, dem Ansehen nach wie geronnen Blut, befand, der, als man ihn herausnahm und handthierte, bald zergieng, und einer fein geriebenen gebrannten Umbra glich.

O.F. Müller has reported these vesicles of Holothuria elegans thusly in the Zoologia Danica Vol. I., p. I: Ab annulo dependere videtur vesicula pellucidissima, ovalis, subtilissima striata; in fundo vesiculae transparet lapillus albus.

Furthermore, O.F. Müller noted the same vesicles in Holothuria phantapus a. a. O. Vol. 3 p. 55 . Vesica pendula hujus extremitatis, minor quam in pentacta, oblonga fundo rotundata et fibris longitudinalibus striata.

Finally, O.F. Müller also has described these vesicles in Holothuria pentactes without illustrating them, a. a. O. Vol. 4. p. 4. Vesica cylindrica, membranacea, tenuis, flexuosa, hinc inde coarctata et inflata, inanis, pellucida conspicitur ad latus versus partem inferiorem capitis, an vesica natatoria? In nonnullis duplex esse videtur.

These vesicles seem therefore to be found in all species of holothurians.
} 
muscles in large holothurians. Located on top of this vesicle are some fine branches of the anterior branch of the intestinal artery. The posterior end of the vesicle is blunt and ends blind. The anterior end connects into a round canal, surrounding the lower part of the mouth (Plate 2, Figure 4.h.h.). Present around the round canal are some small, hollow, brown bodies of glandular appearance, connected to which are some anterior arterial branches. Emerging from the circular or ringcanal are five branches or canals, three located at the lower and two at the upper part of the stomach, if the animal is considered in a horizontal position. The five canals or branches lead anteriorly to a calcareous ring, described later, surrounding the stomach, attached to which are five pairs of longitudinal muscles. Located on the inner surface of the calcareous ring is another circular canal (Plate 2, Figure 4.d.d.), surrounding the mouth and a part of the stomach. The five canals or branches connect into this ringcanal.

The ring canal described is in close contact with the hollow tentacular bundles and their attachments (Plate 2, Figure 4.e.e.e.e.e.). Plate 2. Figure 6.l. presents a tentaculum dissected longitudinally, to show the opening leading from the canal into the tentaculum. Emerging from the ringcanal surrounding the mouth are again five vessels (Plate 2, Figure 4.f.f.f.f.f.), which as in case of the calcareous ring emerge from the canal from between insertions of two longitudinal muscles and then run between these towards the end of the animal. These five vessels (Plate 4, Figure 8.b.b.b.b.), located between the longitudinal muscles, running from the front of the animal to the back, decrease in size, and send a large quantity of side branches to the skin and the longitudinal and horizontal muscles. The side branches (Plate 4, Figure 8.c.c.c.c.c.c.c.) end in oval, hollow globules, which are appendices or attachments of the hollow, cylindrical feet located on the ventral side as well as on the warts of the dorsal side. A number of small branches end in small canals, which contain a black colored slime.

To represent the side branches of the longitudinal muscles appropriately, I have dissected a piece of the longitudinal and horizontal muscles with all vascular canals out of the animal. This dissection is presented on Plate 4. Figure 8.C.C..

Both longitudinal capillaries (b.b.) in cross section send out side branches (c.c.c.c.), which end in the sectioned globules (d.d.d.d.). On pieces of body wall, bare of all muscles, it is possible to view the end of the globules (e.e.e.e.e.), which continue into the hollow feet.

I was fortunate to be able to fill the complete vascular system a couple of times with mercury, to assure myself of the described anatomy. I have opened the oval gland, located next to the stomach and inserted the opening of the glass cylinder filled with mercury into it. The mercury entered the posterior, round canal which surrounds the stomach with ease, and it was able to enter the canal located within the calcareous ring around the mouth, through the five previously described arms. From this canal the mercury streamed into the twenty tentacles with their attachments, which, when filled with mercury, stood erect. The mercury also entered the five longitudinal capillaries and their side branches and would penetrate into the hollow feet with their oval globules attached, which also stood erect, when mercury filled. I have also been able to demonstrate the anatomy of the vascular system, when inserting the mercury filled glass cylinder into one of the longitudinal capillaries. In this case the ringcanal around the posterior end of the stomach as well as the oval globule were also filled with mercury. The vesicle/ gland, however, would tear easily when filled with too much mercury. I have also located the vascular system, when injecting the animals with mercury through the opened tentacles or feet.

My continuous attempts to examine the vascular system lead to a very accurate description of the overall system and conclude that all parts of this system are interconnected and form a system of vessels and canals.

The previously described oval gland, the ring canal of the stomach as well as the canal surrounding the mouth, the hollow tentacles with attachments, the five longitudinal vessels and the hollow feet with their globules, contain a transparent, whitish fluid mixed with little brown dots or particles, which resemble the blood from the intestinal artery. The vascular fluid, 
however, is much more diluted than the blood in the intestinal artery. In the beginning of my studies I believed, that the oval gland, the ringcanal and all other vessels are in close contact with the vascular system of the digestive tract, but I was never able to prove such a connection. Even with the most successful injections of the intestinal vascular system with mercury, no mercury ever entered the vessels of the vascular system described. Mercury, when injected into the oval gland or the ring canal, also never entered the intestinal vascular system. The attempt to locate a connection between both vascular systems through a dissection was also fruitless. These often repeated negative attempts lead me to conclude, that the vascular system of the digestive tract does not connect to the system of tentacles, feet and skin. I therefore also conclude that the oval gland and its connecting canals, contain a fluid, which is a product of the intestinal tract secretion. The side branches of the anterior branch of the intestinal artery that form a vascular ring around the stomach and continue on the oval globule, as well as the brown bodies surrounding the ringcanal of the stomach, secrete a fluid from the blood that is dispersed into the oval gland and the ringcanal.

The oval gland shows an increased sensitivity in live, opened holothurians, as it will contract when touched, irritated with a sharp instrument or contacted with spirit. Under those circumstances the liquid contained in the gland is translocated into the ringcanal, from which it will flow in the five branches to the canal around the mouth. From there it is then translocated into the tentacles and their attachments, which will become erect. If the tentacles and their attachments contract, the liquid returns in the opposite direction back into the oval globule, which again will be expanded and liquid filled.

The function of the vascular system of the tentacles, the feet and the skin may very well be that it transports the fluids necessary to make tentacles and feet become erect and that it combines all tentacles and feet to form one system that brings uniformity into their actions. It also appears that the liquid contained in the vascular system is used to nourish the tentacles, feet, the skin and the longitudinal and horizontal muscles, even though have not found any contact between those organs and the vascular system of the digestive tract. This is the reason those parts have to be nourished in some other fashion, which can not work other than through the vascular system of tentacles, feet and skin. Part of the vascular fluid is possibly distributed through very fine branches into the parenchyma of the tentacles, the feet, the skin and the longitudinal and horizontal muscles, where it can be used to nourish those tissues. It is also possible that part of the vascular fluid is used for the secretion of the black slime, which is found in abundance on the outer surface of the skin. This black slime, which is mixed with coal, is therefore maybe the part of the fluid contained in the vascular system, which is not used for the nutrition of the animal. The loss of fluid due to secretion and nutrition, seems to be replenished by a fluid from the blood out of the arteries of the intestinal tract.

The previously described left branch of the respiratory organ, which is not connected to the intestine, but the skin musculature, increases the oxidation of the fluid contained in the main vascular system. At least I do not know of any other possible function than this.

Within the vascular system of the tentacles, feet and skin, no real circulation occurs, but only the flowing of the fluid from one side to the other. With the contraction of skin, tentacles and feet, the fluid will enter the canal surrounding the mouth, from which it will stream into the ringcanal and to the oval globule. When skin, tentacles and feet expand on the other hand, the fluid will stream into the opposite direction, through the contraction of the oval gland.

From all these examinations I am sure to be able to conclude that the holothurians possess two different vascular systems; the vascular system of the intestine, in which a circular blood flow occurs, and the vascular system of the skin with no circulation but streaming into different directions. 


\section{Structure of the Tentacles}

Each of the twenty tentacles surrounding the mouth has the form of a small cylinder, ending at the front in a broad, round surface with five or six small attachments. Located in the middle of this surface is an indentation, which gives the anterior portion of each tentacle the form of a small sucker. The tentacles are hollow and end in small, cylindrical, long appendages or processes $^{16}$ that lie within the outer surface of the calcareous ring within the body groove and end blindly (Plate 2. Figure 4. e.e.e.e.e. 6.m.). There are always as many attachments as there are tentacles, namely twenty. Located within the groove of the tentacles and their attachments is a fluid ${ }^{17}$ of the same consistency as the fluid contained within the oval globule. This fluid reaches the tentacle groove through the opening of the canal surrounding the mouth. Each tentacle has its specific opening. The second Plate (fig. 6.l) shows a longitudinal section of a tentacle in which its opening is visible.

The wider, cylindrical part of the tentaculum extending above the body surface is surrounded on the outside by a reddish-brown epidermis, which draws across the tentaculum from the anterior portion of the holothurian body. The brown color of the epidermis probably originates in the slime film covering the body surface. The attachments or tentacles located within the body groove are smooth on the surface, because they are covered with the smooth skin of the inner body. Located below the epidermis is a definite muscle layer, constructed of outer longitudinal and inner horizontal muscles. This muscle layer goes from the outer cylindrical part of each tentaculum to the inner attachment. Under the muscle layer is a third, thin skin layer, which covers the tentacular groove. Its inner surface is smooth, while the outer surface is connected to the muscle layer through small layers of cells. This innermost layer of skin is the real extension on the inside of the oval globule and the vascular canal, which surrounds the mouth.

Holothurians are able to extend and retract their muscles, which occurs in the following fashion. When expanding the tentacles, they become fully erect, which occurs due to the contraction of their processes that lead to the suction of the fluid into the anterior, cylindrical part of the tentaculum, which is now fluid filled, erect and extended. During this the oval globule will also contract which pushes some of the fluid within this vesicle into the direction of the tentacles. During retraction of the tentacles the cylindrical tentacle part will contract and will push the fluid back into the attachments and the vascular canal, surrounding the mouth. The extensions are now in a state of expansion and will be filled with the fluid. The anterior, cylindrical part of the tentacles is constricted by the contraction of the circumferencial or horizontal muscle fibers and shortened and retracted by the contractions of the longitudinal muscle fibers. This demonstrates that the cylindrical tentacular parts and the tentacular extensions are opposed in their actions and

\footnotetext{
${ }^{16}$ Bohadsch a. a. O. p. 91 described these appendages, he called them ligaments and illusrated them Tab. 7. Fig. 4, he considered them incorrectly as salivary glands as the followed section demonstrates: Usus horum ligamentorum nihilo minus valde obscurus est: cum enim altera extremitate libera sint, dentes firmare aut movere non valent; minus etiam ad cibos comminuendos aliquid conferre possunt, cum infra annulum dentium et extra cavitatem oris sita sint. An salivam secernunt, atque in cavum oris exspuunt? Sane structura atque situs eorum id non leviter indicat. Quodsi vero ita esset, praefata corpora vermiformia non ligamenta, sed canales aut ductus salivales appellanda forent.

O.F. Müller likewise described and illustrated the appendages of the tentacles in Holothuria pentactes, Zoolog. Danic. Vol. 4. p. 6. Tab. 126 fig. I; he also incorrectly held them as salivary glands as the following section demonstrates: Filamenta illa rubra mihi apparebant inserta circa ventriculum: ex eorum situ et figura immo ex structura glandulosa, structurae Appendicium circa ventricululm pisciuim non nullorum haud absimili, vasa esse succum ad cibi digestinem sublevandam continentia potius dixi, quam ut cum quibusdam facerem, vasa haec esse ovaria.

${ }^{17}$ Bohadsch also found this fluid in the appendages, a. a. O. p. 91: Quodlibet ligamentum tubulus est conicus ultra lineam crassus humore limpido refertus.
} 
a true antagonism occurs between them, because when the cylindrical parts are fluid filled and extended the extensions will be empty and contracted and vice versa. This antagonism was well studied in living animals, because the extensions, when irritated through touch with sharp instruments, emptied their fluid, while the cylindrical parts would swell and expand. If, however, the cylindrical parts were irritated, the extensions would be fluid filled and the cylindrical parts emptied.

When filling the oval gland and its vascular canals with mercury, the tentacles were also mercury filled and extended, as they are connected to the vascular system.

I have mentioned previously that the tentacles are very sensitive to touch, and will retract into the body when touched. The tube holothurian uses the tentacles to feel and touch, as well as to choose the direction in which they want to move. Due to the suckered surfaces of the tentacles they are also able to attach themselves firmly to objects and surfaces.

\section{Structure of the Feet}

The previously described one-cm long small, hollow feet, including those on the lower body surface as well as those on the upper surface, extending out of the body warts, have a high degree of similarity in their anatomy with the tentacles. They are hollow and consist of an outer tube-like or cylindrical and an inner section, which is formed like a small oval globule. On its free end the outer cylindrical part contains a sucker-like indentation, which enables the holothurian to attach themselves to surfaces. The feet consist of three layers of skin. The outermost layer is an extension of the epidermis and covers the foot from where it extends out of the original body cuticle. The second layer consists of muscle fibers, outer circular and inner longitudinal fibers. It can easily be distinguished with a magnification glass. The third or innermost skin layer is connected to the muscle fibers by its outer surface, while the inner surface is smooth and connects to the fluid filling the cavity of the feet. This skin layer can be seen as the real extension of the longitudinal vascular canal, whose side branches are accompanying the foot internal cavity. The feet connect through holes in the skin to the small oval vesicles on the inner surface of the cuticle. These vesicles, which are about $0.5-\mathrm{cm}$ long, lie within the inner surface of the skin, under and between the horizontal muscles, which they are connected to by short cellular tissue (Plate 4. Figure 8.d.d.d.d.d.d.). They consist of two layers of skin, a muscle layer, in which longitudinal and circular muscles are easily recognized by using a magnification glass, and a smooth inner skin, which connects to a side branch of the longitudinal vascular canal. The fluid contained in the vesicles and tubes of the feet, reaches the feet through the longitudinal vascular canal.

Within the foot mechanism there is another antagonism present between the vesicles and the tubes, which I have already described for the cylindrical part of the tentacles and the tentacular extensions. If the muscle layer of the tubules contracts, the tubes become constricted and are drawn into the body wall. The fluid filling the tubes will then be pushed into the small vesicles and expands them, while a part of the fluid also streams out of the vesicles and into the longitudinal vascular canal. If the vesicles contract their muscle layer, the fluid will be pushed back into the tubes, which expand, become erect and extend out of the body wall again ${ }^{18}$. The

\footnotetext{
${ }^{18} \mathrm{Mr}$. Cuvier has described admirably the movement of the feet in the Echinodermen thusly: Ces pieds rétractiles sont des espèce de suçoirs dont l'organisation est à peu-près semblable dans les trois genres, qui composent cet ordre. Chacun de ces suçoirs peut se contracter isolément. Leur forme est, à peu près, celle d'une ampoule à long tube, remplie d'une humeur très fluide, dont les parois sont formées par des fibres circulaires. La portion tubuleuse ou alongée de ces ampoules est la seule qui paroisse au-dehors de l'animal quand il a le pied alongé. Elle est terminée par une espèce de disque à partie moyenne concave. La portion sphérique est renfermée dans l'intérieur du corps. D'après cette organisation du pied, il est facile d'expliquer le mécanisme de son action. L' humeur contenue
} 
described contraction and expansion of vesicles and tubes could easily be seen in live holothurians when both parts were irritated into contraction.

The longitudinal muscles of the tubes enable the holothurians to extend the expanded, erect feet into all directions. When moving they are extended in the direction of the animals' motion.

I have studied the connection of the foot cavity with the longitudinal vascular canals, located between the longitudinal muscles, by the help of mercury injections. Successful mercury injections lead to a complete filling of vesicles and tubes with mercury.

\section{Calcareous Ring that surrounds the Mouth}

Located on the anterior portion of the holothurian body, directly posterior to the mouth is a calcareous ring, which surrounds the anterior stomach portion ${ }^{19}$ (Plate 2. Figure 4. h.h.h.). Located on the inner ring surface between the ring and the stomach, is the previously described canal, which opens into five vascular canals that lead to the ringcanal of the stomach, which is made of the vascular canal originating from the oval globule. Located on the outer surface of the calcareous ring are the extensions of the twenty tentacles.

The ring is made of ten calcareous pieces (Plate 2. Figure 5.) that are connected through a white thread-like skin and hence form a ring. There are five small and five large calcareous pieces that alternate, which means that located next to a large piece (a.a) is always a small piece (b.b) and so forth. Each of the five larger pieces is nearly quadratic and forms tooth-like edges towards the anterior, while its posterior edge seems to be slightly indented. Each of the five smaller, shorter pieces forms only one pointed structure at its anterior end but is also indented at its posterior $^{20}$. Inserted at the outer surface of the five large pieces are five pairs of anteriorly pointed longitudinal muscles. At the anterior edge five longitudinal vascular canals exert out of the canal, located on the inner surface of the ring.

dans l'intérieure de l'ampoule devient, par son déplacement, la cause du mouvement. Ainsi le pied supposé rentré dans le corps, la partie sphérique de l'ampoule cause du mouvement. Ainsi le pied supposée rentré dans le corps, la partie sphérique de l'ampoule est beaucoup plus grosse. Le pied sort-il au dehors? Les parois de l'ampoule se contractent, chassent le fluid qu'elle contient dans l'intérieur du tube, qui grossit et s'alongre. Le pied rentre-t-il? C'est alors la tunique du tube qui se contracte, et qui chasse l'humeur dans l'ampoule.

The connection of the cavity of the feet and the vesicles with this vascular system of the locomotory organ still remained unknown to Mr. Cuvier.

${ }^{19}$ Bohadsch has described the Ring a. a. O. p. 90 and illustrated it Tab. 7. Fig. 2. 3. 4: Intra cavum oris, ad initium praefatorum quinque musculorum, annulus ossens ex quinque dentibus convexo-concavis concatenatus occurrit, mediantibus duobus latis ligamentis ad ambitum oris circulariter affixus, ita ut ligamentum superius in marginem oris, inferius in oesophagi externam faciem abeat. Quilibet dens longitudine tres, et latitudine duas lineas adaequat, facie convexa cutim, facie concava, in qua ligamenta lata sita sunt, interna oris respicit. E corpore et quatuor apophysibus componitur; corpus ejus ... undulato instructus est, a quo striae exiguae versus apophyses excurrunt. Apophyses ... acutae sunt, duae laterales obtussae; mediantibus apophysibus obtusis omnes dentes adeo firmiter inter se junguntur, ut solidum annulum constituere videantur. Substantia dentium friabilis et pastae ad instar farinaceae compacta est.

Bodhasch incorrectly gives only five pieces; there are ten of them.

O.F. Müller has described the Ring in Holothuria elegans in the Zoolog. Danic.. Vol. I. p. 2 thusly: In ipsa fauce annulus articularis albus, haud obscurus; vix dentatus dici potest noster; huie introrsum annexa sunt tentacula, extrosum filamenta acuminata alba.

${ }^{20}$ GERMAN. Belon a. a. O. p. 44 says: Os in gyrum ossiculis dentatum habet, praeterea nullis ossibus alibi praeditum.

Mr. Cuvier has described this ring in his Anat. Compar. T. 3 p. 335 and this erroneous idea follows: Les holothuries ont bien l'ouverture de la bouche entourée d'un anneau, formé de dix pièces demiosseuses, mais elles servent seulement de point d'appui aux muscles longitudinaux du corps, et aux tentacules; recouvertes par la peau intérieure de la bouche et ne contenant aucune dent, elles ne servent point à la mastication. 
The disconnected and dried pieces of the ring are made of a white, calcareous, easily breakable material. I have poured hydrochloric acid over these pieces, which resulted in the destruction of the inner part of each piece, while the surrounding thin membrane remained unharmed. When I added chalky water to a part of the solution, no precipitate occurred. Adding ammonia to another part of the solution no precipitate could be reported either. However, when adding the salt of sour clover to again another part of the solution a white precipitate could be reported. These experiments lead to the conclusion that the ring is made of calcium carbonate that does not contain phosphoric acid.

The ring that is mostly made up of the calcium carbonate is obviously a basic part of the skeleton as longitudinal muscles are inserted into it.

\section{Muscles}

The tube holothurian has ten pairedlongitudinal muscles located right next to each other phenomenon $^{21}$ (Plate 2. Figure 4. g.g.g.g.g., Plate 4. Figure 8. f.f.f.f.f.). One pair of these muscles runs down the back, two pairs are on both sides of the body, and two are located on the stomach. The longitudinal muscles originate with their smaller anterior part from the outer surface of the larger pieces of the calcareous ring, always two muscles next to each other. They will then continue down the inner surface of the body wall, broadening and turning into bandanna-like, flattened stripes. Towards the posterior region of the body they will get smaller, run along the side of the cloaca, and insert themselves with their pointed end into the body wall right next to the opening of the cloaca. Located between two longitudinal muscles is a longitudinal vascular canal that originates from the canal inside the calcareous ring. The outer surface against the body wall is covered with the smooth, thin membrane that I have called the peritoneum.

The color of the longitudinal muscles is reddish-white or skin-colored. They are made out of many, closely connected muscle fibers, which are interconnected by cellular tissue. The muscles are, by the way, not very strongly curled, like the muscles in humans or mammals. If all the muscles contract in coordination-ordination the animal can shorten itself, a process during which the anterior end with mouth and tentacles and the posterior end with the cloaca shrink tremendously. The body of the animal will become much shorter bur thicker and shows a number of circular folds. If only one or two pairs of longitudinal muscles contract, the body will move to the side on which the muscles were contracting. The holothurian body can therefore be moved upwards, downwards and to the sides.

The longitudinal muscles have such great strength, that I was never able to prevent the contractions of the holothurian body while holding the animal forcefully at both ends of the body. I have often watched in living opened holothurians, that were nailed to a wooden board in order to secure them, that the contractions were forceful enough to either tear the nails out or deform them.

The spaces between the muscle pairs are filled with circular muscles (Plate 2. Figure 4. i.i.i.i., Plate 4. Figure 8. g.g.g.g.g.). They cover the whole internal surface of the animals' skin and the outer surface of the longitudinal muscles. Between the outer surface and the skin are the oval vesicles of the feet as well as the side branches of the longitudinal vascular canals, which open into the vesicles. The anterior surface of the circular muscles, which lies against the organs of the stomach region, is covered with the stomach skin.

Originating from the circular muscles are a number of threads, which are 1.5-2 cm long, and lead to the left part of the respiratory organ that they hold in place into the animals' body.

\footnotetext{
${ }^{21}$ Gunnerus also found five pairs of longitudinal muscles in Holothuria frondosa, and Strussenfelt in Holothuria phantapus. So also Bohadsch in Holothuria tubulosa and O.F. Müller in many other holothurians.
} 
Due to this anatomical feature the left side of the respiratory organ is never expelled from the body through the cloaca together with the intestinal tract. On the posterior portion of the animals' body circular muscle proportions go to the outer surface of the cloaca (Plate 2. Figure 6.c.c.) where they connect with the walls of it. This is why the cloaca is also never ejected from the animals' body with the intestinal tract and the right respiratory branch.

Contractions of the circular muscles constrict the diameter and increase the length of the living animals' body by inhibiting the contractions of the longitudinal muscles. The contractions of the circular muscles, without a doubt, also act on the oval vesicles of the feet and lead to the entrance of the fluid from the vesicle into the foot, which results in its erection and expansion. The contractions of the circular muscles may also act on the branches of the respiratory organ and the cloaca inlet, and aid the breathing out and ridding the body of excretions.

\section{Reproductive Organs}

Located next to the stomach and the anterior part of the intestinal tract is a large, branched and hollow organ (Plate 2. Figure 6.n.n.) which is constructed of a number of small branches, some blind ending ${ }^{22}$. Small branches connect to larger branches, and all of those connect at an enlarged section from which a canal leads to the anterior part of the animal. At the section, where the canal is located next to the vascular ring of the stomach, it connects to the canals of eighth, nine or ten long pear-shaped, white, 1-cm long bodies $(p$.). From here onwards the canal is located on the upper stomach surface, enters the skin and connects to an opening behind the mouth, which is hidden within a small, round circular fold of the skin (Plate 1. Figure 1.f.).

I was able to insert a fine silver sondation device into this opening of a large holothurian. I also managed to fill the branched organ, which contains a white fluid, a couple of times with mercury. I assume this branched organ to be the ovary of the animal. In some holothurians I found this organ to be two-three times its normal size at the end of October, while its branches contained long, brown bodies of different sizes ranging from $0.5-1 \mathrm{~cm}$. Those very soft bodies seemed to be eggs or even young animals. Due to their softness a further investigation was not possible. The previously described long pear-shaped, white bodies, which are hollow, and connect themselves into the ovarian duct due to their hollow interior, are possibly the male reproductive organs, or testes; but I am not able to prove this conclusion. However, in those animals in which the ovaries were enlarged in October, the white bodies also showed an enlargement to twice their normal size. The bodies also seem to be organically connected to the ovary. If those bodies are indeed male reproductive organs it would mean that holothurians are in fact hermaphrodites, animals which contain male and female reproductive organs within one body. The eggs produced in the ovaries could possibly be moved through the ovarian duct, where they would be fertilized by the sperm produced by the white bodies. I also have to mention that the ovary and the white bodies were found in all holothurians that I examined.

\footnotetext{
${ }^{22}$ Bohadsch a. a. O. de Hydra p. 86 described the ovaries without recognizing them thusly: Oesophago adnexa sunt intestinula coeca, cylindrica ultra lineam crassa, versus extremum acuminats, neo non variis punctis rubris liquori crassiusculo innatanbius, veluti vermiculis dimidiam lineam longis impraegnats.

Intestinula haec simul sumpta arbusculam aut melius fucum quercum marinam dictum quoad divisuras praesferunt; in unum truncum coeunt, qui in oesopohagum inseritur, utrum vero hic osculo quodam in eum hiet detegere nequibam. Tab. 6, fig. 6 is an illustraion.

Mr. Cuvier has described very well the ovaries of holothurians in his Anat. Compar. T. 5. p. 200: Dans les holothuries, on voit près de la bouche un bouquet de boyaux grèles très -nomereux, ramifiés, qui se développent énormément dans certaines saisons, en se remplissant d'une matiére rougeâtre et pulvérulente, qui se rassemble quelquefois en globules. Je crois que ce sont les ovaires de ces animaux.
} 


\section{Body wall}

The holothurian body wall is very thick and strong, with a thickness of about $1 \mathrm{~cm}$. The outside of the body wall has circular folds, especially, when the holothurians are in a contracted state. On the upper surface of the holothurian the body wall has large, conical warts, out of which the previously described small tubes are exerted. The body wall of the back is dark red-brown, while the stomach is more a light red-brown. The main layer of the body is similar to the leathery skin of mammals. It consists of a white fibrous, strong tissue, whose fibers weave in all directions. Between the fibers of the body wall are openings to the passages of the feet and tubules. The strong main layer of the body wall is coated on the outside with soft membrane that is easily disconnected. This upper soft membrane also coats the outside of the feet and tentacles. The color of the body wall seems to be determined by the Malphigian slime net that is connected to the uppermost layer of the body wall. The inner surface of the body wall is connected through the cellular tissue with the circular muscles. Located within this tissue are the previously described oval vesicles of the feet, as well as the connecting branches and canals of the vascular system. It is also possible to see a number of small cavities within this tissue, which are filled with a blackish-brown slime. The diameter of those cavities is about $0.5-1 \mathrm{~cm}$. A number of small canals lead from those cavities into the body wall of the animal, where they open to the outer surface in a large quantity of small openings. The slime is secreted through those openings, especially, when the animal's skin is irritated by sharp instruments or alcohol. The blackish-brown slime is very viscous and sticky and appears to be secreted in the side branches of the longitudinal canals in the previously mentioned cavities. The secretion of the blackish-brown slime, which is probably rich in carbon particles, enables the animal to rid itself of the combustible, non-nutritious parts of their food that are not excreted through the respiratory organ, as this only takes up water that will oxidize the animal's blood.

\section{Speculations about the Nervous System}

Against all odds it was impossible to find any parts that are definitely nerves of the holothurians. In animals that were stored in alcohol for an extended time, I found a number of thin threads that entered the tentacles inside the calcareous ring around the mouth and around the anterior stomach portion or behind the mouth. I have also seen some thin, fine threads of this kind within the longitudinal muscles, which extend out underneath the calcareous ring. Their fine and thin structure, however, prohibited me to demonstrate their complete connections. I have also never found a connection or swelling of nerve fibers. If the threads are indeed nerves, the nervous system seems to have an emphasis within the calcareous ring or around the anterior mouth portion. It is possible that there is a fine ring around those structures from which nerves for the tentacles, longitudinal and circular muscles originate. This would coordinate the movements of all organs. I have to admit I cannot imagine how all the numerous locomotory organs could work in a voluntary way without a nervous system. 


\title{
ESSAY
}

$\mathrm{ON}$

\section{THE STRUCTURE}

\author{
OF THE
}

ORANGE

\section{SEASTARS}

\section{ANATOMY}

OF THE

\section{ORANGE SEASTAR}

\section{$(\text { ASTERIAS AURANTIACA })^{23}$}

To examine the internal anatomy, especially the vascular system of seastar, I have chosen the orange seastar, partly due to its large size and partly because of its large population densities in the Adriatic Sea. I have also dissected Asterias rubens L. and Asterias equestris L. to compare their anatomy to that of the orange seastar.

\section{Description of the external structure. (Fifth and sixth Plates)}

The orange seastar is dorsoventrally flattened. Its middle part or body is small and leads into five rays of equal length that are located nearly in a right angle from each other. These rays become smaller towards the periphery and terminate in a point slightly tilted upward. The rays

\footnotetext{
${ }^{23}$ The first species of seastar that Rondelet wrote about and described in his article, Universae aquatilium Historia. Pars 2 p. 119, seems to be the oranage seastar. Aldrovand and Jonston have also describe this species.

Stella major aranciaca of Jacob Barrelier, in his publication, Icones Plantarum rariorum cura A de Jussieu Paris 1714 fol. Icon. 1281 Astropecten echinatus major. Lincks in his publication, de stellis marinis Lipsiae 1733 fol. pag. 27. Tabl 5 et 6 No. 6 Tab. 27. No. 44.

Described by Janus Plancus (Joh. Bianchi) in his publication of Conchis, minus notis in littore Arminiensi. Venet 1739. 4. Tab. 4. Fig. 3.

Stella marina, pentactes regularis, Barbarica. Tab 7. Fig. 2. in Seba Thesaurus Tom. 3. p. 12.

Asterias arancica junior in O.F. Müller's Zoologia Danica. Vol. 3. p. 3. Tab. 83.

Asterias arancica Linnei ed. 13. P. 3164.
} 
are of equal length in complete, normally formed and uninjured animals. I have occasionally found rays of unequal length, but it was then obvious that the smaller ones grew more recently.

The complete outer edge at the top of the orange seastar is surrounded by small calcareous pieces (Plate 5.a.a.a.a.a..) that are a gray-white-yellow color. The number of these pieces is variable and depends on the size of the individuals; small animals have fewer and large animals more pieces. On the edge of a ray of a large seastar I have counted 44 pieces; 30, 34 and so forth in smaller ones. In normal seastar each ray generally has an equal number of pieces. In animals containing one or more shorter rays I found the number of pieces on the edge to be less than on the longer rays. It was obvious that the shorter rays were newly produced in these seastar. It can generally be assumed that the rays grow through the production and addition of new pieces. A seastar that contains 44 pieces around one edge of a ray therefore contains a total of 440 pieces for all rays. These pieces, which form a row around the edge of a ray from the angle where two rays come together, decrease in size towards the end of the ray. Each of the four to five end pieces carries a thorn or spine at its top surface. All other pieces have two similar spines that are located next to each other and decrease in length towards the tip of the ray.

The complete upper surface of the body and rays, or the space between the rough calcareous pieces of the rays that carry the spines, is made of the pretty, orange, leathery body-wall of the seastar. This body wall shows the prettiest and liveliest colors in animals taken directly out of the sea. In dying animals the liveliness of these colors decreases over time and is completely lost in animals that were dried or maintained in ethanol for a while.

The orange colored body-wall contains a large number of small, calcareous, star-shaped processes. These processes have a small stalk, which is attached to the body wall by its base, and a free, nearly button-shaped end that ends in a large number of small, hard points. On large processes I have always counted thirty small spines, $0.25-0.5 \mathrm{~mm}$ in length. About twenty spines form a halo around the button-shaped end of the processes. The rest of the pointed spines are located around the middle and point towards the top. The small spines are attached to the button-shaped end of the attachments by a thin membrane. This is a continuation of the leathery membrane that covers the small stalks and attaches the small spines with the button-shaped end. The size of the processes depends on the part of the body wall on which they occur. The largest of these processes are located on the upper surface of the middle of the body from which the rays originate. They decrease in size on the rays from the middle towards the tips. The processes are also larger in the middle of the rays compared to those towards the ray edges. The complete number of these processes may be around a few thousand and varies with the size of the individual seastar. The star-shaped processes are sometimes located close together and spread apart at other times. This depends on the contractions and expansions of the leathery body-wall to which they are attached. In seastar that I had taken freshly out of the sea or kept in containers with seawater for examination, the processes were located far away from each other, and their pointed spines were extended. I was able to see the orange skin between the processes in these cases. If the seastar were kept in fresh air for a while, or irritated with sharp instruments or alcohol, the body wall contracted and the star-shaped processes were closer together. In these cases the small pointed spines were extended and formed a small bundle so that the orange skin between the processes was no longer visible. The closely bunched processes prevented that. The fifth Plate $(b$.) shows a star-shaped process with many small, extended spinelets, and in $(c$.) such a process from the side with bunched spinelets.

Located between the star-shaped processes are a number of small, one-mm long, soft, cylindrical tubule that extend from the dark-orange skin (Plate 5.x.x.x.). They show a small opening in their middle that can be seen only with the aid of a magnifying lense. The aperture 
leads through the tubule into the interior of the animal, namely into the cavity which contains the digestive stomach, the blind intestines, and the ovaries. The tubules are most abundant and longest in the middle part of the seastar, while they are shorter and less frequent on the rays. The tubules also disappear completely towards the tip of the rays. I have observed that water squirts from the tubules during slow contractions of the body wall if a seastar is taken out of the sea alive. This is why these tubules may be described as the respiratory organ through which water reaches the interior of the animal's body as I will show later on. The fifth plate $(x$. $)$ shows an enlargement of such a tubule.

Also visible on the upper surface of the animal is a flat, round, rough, stony body that is about $5 \mathrm{~mm}$ across and lies within the angle of two rays (Plate 5.m.) ${ }^{24}$ It is surrounded by an attachment. The edges of the stony body are slightly serrated and star-shaped attachments are located within the serrated edges. This stony body is attached to the body wall and on the lower somewhat hollow surface extends into a large tube, which contains a sandlike mass. The stony body seems to be present in all seastar, at least I also found it in Asterias rubens, Asterias equestris, Astropecten mesodiscus Linckii, Crossaster papposus and others.

Located in the middle of the underside of the seastar lies the mouth opening within a small cavity (Plate 6.a.) in front of which I found five hard, toothlike processes about two mm in length (Plate 6.b.b.). Each of these processes is connected to the angle formed by two rays due to their connection in the mouth area, and consists of four or five comb-like, pointed tips. These processes are movable and are definitely involved in the food uptake but not in the process of food breakdown. The reason for this is that seastars prey on molluscs, sea urchins and other animals with a hard shell that they take up through their mouth into their stomach ${ }^{25}$. Located above these five tooth-like processes is a hole that leads into a very short, wide tube. This tube ends within the body cavity in two openings located in the area where two rays are connected at an angle. Each of these openings lies next to a tendon-like band, which connects from the inner surface to the tissue to the angle. I have often observed a fine, white, folded tissue hanging out of the mouth ${ }^{26}$, which contracts and pulls back into the mouth when touched. This tissue consists of the everted esophagus and the lower part of the stomach, which seastar extend voluntarily out of their body cavity to feed.

Extending from the mouth towards the tips of the rays are five deep grooves. These grooves decrease in width from the middle to the tips, where they end. In the groove of each ray

\footnotetext{
${ }^{24}$ Link (Stellis marinis. Lips. 1733. p. 15) calls this stone-like body Verruca dorsi and describes it thusly: Fissarum stellarum plurimis vidi verrucam aliquam velut papillam, semper extra dorsi centrum intra duorum radiorum initia insidere. Papillae dictae materia dura et quasi topphacea est, ita ut ferro tacta resonet. Structura pro specierum varietate variat. Nune lentis ad instar convexa est, nunc ad cylindrum accedit. Non nunquam sinuosa ad floris speciem figuratur. Superficies erectis lamellis corrugata undosa et profunda velut pectinata est ad exemplum fere fungorum lapideorum seu Niloticorum Clusii, cui et substantia et colore similis. Manet eadem fabrica, si quae extra callum prominet superficies deteritur, excepto hoc in casu exili foramine per centrum transeunte. A parte calli interna Verruca nihil protubert, sed albae maculae instar tantum transparet, si fuerit tuba resecta, quae est inter verrucam et sphincterem gulae media.

${ }^{25} \mathrm{P}$. Belon, in his publication Aquatilibus Lib. 2. p. 382, very correctly reported in the mouth of the seastar: Os etiam versus terram ut Echini habent, in medio radiorum situm, et quamquam in gyrum quinque dentes ostendunt, tamen Conchyliorum genera cum suis testis, Tellinas, Chamas, Conchulas, Mytulos integros devorant.

${ }^{26}$ Janus Plancus (Bianchi) has reported well about the tissue protruding from the mouth of seastars in the Opusc. Instit. Bononiensis. T. 5. P. 1. p. 245: Os hujus Aninantis valde curiosum est, quando animal in aqua supinum est, et adhuc vivit; tunc enim ex ore illo circulari et cartilagineo cimmuni, quod in demortuis et exsiccatis stellis apparet, aliud os foliaceum infundibuli instar, sed veluti Lactucae folium crispatum et pellucidum emittunt. Foliaceum hoc os, et illud cantilagineum, quod magis est, ita stellae amplificare possunt, vivae dum sunt, ut Tellinas vulgares, quae non admodum parvae sint, deglutiant, uti dixi in Libro de conchis minus notis.
} 
lie two rows of long, tubular tentacles, or feet (Plate 6.c.c.c.c.c.c.). If all the feet are bent to the side a vessel ( Figure 6.d.d.) that contains a brownish-yellow fluid becomes visible. This vessel derives from a circular vessel that surrounds the mouth. It decreases in size towards the tips of the rays. The feet of both rows on a ray are paired and located across from each other, which means that one row contains exactly the same amount of feet as the opposite row. The number of feet on each ray depends on the size of the individual seastar. On a very large seastar I have counted 84 in one row, which means that there were 168 on one ray, and 840 on all five rays together ${ }^{27}$. The size of the feet does not depend only on the size of the individual seastar but also on the location where they are found on a ray. The feet closest to the mouth are only four or five $\mathrm{mm}$ long. The following feet start increasing in size and reach between nine to eleven $\mathrm{mm}$. Towards the tip of the rays the feet decrease again in size, so that the terminal feet are just about one mm long. Each tube foot has a cylindrical form that becomes conical towards the free end and exits the ray between two bulbs of the vessel. Towards the free end each foot forms a tip that contains a small brown spot. When the foot is completely extended and erect, this tip forms a round sucker that enables the animal to attach itself to its substratum. The feet are soft and coated with a smooth epithelium. During movement they are moved to one side and in the direction of the way the seastar intends to move. All feet are involved in movement, some are moved forward and attach themselves to the substratum and pull the animal's body in the direction of its movement; others are pulled in and moved forward afterwards to attach themselves also. This leads to alternation in retraction, moving and attaching the feet. The feet are very sensitive and irritable as they will be retracted into the groove when touched or irritated with a sharp instrument ${ }^{28}$.

Located on the previously described, rough, calcareous pieces on the edges of the rays are other hard, rough and calcareous horizontal pieces (Plate 6.e.e.e.e.e.) separated by small grooves that nearly reach the grooves in which are located the feet. Visible on the lower surface of these horizontal pieces are rows of pointed thorns or spines that are extended out diagonally and forwards. These can be extended and adducted. The first and totally outwardly extended spine of these horizontal pieces is the longest (Plate 6.f.f.f.f.). Its length differs between the different locations of the pieces on the rays. The spines connected to the angle between two rays are the longest, approximately four $\mathrm{mm}$ in length. The remaining spines decrease in size towards the tip of the rays. In addition to these longest spines, four to five shorter spines also are attached to the horizontal pieces that decrease in size towards the groove. These shorter spines are also larger in the wider part of the rays and smaller on the tip. Seastars are able to lift and move their bodies with the help of these articulated spines.

\footnotetext{
${ }^{27}$ Reamur, in the Mem. de l'Ac. Des Sc. Anné 1710 p. 486, described and wrote about the feet thusly: Chaque rayon de l'Etoile est fourni d'un si grand nombre des jambes, qu'il n'est pas étonnant q'elles le couvrent presque tout entire du côté où elles lui sont attachées. Elles y sont posées dans quatre rangs differens, chacun des quels est d'environ 76 jambes, c'est-à-dire que chaque rayon en a 304, et par consequent l'Etoile entire est pourvue de 1520 jambes nombre asses merveilleux, sans que Bellon le poussat jusqu'a près de cinq mille etc.

I have not found four rows of feet in any species of seastar, on the contrary always only two rows. The number of feet reported by Reaumur is too large.

${ }^{28}$ Belon, a.a. O. Lib. 2. p. 338, has described the movement of the seastar: Vagantur in mari ut Polypi, brachia diducendo, nunc ante gradiendo, nunc in orbem convolvendo, et suctu acetabulorum, echini modo, lapidibus adharent. Sensu tactus eassnon vacare comperiet, qui manum ferream conto infixam ad eas attolendas immerserit. Ad bas enim contactas plenius moveri et fugam tentare experietur.

Also Reaumur, Mém. De l'Acad. des Sc. Ann. 1710. p. 487.

J. Baster, Opusc. Subseciv. p. 117, und Janus Plancus (Bianchi), Opusc. Instit. Bonon. T. 5. P. 1. p. 244, have described the movement of the seastar.
} 
Aside from these spines a number of small, flat, round and hard processes (Plate 6.g.g.g.g.) are visible on both edges of the groove in which the feet are located. These processes can be retracted or adducted towards the feet. When the seastar are walking and the feet are extended, the processes are extended away from the feet with their round end facing the surface. However if the seastar are not moving and the feet are retracted into the groove, these processes are adducted against the feet. These processes can cover the feet and the grooves completely by laying themselves over the feet to protect them.

The whole lower surface of the rays is, by the way, covered by numerous small, rough ridges or tips, which take up the space between the previously described thorns or spines. Some of these tips are always located between two feet and seem to aid their movement.

The orange seastar can vary in size between 29.25 and $58.5 \mathrm{~cm}$ in diameter. This difference in size leads to the assumption that seastars live for a number of years. Large seastars always possess more feet and thorns than small ones, which leads to the assumption that they do not only grow by the growth of body parts already present, but also by production of new parts or sections.

I have maintained living seastars in large, seawater-filled wooden containers in my apartment to study their habitat. I will explain the observations I have made about these animals here. When taken directly out of the water the seastar moved their feet in all directions and retracted them when touched. The body wall contracted and water squirted out of the previously described tubules. As soon as the seastars were returned to the water-filled container they slowly started to extend and move their feet. The body wall and the star-shaped appendages also were extended. I have observed in seastars, maintained in a smaller, shallower containers covered only by $1.625 \mathrm{~cm}$ of water, slowly extend and contract their body wall. This leads to increased water movement, especially around those body parts where the previously described tubules are attached. I think it is likely that water was taken up and expelled due to the expansion and contraction of the body wall, which caused the swirling water movements due to the movement of the water into and out of the tubules.

When moving, which is caused due to the movement of the feet, the mouth is turned toward the substratum. On a level surface seastars were able to walk fairly quickly, while they moved slowly when on a surface with uneven parts, such as large stones. When walking the tips of the different rays will point in the direction of the movement. With the help of the feet they also test the surface on which they walk. The animals are able to move their rays closer together or spread them further apart, so that the angles between two rays can get more or less acute. The movement of the rays towards and away from each other depends on the habitat and surrounding area in which the animals move. I have often observed that animals in aquaria that contained a large stone that would inhibit their complete extension would move two rays in the direction of their movement. These two rays would also be brought closer together by the animals. Animals in this fashion were able to move through a small space, defined by two large stones, after a couple of tries. Seastars can also move their rays upwards and even up and turned to the inside. This was also a very common movement of the rays when the animals tried to move through a confined space. Seastars do not only crawl on level but also on perpendicular surfaces, as I observed animals to crawl up the side of the containers in which they were maintained

A seastar placed upside down on the back so that the mouth and the feet point upwards will not remain in this position very long, but will turn their body into its normal position. This occurs by tilting the tip of one or two rays downwards towards the bottom of the container and attaching themselves with the feet of those rays to the container bottom. It then will turn its body and make it stand perpendicular in the water and slowly turn it round so that the mouth and the 
feet are located on the bottom once more. I have repeated this experiment a number of times. The orange seastar, Asterias rubens and Asterias equestris are unable to swim, or at least I have never managed to observe this behavior.

The seastar rarely survived in a container in which the water was not exchanged for two days. If, however, I exchanged the water on a daily basis I was able to maintain it for many days. The water that contained the seastar would cloud during the first day and I would find empty shells, which they had expelled through their mouth, on the bottom of the container. In water that became cloudy due to a seastar, the movements of the feet would slow down. If irritated, it still contracted slowly. The color of the body wall would also become less lively. Soon the body wall and the feet would lose their ability to react to irritation, and especially the feet would hang lifeless from the animal when taken out of the water. Finally the seastar would no longer show any vital signs, the rays would break easily and decay started. The dead seastar showed a strong phosphorescence at the night.

I have sometimes turned a small container with shallow water and a small seastar so that half of it was covered from the sunlight. However, the animal always seemed to move in the direction of the sun. It therefore appears that it can sense the light without having eyes, which may mean that they can feel it.

The seastar appears to be a very tough animal. The feet maintained movements and irritability twelve to fourteen hours after I opened some individuals and removed their stomach and blind intestines. I also observed this in individual rays that $I$ had separated from the rest of the body. Seastars also seem to be highly irritable to galvanic stimuli. The feet showed strong contractions when I either touched them with both poles of a long galvanic tube or when I laid one pole on the body wall and the other onto the feet.

I do not doubt that seastar have the capability to regenerate, which means that they are able to newly produce one or more broken or lost rays. I have maintained a few seastars that had one or two very small rays that had definitely been produced very recently ${ }^{29}$.

The orange seastar is very common on the sandy bottoms of the Adriatic Sea, and possibly in the rest of the Mediterranean and other warm seas.

\section{Mouth and blind intestines (Plate 7.)}

The round mouth opening is surrounded by a white, soft and somewhat folded epidermis that is very easily stretched so that seastar can take up whole molluscs with their shells into their

\footnotetext{
${ }^{29}$ Reaumur in the foreword to the sixth volume of his Memoires pour servir à l'histoire des Insects, page 61 says the following on the capacity for regeneration: Ils (M. Bernard de Jussieu et Guettard) virent des étoiles, et m'en apporterent qui n'avoient que quatre grànds rayons égaux, et un cinquiéme encore naissant; ils ne trouverent d'autres à qui il n'etoit resté que trois grands rayons, et qui en avoient deux extrêmement petits; d'autres qui n'avoient que duex grands et anciens rayons accompagnés de trois très-petits et probablement très-jeunes. Enfin ils virent plus e'une fois un grand et seul rayon, du quel quatre petits commencoient â sortir. La pitié ne sembloit donc pas exiger qu'on se fit quelque peine de mettre des étoiles en pieces, aussi ne furent-elles pas épargnées. Des pecheurs qui remarquerent que M. de Jussieu le coupoit et les déchiroit, lui dirent qu'il auroit beau faire, qu'il ne parviendroit pas à leur ôter la vie: ils étoient accoûtumés à voir une reproduction dont les Physiciens n'avoient pas même soupconné la possibilité. Les parties en les quelles Mrs. De Jussieu et Guettard avoient divisé chage ôtoile, leur parurent se porter bien, ils virent leur playes se cicatriser et se consolider; mais il n'e leur fut permis de rester sur la côte qu'environ une quinzaine de sours, temps trop court pour suivre le progrès d'une reproduction qui selon les apparences, n'est complette qu'après plusieurs mois, ouo peut-etrê après plus d'une anneé.
} 
mouths. The mouth opening leads into a very short and broad esophagus that then leads into the round stomach. The stomach (a.a.a..) is located in the middle of the body and is round and voluminous. In the middle of the outer surface of its upper part are two small, somewhat contorted blind attachments (b.b.). Originating between these attachments is a small, white, perforated reticular epidermis $(c$.) which forms a funnel towards the inner surface of the middle of the body wall and inserts into it. This epidermis is connected to the white fibers of the actual body wall. This funnel-shaped epidermis from the inner body-wall surface suspends the middle part of the stomach in the middle of the body and also attaches it to the inner body-wall surface.

A number of white, strong fibers, two to four mm long, originate from the outer and upper surface of the stomach. They have a tendon-like appearance and attach to the inner surface of the body wall. These fibers actually are continuations of the white, shiny, tendon-like but contractile tissue of the body wall. All these fibers connect the outer surface of the stomach and the inner surface of the body wall and suspend the stomach within the body cavity. There are ten rows of these fibers, two from each ray. Long, white, tendon-like fibers that lead into the ray cavities also originate from the lower surface of the stomach. They run underneath the first part of the blind intestine and connect to the white, tough, tendon-like membrane that connects the bulbs of the rays and keeps them together. Two fibers lead into the cavity of each ray. Each of these fibers is composed of four or five smaller fibers that come from the stomach and soon merge to form one strong, dorsally flattened fiber. This fiber inserts into the upper surface of the tendon-like tissue below the blind intestine and between the bulbs of the feet. This body wall connects the bulbs of one ray. The end of the fiber usually inserts in a larger form into the body of the tenth, eleventh, twelfth and thirteenth bulbs of a ray. (Plate 8.z.z._.) ${ }^{30}$.

\footnotetext{
${ }^{30}$ [Anne: This is the first paragraph of this footnote and needs translation.] Diese so eben beschriebenen, weifsen, sehnenartigen Faden hat ein anfangender Naturforscher in den [Anal. Du Museum d'Histoire naturelle. T. 13, p. 439] [Do not translate the preceding] bei der Untersuchung der Asterias rubens irrig fur Nerven gehalten, uknd als das Nervensystem beschrieben und abgebildet. Pl. 32. Fig. 3. 6. In die Beschreibung des vermeintlichen Nervensystems haben sich folgende Irrthumer und Fictionen eingeschlichen, die ich hier so anfuhren will, wie ich sie bei wiederholten Zergliederungen der Astterias aurantiaca, der A. rubens, des Astroopecten mesodiscus Linkii und der A. equestris gefunden habe.

This gentleman says on p. 440: Entre la membrane tendineuse, et derrière les petits prolongemens en forme de coecum, produits par le reserrement de l'estomac globuleux, précisement vers la réunion des deux vaisseauz hepatiques et au-dessous, sont placés duex nodules grisâtres, qui ressemblent à un grain de mil un peu allongé.

[Anne Translate] Dies graue Knotoen oder Ganglien, welche der Herr hier beschrieben und sogar abgebildet hat, existiren durchaus nicht, ich habe sie niemals gefunden, auch selbsst bei den grossten pomeranzfarbenen Seesternen nicht.

The gentleman says: Les nodules de chaque rayon communiquent entre eux par un filet, qui part de l'un pour se fixer à l'autre. [Anne. Translate] Einen solchen Verbindungsfaden habe ich niemals angetroffen. Further on he says: Deux ou trois filets se portent de chaque nodule à la face supérieure de l'estomac, et s'anastomosent entre eux et avec ceux des autres ganglions; la remuscule extérieure se replie sur le lobe hépatique de son coté.

GERMAN: ....: Un filet se dirige de chaque ganglion vers le rayon voisin; arrivé à moitié chemin, il descend par un peti trou du bord osseux entre le sillon longitudinal et la saillie intermédiare des rayons, puis il se ramifie autour de la bouche, et peut-ètre même dans la membrane extèrieure du corps.

GERMAN

The gentleman says further: Le plus considérable de tous ces rameaux et le plus long, est celui qui sort de chaque nodule sous le lobe hépatique, entre le sillon longitudinal et les deux rangées des tentacules; il fournit un filet à chaque tentacule, et diminue ainsi de grosseur, à mesure qu'il approche de la point du rayon. GERMAN

GERMAN
} 
The stomach is constructed $\mathrm{f}$ a fine, thin, nearly transparent dermis, which is possibly made of several tissue layers. However, due to the fine structure of this epidermis it was impossible to separate the tissue layers. Its outer surface is smooth and shiny and seems to be covered by some form of stomach tissue. White fibers, which are webbed, are clearly visible in the walls of the stomach. These fibers appear to be muscle fibers. The fibroid appearance of the stomach can be observed most clearly under a magnifying lense. These fibers are also visible when a piece of stomach is help up to the light. The esophagus and the lower part of the stomach, which can be everted out of the mouth, clearly contain a layer of light-red fibers that are mostly longitudinal fibers. The inner surface of the stomach, primarily of the upper part, is velvety, ruffled and forms serpentine foldings. The inner surface of the epidermis contains many folds that merge at the mouth when the stomach is empty. Only few folds are visible when it is full and stretched. I observed five branched, very fine vessels at the upper surface of the stomach, whose branches run together in a middle of the body (Plate 7.d.d.). These observations have been made without the aid of a magnifying glass. Under the microscope I have also observed a large number of very small vessels that seem to be located between the inner velvety and the outer coarse muscular layer.

The stomach in a living animal displays sensitivity and irritability as it contracted when irritated with sharp instruments or alcohol. The starting or lower part of the stomach displays a higher degree of sensitivity than the upper part. Having observed the fine structure of the stomach it is nearly unbelievable to imagine that seastar swallow molluscs, sea urchins and other seastars alive and with their full shell ${ }^{31}$. I will list here the different prey that I have found in the stomach of different orange seastar to prove my previous statement. The stomach of one seastar contained seven molluscs of the genus Strombi and one Terebra. The soft parts of these animals were fully digested but the shells had not been touched by digestion. The stomach of another seastar contained a number of Dentalia. In the stomachs of three animals I have, to my greatest astonishment, found very large Murices with all their spines. One of these molluscs was $6.5 \mathrm{~cm}$ in length and $4.875 \mathrm{~cm}$ in width, and still the stomach walls never showed any spine penetration. The size of these molluscs shows that the stomach has to be immensely flexible, and that even the rays will have to expand to expand the mouth opening. Sometimes I have also found bivalve

Finally he says: notre assertion nous parroit beaucoup plus juste lorsque nous considérons l'anatomie de ces filets. Trois membranes constituent constamment leur structure; la première est très dure, et presque blanche dans plusieus endroits, ce qui lui donne l'aspect de fibres tendineuses; la second est plus molle et grise; la troisième, la moins consistente, est toute entière dela même couleur.

GERMAN

${ }^{31}$ Aristoteles, Part. Animaliuim Lib. 4. Cap. 5. says incorrectly: Stellarum etiam genus simile est: quippe quod concharum complures aggrediens exugat

Likewise incorrect is Meinung Aelians in his publication natura animalium Lib. 9. C. 22. Cum testacea suas patefaciunt conchas, vel cum refrigeratione egent, vel ubi aliquid pertinens ad victum incidit, eae uno de suis cruribus sive radiis intra testas ostrei hiantis insito, eas claudi prohibenthes, carne explentur. Reaumur a. a. 0. p. 486 errs when he says: On voit au milieu de l'étoile, lors qu'on la regarde par dessous, une petite bouche ou succoir, dont elles se servent pour tierer la substances des coquillages des quells elles se nourrissent, comme Aristote l'a fort bien remarqué - il es certain qu'elles mangent les Coquillages, et au'elles ont autour leur succoir cinq dents, ou plutôt cinc petites fourchettes d'une espece de matiere ossuese, par le moyen desquelles elles tiennent les Coquillages pendant qu'elles les succent.

TRANSLATE THE GERMAN FOLLOWING.

Also Rondelet, Piscibus Lib. 4. C. 2. p. 83. Quod alimentum duriuis esse potest marinarum cochlearum testa plane saxea? At stellarum est genus, quod illis alitur saginaturque. Liebet hic referre quod unacum multis, qui mecum erant, vidi Stellam vix pedem unum longam in litus projectam, non procul a Magalona dissecui, in cujus tres integras, duas alias emollitas et semi coctas inveni. 
molluscs such as Cardia, Tellinae, Donaces, Veneres, and others in the stomach of a seastar. The animals were always more or less digested but the shells were never scratched in any way. This leads to the conclusion that seastars do not really possess any teeth that are used to crush or mash the food. In the stomach of a large seastar I have found a sea urchin of the genus which was named Spatangus by Mr. Lamarck. This sea urchin was $6.6 \mathrm{~cm}$ in length and $3.65 \mathrm{~cm}$ in width. The fine spines were mostly still attached to the animal's test, but some of them had already fallen off. In the stomach of yet another seastar I have found a small seastar of the genus that is called Asterias equestris. Its rays had softened extensively and already had started to fall apart. I have also found small fishes amongst the stomach contents of some seastars. Sometimes I also discovered a large piece of carbon and some mollusc shells within the stomach of a seastar. The carbon was practically squared, $3.55 \mathrm{~cm}$ in length and $1.0 \mathrm{~cm}$ in width. This proves that the seastars do not possess a very fine taste and that they are animals that will consume anything that they can get hold of.

The seastar feeds in the following fashion that I have sometimes observed frequently when I maintained individuals in seawater containers. If their stomach was not filled completely, which can easily be detected from the outside as the upper and middle parts of the body are sunken, they evert their esophagus and lower stomach part. Those parts of the digestive system are characterized by a white, folded tissue that comes out of the mouth opening ${ }^{32}$. With the help of this stomach part they search for food and hold it by the help of the feet. They then start to invert the food through the mouth opening together with the stomach. This leads to the rays expanding on all sides to enlarge the mouth opening. I have also observed this eversion of the stomach in animals whose stomach was already full. The filling of the stomach can easily be identified by the slight bulging of the upper middle part of the skin under which is located the stomach.

The soft and dissolvable parts of the molluscs, sea urchins and seastar taken up through the mouth can be digested in the stomach. The indigestible parts of the animals taken up are expelled through the mouth, as seastars do not possess an anus ${ }^{33}$. The digestion of food probably occurs due to the work of a stomach enzyme similar to that of other animals that is produced by secretory cells of the stomach.

Located in the middle of the outer surface of the stomach's upper wall are two hollow, somewhat twisted appendages of the stomach (Plate 7.b.b.) that possess the same structure as the stomach, just thicker walls. These appendages are in connection with the stomach through a small opening. I was able to blow up the stomach through the attachments and vice versa. These

\footnotetext{
${ }^{32}$ The eversion of the stomach is also described in Mülleri Zoolog. Danica Vol. 4. p. 13 thusly: Cum animal hoc vorax praedam pedibus sive tentaculis tubulosis membranaceis arreptam et retentam commedere studet, eamque majorem devorare nequit, membranam ventriculi instar ex ore protrudit, fortasse ut succo quodam corrodent ex had profluente praedam necet et concoctioni aptiorem reddat. I have never found such a corrosive fluid in the stomach.

33. Baster GERMAN Asteriadibus sive stellis marinis in his Opuscul. Subseciv. p. 116. GERMAN structure of Asterias rubens and incorrectly reported an anus for them: utrumque (genus Echinorum et stellarum marinarum) os inferne et ad excretements ejicienda sperturam superne habent.

Also Janus Plancus (Bianchi) has made the same mistake in his Epistola de incessu marinorum Echinorum ac de rebus quibusdam aliis marinis ad Ferd. Bassium in his Opuscul.. Instit. Bononiensis T. 5. P. 1. p. 245 when he says: Praeterea hae Stellae anum in medio oppositum ori, uti Echini, veluti umbilicum quemdam gerunt et in acumen attollunt.

Rondelet, Piscibus marinis. Pars 2. Insectis et Zoophytis Liber. Cap. 10. de Stellis marinis p. 118 says very correctly: Excrementorum nullus exitus apparet. Ore igitur Urticarum more excerni quae supervacua sunt, arbitror.
} 
appendages contain a whitish fluid. It is possible that these appendages simply contain the excretions of the stomach.

Originating from the side walls of the stomach are ten long, branched, intestine-like blind attachments ${ }^{34}$ that I shall call blind intestines. Two blind intestines are located in the cavity of each ray next to each other. Each blind intestine is attached to the inner surface of the body wall, covering the cavity of the rays from above, by a fine, white, transparent tissue. This tissue, or tendon, forms some sort of mesentery (Plate 8.s.s.). The branched blind intestines do not stretch all the way into the tips of the rays, but only take up two thirds or three quarters of each ray. This means that for example, the blind intestine of a $22.5 \mathrm{~cm}$ long ray measure $14 \mathrm{~cm}$.

[Anne: The second sentence is incomplete.] Jeder Bilnddarm entspringt mit einem kukrzen, einige Linien langen, rohrenformigen Theil (Taf. 7.e.e.e.e.e.), der gegen zwei Linien im Durchmesser halt, aus den Seitentheilen des Magens. Der rohrenformige Theil lauft durch den ganzen Blinddarm, enger werdend, bis zur Spitze hin. An diesen Theil, welcher gleichsam den Stamm des Blinddarms bildet, sind an abeiden Seiten die in einen rechten Winkel entspringenden Seitenaste befestig.

Each blind intestine originates through a short tubular part, a few millimeters in length and two $\mathrm{mm}$ in diamter (Plate 7.e.e.e.e.e.) From a side part of the stomach. The tubular section runs through the complete blind attachment and becomes smaller in diameter towards the tip. Attached to this part, which can be considered as the base of the blind intestine, are the two side branches that ariseat a right angle. Located on each side of both the side branches are six to eight hollow branches or bladders. The number and size of these side branches depends on the size of the individuals. I found 40 side branches leading from an intestinal stem in a large individual, but only 28 to 30 in a small one. I concluded from this that the number of side branches increases with age. I have also found smaller numbers of side branches in those animals that had one or two newly produced rays. Two of the blind intestines are shown from their upper side (Plate 7.f.f.) as well as from both sides (g.g.).

The lower surface of each blind intestine contains a small, long, hollow appendage that usually contains a yellow fluid. This appendage is possibly some form of secretory organ. Two blind intestines are shown from their lower side (Plate 7.h.h.) and with their appendages (i.i.).

The spacious blind intestine connects to the stomach and the stomach cavity continues into the intestinal cavity. It is therefore easy to inflate the blind intestine through the stomach and vice versa. The inflated blind intestines (Plate 7.k.k.) are very spacious and wide and cannot be considered to be any organ other than an intestine.

If a blind inestine is dissected longitudinally from its stem, two openings become visible that are located next to each other and lead into the side branches. Plate 7 (l.l.) shows two ventrally dissected blind intestines.

\footnotetext{
${ }^{34}$ Kade, Stellae marinae Holsaticae Anatome in Lincks publication, Stellis marinis p. 101 has described this attachment thusly: Porro in utroque radii latere viscus laciniosum, arbusculam quoddam modo referens, cuti ope membranae annexam, in icone ab ea avulsam exhibetur fig. 2. c. An intestina?

Mr. Cuvier GERMAN that the organs described by Kade are blind intestines. In his Anat. Compar. T. 4. p. 143 he has described it thusly: La cavité alimentaire, en forme de sac compliqué, s'observe dans les astéries ou étoiles de mer; c'est un sac membraneux, très-plissé quand il est vide, situè au centre commun des branches, et ne s'ouvrant qu'à la bouche, de sorte que les excrémens n'ont pas d'autre issue. Ce sac a dix appendices ou boyaux aveugles extrémement subdivisé en branches et en ramaux, et formant à l'oeil des expèces d'arbres très-agrèables à voir. Ils sont logés dans les branches du corps, deux dans chaque branche; quand l'astérie a plus de cinq branches, alors il y a aussi plus de dix arbre de coecums. Ces arbres, ou ces espèces de grappes, sont fixés dans leur place par des mésentéres membraneux.
}

GERMAN 
The walls of the blind intestine of the orange seastar are yellow-white, very fine, thin and torn easily. Their outer surface is smooth; their inner surface folded. It was possible to distinguish a large number of white longitudinal and horizontal fibers with the help of a good magnifying glass. These fibers are possibly muscle fibers. The blind intestines are hardly irritable in a living seastar, and only contract slightly when irritated with a sharp instrument or some alcohol. I will describe the vascular system of the blind intestine when I illustrate the complete vascular system.

I usually found the blind intestine of the orange seastar filled with a gray-white fluid, similar to milk fluid or chylus. It has no particular taste and forms a gray-white precipitate when diluted with water. I have never found undigested parts of the food, such as mollusc shells, which are taken up through the mouth opening.

\section{Respiratory organ}

The previously described soft and cone-shaped tubules located on the upper surface of the body wall are the respiratory organs of the seastar ${ }^{35}$. Each hollow tubule is connected to the body wall between the star-shaped appendages by its base. The walls of the tubules are muscular and contain light-red circular muscles. The small opening located at the tip of the tubule, which can only be located by the help of a magnifying glass, leads to the cavity of the tubule. This cavity connects to the body cavity of the seastar without forming vessels or canals in the center of the body. It was impossible for me to fit the small steel tubule attached to the mercury-filled glass cylinder into the aperture of the respiratory tubule. This is why I have separated the whole body-wall at the edges of the seastar and have folded it from the inside out into a funnel-shaped cavity. I have then filled this cavity with mercury. When applying pressure to the folded body wall the mercury entered the tubules and exited out their tips. From this experiment I concluded that the tubules end freely in the body cavity of the seastar. Their internal apertures located within folds of the body wall are made out of white, contractile fibers that I shall describe later.

The water entering the body cavity through the apertures at the tips of the tubules washes along the walls of the stomach and the branched blind intestines. It also comes in contact with vessels, which I will describe later, that are suspended in the body cavity. When dissecting a living seastar taken out of the water, a larger or smaller quantity of water can be found within the body cavity. The function of the water taken up into the body cavity seems to be none other than to oxygenate the digestive fluid or chylus, contained within the blind intestine and the venous blood circulating in the vessels. There is no doubt that the branched, leafed structure of the blind intestine will aid the influence of the water the animal ingested with the chylus. This occurs due to an enlarged surface area the water will touch. This leads to an increased oxygenation of the

\footnotetext{
${ }^{35}$ Reaumur, in a discussion of these papulae of Asterias rubens in the Mémoires de l'Acad. des Sciences Ann. 1710 p. 490 has described them very well thusly: On auroit p avoir dû avoir penchant á regarder les jambes des Etoiles, comme les parties dont elles se servent á respirer l'eau, á cause de la ressemblance qui est entre leur figure et celle des tuyaux charnus des autres poissons dont nous avons parlé. Les Etoils n'ont point de si gros tuyaux pour servir à cet usage; c'est de quoy elles sont dedommagées par une quantité prodigieuse de petits tuyaux, dont toute leur peau est remplie. Lorsqu'on prend des Etoiles en certains tems où elles sont fort gonflées par l'eau, on voit bien vite l'effet de ces tuyaux, en appercevant une infinité de jets d'eau très-déliez qui sortent partout de leur peau. Mais si l'on regarde alors avec attention l'Etoile, on voit que chacun de ces jets part d'un petit tuyau peu sensible à la vûe, qui le devient pourtant d'autant plus qu'on l'oblige de sortir davantage en pressant la peau de l'Etoile auprès de l'endroit oû on l'remarqué. Il paroit de figure conique, et d'une couleur blanche.
} 
chylus. The branched structure of the blind intestine therefore seems to be closely related to the respiratory process.

The water uptake occurs due to expansion of the body wall and the resulting increased intake of water into the hollow tubules and the body cavity. Exhaling the water, on the other hand, is done through the contractions of the irritable skin and the muscular tubules. During this process the water is squirted out of the tubules as described earlier. It was impossible for me to identify how often the changing expansions and contractions of the body wall take place within a certain time frame. I have already discussed the fact that seastar cannot survive in old seawater which was not renewed.

\section{Blood vascular system of the intestine}

Running within the two plates of each blind intestine foldings is a very thin skinned, white vessel (Plate 8.a.a.b.b.b.b.b.b.b.), which contains a white fluid and a small branch from each branch of the intestine (Plate 8.a.a.). The vessels start with their finest branches on the inner surface of the skin of the tip of each ray. They then increase in size and lead into a larger vessel, which runs circularly around the inner surface of the body wall of the seastars (Plate $8 . d . d . d . d . d$. and penetrate through five bands (Plate 8.e.e.e.e.e.e.e.) that run from the inner surface of the body wall towards the mouth angle. As there are ten blind intestines, there are also ten vessels which lead into the circular vessel. Due to their fine walls I considered these vessels as blind intestinal veins. They probably transport the venous blood away from the blind intestine and also take up the chylus or nutrient-rich fluid. This can be assumed due to the facts that:

1. I have never found any other vessels around the blind intestine which could be absorbing capillaries, though not from lack of trying.

2. The fluid contained in the previously described vessels is very similar to the chylus contained within the blind intestine.

Several times I have been able to partly fill the blind intestinal veins with mercury. Complete filling of all branches of the blind intestinal vein has never been achieved as the mercury tore the fine and fragile walls of the vessels.

Aside from the ten blind intestinal veins which lead into the circular vessel, there are also white vessels coming from the ovaries that also lead into it. Each ovary sends out one vessel. As there are ten ovaries, there are also ten ovarian veins. These veins (Plate 8.c.c.c.c.c.c.c.c.c.c.) lead into those parts of the circular vessel where it penetrates through the five bands of the inner body surface. Located on the surface of the stomach are five white, very thin-walled, and branched vessels (Plate 7.d.d., Plate 8.g.g.) that come from the stomach periphery and lead towards the middle of the stomachs upper surface. They lead into two other vessels that run through the hollow inner-tissue band that runs through the body in the angle in which the stone canal and another vessel are located. This other vessel will be described later. I called these vessels stomach veins due to their thin walls and assume that they also, like the veins of the blind intestine, take up the nutrient-rich fluid from the stomach cavity.

The ten blind intestine veins, the stomach veins, the ten ovary veins and their circular vein stem are filled by the seawater which enters the body through the previously described tubules. . The seawater possibly oxygenates the fluid contained in these vessels and turns it into arterial blood.

The ring canal of the inner body wall forms only a large vascular stem within the band described. This stem leads into a long, widened vessel that is located next to the stone canal 
within the cavity of the band. The stone canal will be described later. The vessel (Plate $8 . k$.), into which the stem of the circular canal ends, is about $3.25 \mathrm{~cm}$ long and $0.3 \mathrm{~cm}$ in diameter in large animals. It has a brown color and is made of finely webbed yellow-brown fibers that show a similarity to muscle fibers. Its outer surface is smooth. Its inner surface, which is washed by the fluids that are transported to it through the ring canal, has a net-like appearance. I have repeatedly managed to fill the ring canal and the vessel described with mercury. The vessel slowly narrows into a funnel shape and leads into the stem of a vessel that leads towards the mouth and turns into vessel that will be described later into which the stone canal ends. In a living dissected seastar the brown vessel displays irritability when irritated with sharp instruments or alcohol. When irritated it contracts, though weakly and slowly.

I consider this canal to be some form of a heart, because:

1. the stem of the ring canal, into which veins of the blind intestines, the stomach and the ovaries lead, terminate in it;

2. it becomes funnel-shaped again on the other side in a stem of a vessel;

3. it forms an extension;

4. it is made of yellow-brown fibers that show similarities to muscle fibers; and

5. it is contractile in a living animal.

The stem of the veins therefore leads into the heart-like canal and into the arterial stem.

The vessel originating from the heart-like vessel (Plate 8.l.) runs along the stone canal towards the mouth opening and underneath the ring canal that surrounds the mouth. After this the vessel turns towards the bottom of the animal and forms a vascular ring (Plate 9. fig. 1.a.a.) around the mouth. This vascular ring is covered by the thin outer epidermis of the mouth as well as by an orange vessel. Only after I had dissected out the hard, tooth-like attachments around the mouth and taken out the outer epidermis of the mouth and the orange vessel was it possible to see the vascular ring. Originating out of this ring are five branches that lead into the cavity of the seastar over openings across the tooth-like attachments and form small branches that end in the stomach, the intestines and the ovaries. It is possible that the smaller branches are in contact with the veins of the stomach, the intestines and the ovaries. Such a connection, however, could not be proven due to the fine walls of the vessels that made a mercury injection impossible. I considered the vessel originating from the heart-like canal, as well as the vascular ring surrounding the mouth, to be arteries that transport arterial blood to the previously described parts. I have managed to fill the canal and the vascular ring with mercury a number of times.

In addition to the previously described vessel, another orange-yellow vessel (Plate 6.d.d.) can be observed at the lower surface of the seastar. This vessel surrounds the mouth in a circular fashion and sends out a branch into each groove of each ray between the two rows of feet. This vessel becomes smaller towards the tip of the ray. I have never been able to show a connection with the previously described vessels and am therefore unable to determine if the vessel represents an artery or a vein. The function of the vessel therefore also remains unknown to me.

The description of the connection and distribution of the vascular canals in the orange seastar does suggest that a blood circulation exists in the fashion that I have previously described. The fine and fragile nature of the vessels made it impossible to experiment with the circulation of the blood, which is the reason why I cannot add physiological observations to my anatomical ones. The previously described system does not have vessels going out to the feet, bulbs or rays. It therefore seems that, as in the holothurian, it only connects to the stomach, blind intestine and ovaries. Aside from this vascular system there is another one connected to the feet, bulbs and rays that will be described now. 


\section{Vascular system of the feet, bulbs and rays}

If I took out the blind intestine of a dorsally opened seastar and cut out the stomach at the mouth opening, four rows of oval, hollow and fluid-filled bulbs that are connected to the feet became visible. In addition to them (Plate 8.t.t.t.t.t.) I also located pear-shaped vesicles on a long stem in the area where two rays are connected (Plate 8.q.q.q.q.q.). These vesicles are three to four $\mathrm{mm}$ long and contain a light, transparent liquid. The stems of these vesicles, which are also hollow, connect to a larger stem that opens into a ring canal, located at the beginning of the rays. This ring canal (Plate 8.n.) is hidden underneath a tendon-like tissue that covers and connects the articulation of the rays. In the seastar that I used in the Plates, I have found seventeen of the pear-shaped vesicles. I occasionally found 18 or only 15 or 16 . I always found five large, hollow stems or canals only that connected to the smaller stems or canals of the hollow vesicles. These five larger stems insert and open always into the ring canal that surrounds the mouth. They connect where two rays join in an angle.

In the seastar that Linck named Astropecten mesodiscus I have found only five larger, pear-shaped vesicles that connect to the ring canal. Such stemmed vesicles could also be located in Asterias rubens and equestris and therefore seem to be common in all seastars.

The long, pear-shaped, hollow vesicles that are filled with a light, transparent liquid, which have not been described prior to my description as far as I know, are smooth on the outside, and surrounded by light-red muscle fibers. Their inner surface, which is washed by the inner fluid, is smooth. In vivo these vesicles display irritation to touch with sharp instruments or alcohol. They always drew back when irritated, contracted and pushed the liquid they contained through the stems or canals into the large stems and from there into the canal surrounding the mouth. I have repeated this experiment and constantly found the same result.

Located on the inner surface, where the larger stem or canal inserts into the ring canal, are two small, round, brown and ventrally flattened bodies that are scarcely one to one and one-half $\mathrm{mm}$ in diameter (Figure 8.o.o.o.o.o.). These bodies have a gland-like appearance and consist of small, round, visibly hollow sacs that resemble the gland vesicles. They are hollow and easily filled with mercury. Each of these gland-like, hollow bodies opened via a round aperture into the ring canal. Ten of these bodies are located in pairs opposite the five stems of the pear-shaped vesicles. It seems very likely that these gland-like bodies secrete the light, transparent liquid that is contained in the ring canal and the bulbs. This is possibly transported through smaller vessels that come from the main artery surrounding the mouth on its lower surface and enter the gland-like bodies, but I have been unable to observe this due to the fine structure of those vessels.

Another large canal, containing an easily crushed, stony or sandy mass, also ends in the ring canal around the mouth. I shall call it the stone or sand canal. This very peculiarly large and wide canal ${ }^{36}$ comes with a wide base from the lower surface of the round and somewhat angular

\footnotetext{
${ }^{36}$ Linck a.. a. O. S. 15 called this canal Tuba verrucae and described it thusly: Tuba dicta colore candida, vix lineam per diametrum maximum, qui est ad verrucam crassa, sensim gracilescit, et incurvata super annulum sceleti mediuim, spincteri gulae connascitur, ita ut verruca pressa, extremitas tubae opposita per gulae orificium veniet in conspectum (This is not correct). Constat tuba membrana tenui et nervea, cui includitur materia friabilis, stridens, quasi e testarum, grosso modo contusarum, pulvere compacta. Quae cujus gratia adsit, cum nec ad gulam, nec ad verrucam exitum detegere possim, me ignorare ingenus profiteor.

Mr. Spix, in his Mémoire on the history of the red seastar Asterias rubens L. etc. in the Annal. Du Muséum d'hist. Natur. T. 13. P. 446, likewise reported this stone canal and incorrectly held it was an organ analogous to the penis of the snail! He described it thusly: á la face supérieur du corps, près de la réunion de deux rayons, un seul tubercule spongieux et rond, dont l'intérieur est concave et renferme deux canaux
} 
stony piece located on the upper surface of the seastar between two rays. This also forms the base of the canal and is clearly connected to it. The canal runs from the stony body downwards into a cavity that is made of two tendon-like folds coming from the inner surface of the of the upper body wall (Plate 8.i.i.). These folds run down the angle that connects two rays as a sickle-shaped band. The stone canal is up to $6.5 \mathrm{~cm}$ long in large animals and decreases in diameter and takes up a serpentine appearance around the ring canal. It connects to the ring canal between two of the gland-like bodies. I have repeatedly found the connection between the stone canal and the ring canal in over 40 animals. The walls of the stone or sand canal are white, strong and smooth from the outside, while folded on the inside.

The stone canal is filled with a sandlike, easily crushed yellow-white mass similar to the chalk-like pieces around the edges of the seastar body. This sandy mass always contains fluid, which moves from the ring canal into the stone canal. The mass is probably produced in the stone canal and can be considered as nutrition for the pieces and the chalk pieces on the outside of the animal's body. It consists of a carbonate and phosphate rich chalk as shown by a chemical analysis. When dissolving the mass in sulfuric acid a strong gas production was noted. An addition of oxalic acid to one part of the mixture caused a strong precipitation. Addition of calcareous water to yet another part of the solution caused a slight cloudiness.

The ring canal surrounding the mouth, which contains the ends of the hollow stems of the pear-shaped vesicles that I described previously, the ends of the brown gland-like bodies and the stone canal, has a very thick, tendon-like, smooth wall. Coming from this fluid-filled canal are five radial canals for the five rays. Each radial canal enters the ray in the middle of the combined row of the articulations and decreases in size towards the tip of the ray. On both sides of the radial canals smaller branches arise that lead between the articulations into the hollow tube-feet and the previously described bulbs that can be observed after excision of the blind intestine. There are as many side branches as there are feet.

The following examinations have convinced me of the inner connection of the pear-shaped vesicles, the stems, the gland-like bodies, the stone canal, the ring canal, the radial canals and the hollow tube-feet and their bulbs: I have opened a pear-shaped bladder and inserted the steel tubule of the mercury-filled glass cylinder. The mercury moved from the pear-shaped vesicles through its hollow stem into the larger stem and from there into the smaller stems of the pear-shaped vesicles that were consequently filled with mercury. The mercury also filled the ring canal, the hollow stems and the bulbs. After that the stone canal and the gland-like bodies were supplied with mercury. Finally the mercury even entered the radial canals and smaller branches, the feet and their bulbs, when the steel rod of the glass cylinder was inserted into the ring canal, the stone canal or one of the feet or one of their bulbs. I also have opened a pear-shaped vesicle and pumped up the whole system with air through a fine rod. During that process some of the vesicles were always filled with the air. I have been able to fill the feet and the bulbs of a ray with air $^{37}$ when I inserted the rod into a radial canal of a ray.

entortillés; l'un est gélatineux et blue, l'autre spongieux et blanc. Le premier s'insere près le bord osseux dans le second, qui, de son côté, descend veres le cou de l'estomac et s'ouvre en dehors. La situation et la figure de cette partie a quelque rapport avec le pénis des limaces.

Mr. Spix GERMAN

${ }^{37} \mathrm{An}$ investigation GERMAN $\quad$ a. a. 0. 101. §. 12.: Praeterea vesiculae humore turgidae vertebris impositae, numero et ordine papillis respondeut, in illasquae terminantur; vel papillae sunt continuatae vesiculae et vice versa. Distenduntur quippe ambae si per certum canalem flatus impellitur.

$\S$. 13. Experimentum sic instituitur. Integer amputatur radius quicunque; cutis cum annexis visceribus prope aculeos reciditur, ut totus vesicularum tractus pateat; nunc quaeritur orificium canalis, quod nullo 
All these experiments showed that all the organs described are internally connected so that they form an organ system I shall call the vascular system of the rays and feet.

The question now is the function of this vascular system. I shall answer that question in the following way: The vascular system, filled with a light, transparent fluid that is probably secreted from the fluid of the vascular system into the gland-like bodies, is the same as I have already described for the holothurians. The liquid, in vivo, is transported by the contractions of the muscular walls of the pear-shaped vesicle into the ring canal. Out of this it streams through the radial canals into the hollow feet and their bulbs. In this way the feet and their bulbs receive the fluid that they require to move. The fluid also seems to nourish the pieces and spines of the rays, as it receives a chalk-like mass from the stone canal. The chalk-filled fluid flows through the walls of the stone canal into the pieces. This opinion is supported by the following:

1. I have never found vessels which lead into the rays or branched only in them;

2. I have found the calcareous mass from the stone canal to have the highest degree of similarity to the mass of the pieces.

I have never found a true circulation within this vascular system but more a directional streaming due to the contractions of the pear-shaped vesicles. Through these contractions the fluid is pushed through the radial canals from the ring canal into the feet. During the contractions of the feet, part of that fluid streams in the reverse direction through the radial canals and the ring canal back into the pear-shaped vesicles.

I have to remark that I have also found the described vascular system in Asterias rubens, Asterias equestris and Astropecten mesodiscus.

\section{Tube feet and their bulbs}

I have previously documented the number and position of the feet and shall now explain their structure and vital signs. Both rows of the feet of one ray come out through small holes located next to the bodies and attachments of the calcareous pieces of one ray. The first section of each foot is cylindrical in shape; the terminal section becomes conical and terminates in a pointed end about one $\mathrm{mm}$ in length. During attachment the pointed end is modified into a round sucker or plate. The outer part of the pointed tip shows a brown coloration. Each foot continues through the hole between the attachments of two pieces into the cavity and forms two oval bulbs. If a ray is dissected from the aboral surface and the blind intestines are taken out, it is then possible to see four rows of paired reddish-white, oval bulbs that decrease in size towards the tip of the ray ${ }^{38}$. The size of these oval bulbs corresponds to the size of the feet, which means that a large foot always leads into two large bulbs while a small one ends in two small ones.

The feet and bulbs are hollow and contain a light, clear fluid. They are covered externally by a fragile, smooth epidermis that connects to the holes through which they protrude. Located below this epidermis is a light-red, circular layer of muscular fibers that reaches nearly to the tip of the feet and also covers the bulbs located within the rays' cavity. The cavity of the feet and bulbs is covered by a smooth membrane, washed by the clear fluid that is present in this cavity. The fluid reaches the feet through the radial canals of the previously described vascular system.

\footnotetext{
negotio sub prima vertebra inter membranam communem, quae cornua investit et illam, quae vertebris immediate incumbit, detegitur; per hunc canlem tubuli ope flatus intrusus vesiculas omnes, et si animal recens omnia cornua expandit.

38 The presence of these four rows of oval bulbs may have lead Reaumur a. a. 0 . to the wrong conclusion that seastar also have four rows of feet in each ray.
} 
Each foot with both its bulbs is only connected to one radial canal that transports the fluid. I have mention at this time that I have observed fine, white, spiral threads when I pulled out a food with the help of a fine pair of tweezers. These threads were located between the layer of circular and longitudinal muscles and could carefully be uncoiled.

In vivo the bulb and feet are highly irritable and sensitive as they contract when touched or irritated with a sharp utensil. The feet and bulbs display the same antagonism as described in the holothurians. When the bulbs are irritated into contraction the fluid that fills them is pushed into the feet, which increase in length and stand erect due to the fluid. However, when irritating the feet into contraction, the fluid streams into the opposite direction towards the bulbs, which expand and become fluid filled ${ }^{39}$. The antagonism between contraction and expansion of feet and bulbs leads to the ability of localized movements in the seastar. During movement the feet are expanded, fluid-filled and erect, while the bulbs are empty and contracted. If the seastar does not move and the feet are drawn back into the grooves of the rays, the bulbs are expanded and fluid filled. The forward and sideways movement of the feet is controlled through the contractions of the longitudinal muscle fibers.

I have found the same anatomy of feet and bulbs in Asterias rubens, Asterias equestris and Astropecten mesodiscus Linckii. I have also observed that they have the same function as in the orange seastar.

\section{Skeleton}

The basis of body and rays of the orange seastar is formed by mobile rows of articulated pieces. These pieces are yellow-white and very solid, so they can not easily be ground between two fingers. They are made of calcium phosphate and calcium carbonate, and perhaps magnesium, as chemical analysis has revealed. A strong bubbling occurs when a few pieces are dissolved in sulphuric acid. Addition of the salt of oxalic acid to a part of the solution led to a white precipitate. Addition of acetic acid to another part of this solution caused a strong precipitation. Addition of ammonium to yet another part of the solution led to a weak precipitation. The addition of carbonated water to the rest of the solution caused another precipitation. I concluded from these results that the pieces are made of the same material as the mass in the stone canal. This supports my previous hypothesis that the pieces are nourished by the sand out of the stone canal.

Each ray has a small vertebral column made of a row of vertebra-like pieces that decrease in size and strength from the proximal to the distal tip of a ray (Plate 8.C.). The vertebral columns of all five rays are connected by their first vertebral pieces around the mouth, where their sides lie next to each other in pointed angles. The first vertebra of each ray is particularly large. The number of vertebrae in a ray depends on the size of the seastar. I have counted 85 vertebrae in a ray of a very large orange seastar, and 425 on all five rays combined. In small individuals I have found $80,76,70$ or only 60 vertebrae. The number of vertebrae is the same in each ray in animals which have never been injured and lost a ray. If seastar has, however, lost parts of one or more rays, which have partly been regenerated but are shorter, the number of vertebrae is lower in the regenerating ray then in the normal rays. These rays therefore partly

\footnotetext{
${ }^{39}$ Reaumur a. a. 0 . has quite correctly described the function of the feet and bulbs that lie next to the spine $\mathrm{p}$. 489: Ces boules possées se déchargent de leur eau dans les jambes qu'elles gonflent et ètendent qussi-tôt; mais des-lors que l'Etoile cesse de presser les boules, le ressort naturel des jambes qui les affoise, les raccourcit et chasse l'eau dans les boules don't elle etoit sortie.
} 
grow through addition of new vertebrae at the tip of a ray, partly through addition and enlargement of the individual vertebrae. This has been observed by comparing vertebral columns of old, large and young, small individuals.

Each vertebra is made of two pieces ${ }^{40}$ that originate from the middle of the vertebra and are connected to each other by rough edges. These edges can be seen clearly if a vertebra is separated into two pieces. Each piece can be differentiated into a body and transverse processes. The bodies of the vertebrae extend into the cavity of the ray. It is broader then long. Its upper protruding surface has a small indentation and its undersurface has a deep groove which contains a side branch of the previously described ring canal that surrounds the mouth. Located on each side of the body is a horizontal process (Plate 8.C.v.v.) that starts out small and then broadens. The front edge shows a small projection or process that connects to the back edge of the transverse processes of the previous vertebra. The back edge also shows a projection or process that is much wider and larger than the front one and is connected to the front edge of the transverse processes of the following vertebrate. These projections or processes that connect diagonally with each other on the vertebrate can also be called diagonal processes (Plate 8.C.w.w.) as they resemble the diagonal attachment of the mammalian vertebrae. The connection of the vertebrae enables the rays of an animal to show sidewards movement. Located between the thin part of the transverse processes is an oval, longitudinal slot (Plate 8.C.x.x.) for the entry of the foot that leads into the oval bulbs lying within the depression of the horizontal transverse processes of two vertebrae.

Connected to the outer end of each horizontal process is a small, long, calcareous piece (Figure 8.C.y.y.). Attached to this piece on the ventral surface of the rays are larger calcareous pieces that have thorns or spines. On the underside of the horizontal processes is a small, oval piece, which shows some irregularities, to which the flat, round connect [Anne. I don't understand the preceding.] that cover the feet, when they are drawn back into the trough of a ray. THIS NEXT PARAGRAPH IS PARTICULARLY CONFUSING

Connected to the outer ends of the small, long pieces, attached to the horizontal processes of the vertebrae, are the calcareous pieces that carry the thorns or spines, as I have just described, that lie on the underside of each ray. Each of these ventral calcareous pieces is strong, drawn out longitudinally and carries four or five small, rounded lined protuberances on its underside, to which the thorns or spines attach. Each thorn or spine has a groove or depression at its articulation end that matches these rounded protuberances. The attachment of this depression of the spine with the rounded protuberance is made by a tendon-like contractile tissue. This attachment enables the movements of the thorns or spines on the calcareous pieces. Attached to the upper surface of each calcareous piece is an upper calcareous piece, which becomes visible dorsally on the edge of a ray. Each of these pieces carries another one or two thorns on its upper surface as I have previously described. The five tooth-like processes, which partly cover the mouth from below, are connected to the tip of the vertebrate that is formed by the connection of two rays.

All vertebrate and all parts of the skeleton are connected through the body wall (cutis) as I will show later on.

I shall now give an overview of the number of the different parts that make up a ray and the whole body of a very large, complete and intact orange seastar.

The numbers of the parts that form the body of a orange seastar:

\footnotetext{
${ }^{40}$ As Kabe has already correctly reported a. a. O. p. 101: Vertebra constat ex duobus ossiculis p. 102: Haec duo ossa, ubi se contigunt, formant in supina parte fornicem; hic situs est canalis, per quam flatus impellitur, pro tentamine§. 13.
} 
each of the 85 vertebrae of a ray is made of 2 pieces I shall call vertebral pieces

small longitudinal side pieces of the vertebrae, 85 on each side

calcareous pieces, to which are connected the that protect the retracted feet

processes that cover the feet from below, only two on each calcareous piece

lower calcareous pieces that carry the thorns or spines, 44 on each side of a ray

thorns or spines on each calcareous piece, only four counted

upper calcareous pieces on the edge of the rays, 44 on each side of each ray

thorns on the upper calcareous pieces, 2 on each piece counted

tooth-like processes around the mouth sum of all skeletal parts

added to this 2500 star-shaped processes on the body wall

number of feet

number of the oval bulbs

sum of all skeletal parts, star-shaped processes, feet and oval bulbs

\begin{tabular}{|c|c|c|}
\hline \multirow[b]{2}{*}{ tha } & 1 ray & all 5 rays \\
\hline & 170 & 900 \\
\hline & 170 & 900 \\
\hline rocesses & 170 & 900 \\
\hline $\mathrm{n}$ & 340 & 1700 \\
\hline es, & 88 & 440 \\
\hline & 352 & 1760 \\
\hline on & 88 & 440 \\
\hline ce & 176 & 880 \\
\hline & 1 & 5 \\
\hline & 1555 & 7925 \\
\hline$y$ & 500 & 2500 \\
\hline & 168 & 840 \\
\hline & 336 & 1680 \\
\hline feet and & 2559 & 12945 \\
\hline
\end{tabular}

If I would then also add the spinelets on the processes, of which there are 30 on each, the number of parts of a seastar would be much greater than six thousand.

The large number of individual parts that form the body of an orange seastar is amazing. It is generally a characteristic of the radial animals to form a regular animal out of a large number of individual pieces. The organic mass that forms the large number of regular parts of these animals seems to be used in higher animals to form different organs.

\section{The body wall}

The body wall of the orange seastar contains white, tendon-like, shining, strong, thick fibers, webbed in many directions that form the leathery body wall. The thick and strong leathery body wall is covered externally by a thin epidermis that can easily be dissected away. When cutting off this layer, the colored part of the body wall, a kind of Malpighian slime net will also be taken off as it is connected to the upper skin.

In vivo, the body wall is very irritable. When it is irritated with a sharp instrument or alcohol it contracts visibly. I have often dissected the body wall of living seastars from the calcareous pieces on the edges of the rays. The body wall would always contract horizontally.

Located between the net-like webbed fibers of the body wall are small spaces that lead into the trachea-like tubules and into the body cavity. The water necessary for respiration enters 
the body through these tubules. The spaces between the body wall fibers are displayed (Plate

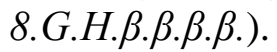

Originating from the inner surface of the middle part are a large number of white, thin threads that lead to the stomach walls suspended in the body cavity. Also originating from the same surface are five strong, nearly sickle-shaped bands. These are located in angles formed by the attachment of the rays. These sickle-shaped bands (Plate 8.e.e.e.e.e.) end on the upper surface between the first articulations of each ray. One of these bands is folded and forms a large cavity that contains the stone or sand-canal and the heart-shaped canal (Plate 8.i.i.).

Connected to the epidermis that surrounds the body and rays on the outside are the bases of the star-shaped appendages. The epidermis divides at the edges of the rays into two layers or plates, a thin, outer and a thick, inner layer. The thin, outer layer covers the calcareous pieces of the edge and underside of the ray and connects them to the ray articulations. By covering the calcareous pieces the outer layer attaches the thorns or spines to these. The in vivo irritability of this epidermis explains movements of the thorns on the calcareous pieces. The thorns will become erect when the body wall is contracted and laid down when it expands. This is done in the same fashion that mammalian skin muscles move the hairs on their skin through contraction and expansion. The inner, thicker layer of the body wall covers the pieces of the vertebrae and connects them to the vertebral column. Different degrees and directions of contractions of the body-wall parts aid seastar in vivo to move their rays into different directions. They can move their rays up, down and in diagonal ways and can bring rays closer together and further apart. The fact that these movements are brought about by the irritability of the body wall is demonstrated by the absence of the muscles that I have found in the holothurian.

\section{Ovaries}

The orange seastar has ten ovaries ${ }^{41}$ located in the five angles of the body next to the stomach and the blind intestine on both sides of the five sickle-shaped bands that move down the angles. Each ovary is made of a number of bundles, about twenty, connected to the inner surface of the body wall (Plate 8.a.a.a.a.) and lying below against the oval bulbs. Each bundle generally has four branches. About eighty round, light-yellow vesicles are found on each branch. These vesicles are hollow and contain a gray-yellow fluid. I have repeatedly opened a branch and injected mercury, which led to the filling of all the vesicles of that particular branch and even of the next branch with mercury. As I have never found an opening ${ }^{42}$ I assume that the eggs will rupture from the vesicles during reproduction. They will then exit the body through the previously described holes in the angles of the rays that open to the outside close to the mouth

\footnotetext{
${ }^{41}$ Kade has very correctly described the ovaries his a. 0 . p. 101: His remotis (intestinisi), in angulis, quos radii formant, duo alia (in quolibet scilicet radii latere unum) corpora laciniosa parva pyramidalia fere libere pendent fig. $2 \mathrm{~d}$.

Baster has described them thusly in Asterias rubens in his Opusc. subsecivis p. 118: Sub jam memoratis intestinis, ad utrumque etiam Spinae latus, duo reperies ovaria, Martio, Aprili et Majo mensibus ovis minutis flavescentibus referta, aliis vero temporibus, albae pinguedinis speciem habent.

Mr. Cuvier has likewise described the ovaries in his Anat. Compar. T. 5. p. 199.

${ }^{42} \mathrm{Mr}$. Spix wants, certainly, to have found an opening in Asterias rubens a. a. 0. p. 445: Les ramucules sont composés de vesicules et abontissent à un grand canal, qui court le long des ovaires et s'ouvre près de la réunion des deux rayons. L'ovaire n'étant fixé aux parties environnantes que par son canal, it est libre dans tout le reste de son étendue. J'ai gonflé toutes les vesicules en soufaltn dans le canal commun et par le même moyen j'ai reconnu l'ouverture extérieure. - I have found this opening in no species of seastar.
} 
above the tooth-like appendages. I observed that the ovaries contain branches of arteries and veins that I have described previously in the vascular system.

When dissecting seastars at the end of September or beginning of October, the egg-shaped vesicles were very small. In animals dissected at the end of October these were then very large and fluid-filled. I therefore assume that reproduction of the orange seastar takes place in the fall and that the vesicles and eggs detach from the ovaries during that time.

I have never found any other organs that could have been identified as male reproductive organs in any of the more than one hundred seastars that I dissected ${ }^{43}$. Seastars therefore seem to be only female and produce fertile eggs that do not appear to need the influence of any male reproductive fluid.

\section{Nervous system}

After dissecting out the orange-yellow vessel that surrounds the mouth and sends a vascular canal that runs between the feet to the tip of each ray, I located a white thread in very large seastars (Plate 9. figure 2.a.a.a.) that surrounds the mouth in form of a ring. This ring is located on the outer surface of the canal that originates in the heart-shaped canal and which also surrounds the mouth. This thread sends out two smaller threads that decrease continuously towards the tip in each ray (c.c.). Two smaller threads (b.b.) also originate at the part of the ring where the threads are sent out to the individual rays. These threads enter the oval hole located between the first and second vertebrae on each side. They might be associated with the stomach. It often appeared as if the thread leading into the ray, located between the feet, send out smaller branches to the feet. I therefore consider this ring including the originating threads as the nervous system. I have to state that I have never found any ganglia. The nerve ring around the mouth obviously co-ordinates the actions of all rays that would not be possible without a nervous connection.

\footnotetext{
${ }^{43}$ Baster says a. a. O. p. 118: Die Echinorum et Asteriadum coitu aut generatione, quod dolet, nihil certum scio. Mensibus vernis, omnium, quos videre licuit, ovaria ovis turgida sunt: sexus distinctionen observare non licuit. An ergo sunt Hermaphroditi?
} 


\section{ESSAY}

On

THE STRUCTURE

OF THE

STONE SEA-URCHIN 


\section{ANATOMY}

\section{OF THE \\ STONE SEA-URCHIN}

(ECHINUS SAXATILIS $)^{44}$

I have not been able to obtain in Triest for observations of the internal structure any larger kind of sea urchin than the stone sea-urchin which is very common on the rocky shores of the Adriatic Sea. The small size of this sea urchin made examinations of the internal anatomy difficult, but I believe that I was able to recognize most internal parts correctly.

\section{Description of the internal structure}

The actual body or the calcareous test of the stone sea-urchin, to which the spines are attached, is round and dorsoventrally flattened. The upper and lower surfaces can be identified by the orientation of the animal in the sea and by its movements. The lower surface contains the mouth opening; the upper, the anus ${ }^{45}$.

The middle part of the lower surface is made of a soft membrane, which does not contain spines. This soft membrane closes the opening of the animal's test that will be described later. Located in the middle of this membrane is the mouth. Protruding from the mouth are the tips of the five strong teeth.. These are surrounded by the soft, brown, round membrane, which forms a small, lip-like fold at the edge of the teeth. The membrane is contractile in a living animal, and the animals can expand and contract it.

Visible at a short distance from the mouth opening are ten small, protruding, cylindrical, soft tubes (Plate 10. Figure 5.b.b.b.b.) that surround the membrane and are about one mm long when extended. Each of these short tubes has a round surface at its free end, which contains a small depression in the middle. These sucker-like attachments enable the animal to attach itself to the substrate, as I have observed often. I assume the animal also uses these tubes to locate and hold on to the food, which is then cut up by the teeth and taken up by the esophagus. Live animals are able to extend and retract these tubes.

${ }^{44}$ This species also has been described as Echinus ovarius by Rondelets in his Schrift de Piscibus Lib. 18, p. 578. Gefaner de Aquatilibus p. 416 and Mr. Aldovand de animalibus exsanguibus Lib. 3. de testac. p. 402 . Seba Thesaur. Tab. 12. Fig. I. Cidaris miliaris saxatilis J.T. Kleins in his Naturalis dispositio Echinodermatum. ed. N.G. Leske Lips. 1778. 4. p. 12. P. 82. Tab. 2. A. B. C. D. Tab. 31. A-D. Tab. 38. F. 2. 3. Echinus saxatilis Müllers in his Prodomus Zoologiae danicae 2817. Echinus miliaris Linék's in his Systema Naturae ed. 13. T. I. p. 3169.

${ }^{45}$ Aristotle, Hist. Animal. Lib. 4. Cap. 5. describes the location of the mouth and the anus quite correctly thusly: Contigit autem a natura echinis, ut quod in ipsis caput dici solet itemque os ima in parte subtus habeant, excrementi autem exitum in suprema: idque evenit cum turbinatis omnibus tum patellis. Pascuntur enim ab humo: ergo os quidem ad pastionem in 
The other part of the membrane that closes the lower opening of the test contains a large number of two-mm long burrs ${ }^{46}$ (Plate 10. Figure 5.c.c.c.c.). These have a button-shaped end that is made of three sections. The tips are located close to each other, but can also be spread apart. Such organs are also located in large numbers between the tubefeet and spines, but they are much smaller than the spines. The small size and sensitivity of the burrs made it impossible for me to determine more about their organization and function. In the beginning I assumed that they were organs analogous to the respiratory tubules of the seastar. However, as they are attached to the membrane and do not penetrate it into the body cavity of the animal, I had to discard this assumption.

Located where the membrane that closes the lower body opening attaches to the edge of the test are ten bundles of hollow, soft tubules (Plate 10. Figure 5.d.d.d.d.). Each of these tubules has an opening at its free end that that leads into the body cavity. The large openings of the tubules lead into the body cavity of the animal next to the calcareous pieces to which the teeth are connected. I succeeded a number of times in inserting small spines or probes through the tubules into the body cavity (Plate 10. Figure 3.c.c. shows the ten openings of the tubules from the inside). The hollow tubules transport seawater into the body cavity that can always be found within an sea urchin. These tubules are therefore analogous to the respiratory tubules of the seastars.

The whole surface of the animals from the edge of the membrane to the anus is covered with spines. The spines on the lower surface closest to the membrane are very short, only a few millimeters in length. Towards the side they are longer, about eight to nine $\mathrm{mm}$. Such longer spines are also located on the aboral surface of the sea urchin. Those arranged around the anus are again shorter, about four to five $\mathrm{mm}$. Located between the long, protruding spines are many smaller spines that are only two mm long. Their color can show variation between different sea urchins. I have found them to be dark-brown, green-brown, dark-purple and green. Even though there is a color variation between individuals, the color of these secondary spines is always the same within one individual. At least I have never found two colors in one individual. Each spine has a club-like appearance. The base has a small depression that fits onto a protuberance from the test. The depression and protuberance are connected by a small tendon-like tissue that is contractile in life. From the base the spine then becomes more pointed. The whole outer surface shows longitudinal black lines. I shall talk more about the number and type of articulation of the spines to the test. Sea urchins are able to move their spines up and down. These movements are brought about by the contraction of the tissue between the spines and the test.

Between the spines of the living sea-urchins that are taken directly out of the sea or maintained in a container with sea water, a large number of soft, red-brown, cylindrical tubules can be seen. At their free end these tubules contain a round suction cup that shows a small depression in its middle. I shall call these tubules tentacles or feet. They are always one to two-mm longer than the spines and therefore protrude farther during the local movement of the sea urchin. The length of these feet also depends on their location on the sea urchin. The shortest feet are found on the underside surface of the test where the spines are also the shortest. The longest feet on the other side are located with the longest spines on the side of the sea-urchin test.

\footnotetext{
${ }^{46}$ Baster also seems to have known these appendages in the Opusc. subseciv. p. 114: Proboscidum omnium extremitas non eodem modo formata est. Plures sunt, ut in figura expressi, sunt et quaedam, quarum extremitas tribus quasi cuspidibus terminatur.

Alex. Monro has described and illustrated similar appendages in Echinus esculentus. Tab. 33. Fig. 18. 19. 20. 21. in his Vergleichung des Baues und der Physiologie der Fische mit dem Bau des Menschen und der übrigen Thiere, translated from English by J.G. Schneider. Lepzig 1787. 4. p. 88
} 
Located on the upper surface, close to the anus, are short feet. The sea urchins can move quite fast when they are undisturbed in the sea water. When they are taken out of the sea water the feet are drawn back between the spines ${ }^{47}$ so that they are no longer visible. This also happens when the feet are irritated in sea water with a sharp instrument. These feet have been found to be very sensitive and irritable.

Located in the middle of the upper, convex surface of the test between the spines is the anus, surrounded by a number of small, calcareous pieces or small plates. When the spines closest to the anus are removed five small holes that lead into the ovaries become visible

I have maintained a large number of stone sea-urchins in wooden and porcelain containers to watch their behavior. What I have observed on these animals will be explained in the following paragraphs. The sea urchins, after they had been placed in the containers, erected their spines and extended their feet, which they moved actively. The animals moved on the bottom of the containers with the mouth next to it. They touched their surrounding area with the help of the feet and examined their direction of movement. After that they attached to the container by their extended feet, retracted the other feet only to extend them forwards and attach them too. The animals did not only move on the bottom but can also on sloping and perpendicular surfaces. They moved onto stones that I had put into the tanks as well as the walls of their containers. The suckers on the tip of the feet attached the animals strongly to the different surfaces and a certain amount of power was necessary to detach them. The spines did not appear to aid in movements but remain extended.

When I turned the animals onto their upper surface so that the mouth was directed upwards, they did not remain in this position. They turned their spines towards the bottom of the container and used them as levers to turn their body around ${ }^{48}$. The feet were also extended and started to attach to any surface to right the body onto the midsection followed by the ventral surface. After righting, the animal continued to move in its normal manner. I have often inserted sea urchins between two stones, where they also used their spines to change their position to one where they can use their feet. Therefore the spines are not really organs for movement but more as aids to movement. The real organs for movement are the feet or tentacles ${ }^{49}$. When the sea

\footnotetext{
${ }^{47}$ P. Belloniuis de aquatilibus Lib. 2. p. 386. Promuscides autem Echinorum edulium linguis Cicadarum vel muscarum similes sunt, stellarum et udendorum marinorum modo, easque tan crebres habent, ut dinumerari nequeant, quibus undique circumsepti adhaerescunt: extrorsum autem non apparent: concidunt enim in se ipsos contracti.

${ }^{48} \mathrm{As}$ P. Bellonius also has already reported: Echinus minor est reliquis omnibus vividior: Nam si supinum ponas, mox suss spinas deprimit, et se in pronam partem convertit. Plures habet quam alii proboscides: idcirco citius repit, firmiusque haeret.

${ }^{49}$ Aristotle Hist. Animal. Lib. 4 Cap. 5. Motu maxime et agili et frequenti moventar esculenti (Echini): cujus rei argumentum praebent, quod aliquid semper spinis sublatum gerunt.

- Spinis autem quasi pedibus, his enim innixus et movetur et mutat locum.

- Gandolphe has correctly noted that the sea urchins do not move with their spines but with the tentacles or feet. See his Histoire de l'Acad. des Sciences Année 1709 p. 33. Les Naturalistes crooyent, que les Epines dont les Oursins sont herisés leur tiennent lieu de Jambes, et qu'ils s'en servent pour marcher. Mais $M$. Gandolphe ayant observé à Marseille ces animaux, qui marchoient assez vite au fond de la mer, a découvert que ce ne sont point leurs Epinnes qui executent ce mouvement, mais des Jambes disposées autour de leur bouche, qui est toujours tournée contre le fond de la mer, ces Jambes disparoissent entiérement, des que les Oursins sont tirés du fond de l'eau, et dela est venue l'erreur commune. On a su qu'ils marchoient et on n'a point vu leur Jambes, parce qu'on ne les a point vus marcher dans la mer. Elles ressemblent à celles d'un Insecte plat, nommé Etoide de mer, que M. Gandolphe a étudié à Dunquerque.

Reaumur has described and illustraed the tentacles or feet very well in the Mém. De l'Acad. des Scienc. Année 1712. He criticized Gandolphe and unjustly and accepted that the sea urchins moved by means of the spines. P. 136. Les Naturalistes néamoins ont eu raison de croire que les oursins se servent de leurs épines, au
} 
urchins are removed from the water and put into a dish without water, they remained immobile with retracted feet. When water was poured out of containers, animals attached to the walls soon retracted their feet and fell.

I was able to admire the fine sense of feeling of the feet. As I maintained more than one sea urchin in a container they had to move with their feet in the previously described fashion. During this the animals touched each other with their feet and moved around each other to continue on their way.

lieu des jambes. Je les ai vu maracher vec ces mêmes épines, dans des circonstances ou il n'etoit par consequent tres facile de les observer' mais ayant mis meme ces animaux sur ma main, je leur ai vu exécuter leur mouvement progressif avec leurs seuls épines. -- Ce fait est donc certain, quelque contraire qu'il-soit aux observations de M. Gandolphe.

P. 137. Les Jambes ressemblent à la verité par leur figure aux jambes des Etoiles, ou, pour en donner une idèe plus claire, à ceux qui ne connoissent par ces jambes, elles ressemblent aux cornes des Limaçons. Aussi ne leur donnerons-nous plus que le nom de Cornes. Leur usage est bien différent de celui que M. Gandolphe leur a attribué, loin de servir à mouvoir les Hérissons, elles servent à les fixer. Le Hérissons, les employer aussi pendant qu'il est en mouvement pour reconnoître le terrain, qu'il environne, comme les Limaçons se servent des leurs, ou comme un aveugle tâe avec im bâton les corps qui se trouvent sur sa route. Pour cela il allonge et raccourcit alternataivement les unes ou les autrest pendant sa marche.

D’Argenville has described and illustrated the tentacles in his Conchyliologie Paris 1757. 4. P. 2. p. 62. Planche 7. fig. A.

Baster has described and illustrated very well the tentacles or feet of Echinus cidaris in the Opusc. subsec. P. 114. He says p. 113: Aculeorum eorundem et proboscidum ope e loco in locum Echini se movement, utrisque eundem in finem utentes: posterioribus tamen potissimum, ut se loco cuidam affigant, quod si fuerint, vi eos avulsurus harum proboscidum aliquot plerumque rumpat.

Janus Plancus (Bianchi) has described the tentacles of sea urchins in his Epistola de incessu marinorum Echinorum ac de rebus quibusdam aliis marinis ad Ferdinandum Bassium in the Comment. Instit. Bononiens. T. 5. P. I. Opusc. p. 236. He has put it beyond all doubt that the sea urchins move with the aid of the tentacles or feet and not with the spines. He says: p. 237. Ut progrediantur vero Echini, in aqua, ita se componunt, nam extra aquam non progrediuntur unquam, ut dixi, ut innumera cornua emittant per foraminula, quae jacent inter spinas. Haec cornua tertio saltem longiora sunt spinis ipsis. Cornibus igitur ipsis veluti cruribus progrediuntur, et tunc immobiles, et radiatim extensos gerunt aculeos. Istis cornibus non tantum progrediuntur, sed haerent quoque, si lubet, loco, cui insunt, ut observavi; nam Echini per ctinum fictile faventino vitro prope obductum, et lateribus ad horizontem parum inclinatis, et fere perpendicularibus aswcendebant et catino itahaerebant interdum, ut non facile aba eo divellerentur. Extra aquam vero Echini statim intra corpus cornua sua recondunt et non amplius icedunt spinas tantum, seu aculeos tunc motitant, quibus se laterliter sint locati, pronos supinosve, eu dixi, se componunt. In catino plano et in discis etiam progrediuintur, et haerent suis cornibus Echini, si aqua tertiam saltem partem eorum corporis operiat, at se aqua omnino detrahatur, immobiles statim subductis cornibus fiunt, et a vase decidunt sponte, si vas inclinetur, quod non ita accidit, si vas sit aqua refertum, cornibus suis fundo, vel lateri vasi arcte insistunt et haerent. Quare apparet, male eos sensisse, qui asserurunt, Echinos spinis incedere; namspinis ascendere nunquam possent, si vas latera habeat laevigata et fere perpendicularia, ut habebat catinum illud vitriatum et lebes aeneus, in quibus Echinos vivos collocavi et ascendere observavi, ut extra ea vasa egrederentur, nisi operiantur. Corpora enim acuta et dura, ut sunt Echinorum aculei corporibus duris et laevigatis nunquam haerere possut, praesertim si latera sint perpendicularia vel ad horizontem parum inclinata.

Spallanzani has likewise described the tentacles and feet and the movement of sea urchins. Letter of Mr. l'Abbé Spallazani à Mr. Charles Bonnet, sur diverse productions marines in Rozier Observations sur la Physique etc. T. 28. Ann. 1786. P. 252. Mouvement progressive des oursins de mer. Spallanzani has shown that the tentacles are the only organs of movement and that the spines have only a small role in movement.

Al. Monro holds incorrectly that Echinus esculentus uses the spines for movement in his Vergleichung des Baues u. der Physiologie der Fische translated from English by J.G. Schneider p. 88. Die Schale des Seeigels ist mit einter Haut bedeckt und hat viele tausend Stacheln, welche durche musculose Bänder damit vergliedert sind. Daher dienen die Stacheln statt der Füsse; und ich sah, dass die Stücke von einer zerbrochenen Schale sich immer nach verschieden Richtungen forbewegten. 
Sea urchins are unable to swim and can move only in the described manner ${ }^{50}$.

The sea water in the containers in which the animals were maintained would turn cloudy due to the occurrence of gray, round excrements. When maintained in the cloudy water the animals will move less and more slowly until the are finally dead on the bottom of the container. I have never been able to maintain a sea urchin in a container when the water was not exchanged for more than two days. A continuous renewal of the water enabled me to maintain animals for a number of days.

The stone sea-urchins are very tough animals. I have dissected these animals more than once and thrown their body pieces into the water. The individual pieces still continued to move for a few hours, even though the movements were slowed down.

\section{Mouth and masticatory apparatus}

Protruding from the round mouth opening are the points of five white teeth turned towards each other. The soft, lip-like skin around the mouth surrounds these teeth. It is connected to the calcareous pieces where the teeth protrude. The membrane in living animals is contractile so that the teeth can be reasonably covered. The teeth and calcareous pieces, which resemble a jaw, can be moved freely in the membrane.

The five teeth are connected to a curious structure made of a number of calcareous pieces that is unique in the animal kingdom ${ }^{51}$. The structure is located within the opening at the lower part of the test and can be moved in different direction by a number of different muscles. The structure of calcareous pieces has been called the masticatory apparatus by a number of natural historian.

The calcareous structure to which the teeth are connected has the shape of a five-sided pyramid, whose tip is made of the tips of the five teeth. The basis of the pyramid that ranges deeply into the coelomic cavity is turned upwards towards the anus. Extending from the middle of this basis is the esophagus. The pyramid is maintained in its position partly by its connection with the membrane and in part by the different muscles (Plate 10, Figure 2.).

The large, five-sided pyramid is constructed of five smaller triangular pyramid-shaped pieces $^{52}$ that have their sharp edges turned towards each other. Located inside the five inner edges of the five smaller pyramids is the esophagus. The outer surface of each of the pyramids has two longitudinal depressions. Located between them is a long triangular opening that is closed by a piece of tissue. Inserted into each of the two indentations is a strong muscle that will be described later. The upper edge of the pyramid, to which two muscles are attached, forms a small bow over the triangular opening. Both side surfaces of the pyramid are indented

\footnotetext{
${ }^{50}$ As Buster also has reported correctly in his opusc. subseciv. p. 116: Echini natare non passunt, sed in funda maris repere aut rupes ascendere illis tantum concessum est.

${ }^{51}$ Aristotle was the first to name this the sea urchin's tooth in his Hist. Animal. Lib. 4. Cap. 5: habet autem echinus dentes quinque cavos. Intus.

Rondelet has described and illustrated the calcareous parts where the teeth are connected in his Piscibus P. I. Lib. 18. P. 578.

Aldrovand has illustrated them in his Schrift de Testaceis Lib. 3. p. 411. Ed. Bonon.

Baster has described the jaws and teeth of Echinus cidaris in his opusculia subsecivis p. 115. And has illistrated it in Tab. II. fig. 6. fig. 8.

Klein has described the jaws and teeth in his Naturalis Dispositio Echinodermatum. ed. N.G. Leske Lips. 1778. 4. p. 33. A good illustration of a single tooth is found in Tab. 31.

Mr. Cuvier has given a good report of the masticatory apparatus in his Anat. Compar. T. 3, p. 329.

${ }^{52}$ Les cinq pyramides triangulaires of Mr. Cuvier.
} 
horizontally and turned towards the next pyramid to which they are connected through short muscular bundles. Each small pyramid is hollow. The hollow cavity contains the long tooth that protrudes from the tip of the pyramid.

The five white teeth are very long, much longer than the pyramids in whose cavities they are located and to which they are connected with their outer surface. They are prismatic, having three edges and slightly curved inwards. The lower end protruding from the pyramids forms a strong tip. The upper end extends from the cavity of the pyramid base and is curved to the inside, surrounding a small, oval, fluid filled bladder. They are very hard and solid at the bottom end. They turn softer in the hollow cavities of the pyramid. The teeth are made of white, asbestos-like shiny fibers that are closely connected.

The five triangular pyramids are connected at their base by five small, long, rectangular, dorsoventrally flattened calcareous pieces ${ }^{53}$. Both long outer sides are connected to the upper side surfaces of the pyramid base. The outer edge is free. Articulated into the inner, esophageal edge is a small semicircular calcareous piece ${ }^{54}$.

The five semicircular, everted pieces are located above the five long, rectangular pieces. Their convex surface is turned up; the concave side, downwards. Each of these pieces widens from the inside to the outside. They all end in two tips, nearly Y-shaped, to which two muscles are connected.

This curious apparatus of small calcareous pieces, which is used for tooth movement to feed, is moved by a large number of muscles that I will now describe:

1) Muscles that separate the five pyramids and the tips of the teeth from each other.

At the edge of the lower opening of the test are five large, arched attachments (Plate 10, Figure 2.a.a.) that resemble the arch of a bridge. Arising from the inner surface of the five arched attachments are ten strong, light-brown muscles, two from each of the arches (Plate 10, Figure 2.b.b.b.). These muscles run to the inside and downwards against the outer surface of the five triangular pyramids. They insert into the grooves that can be seen at the outer surface of the pyramid. Each pyramid contains two of these muscles coming from two neighboring arches. If the muscles contract, the pyramids are separated from the teeth. This increases the space between the tips of the teeth. The muscles also pull the whole calcareous structure farther into the body cavity when they act together.

2) Muscles that pull the five pyramids and muscles towards each other each.

Located between the five arched attachments of the test are five large crescent-shaped ridges. Arising from these are ten long muscles, two from. The muscles run up and inwards and insert into the outer edge of the five pyramid bases above the triangular opening visible in the teeth. Each pyramid contains two of these muscles. When the muscles operate in a living animal, the bases of the pyramids are pulled sideways, and therefore move the tips of the pyramids and the teeth closer together. This movement enables the animal to chew their food. The muscles can therefore be considered chewing muscles. When all muscles act synergistically, which happens most commonly, they move the lantern downwards out of the oral opening. These muscles are also antagonists to the previously described muscles.

3) Muscles that move the semicircular pieces.

Arising from the five ridges between the arched attachments are also ten other white, thin muscles. These attach to the Y-shaped tip of the five semicircular pieces. Arising from each ridge are two muscles. One of these attaches to the tip of the right semicircular piece, the other to the

\footnotetext{
${ }^{53}$ Les cinq pieces ou poutres osseuses of Mr. Cuvier.

${ }^{54}$ Les cinq osselets faits en demi-cercle, as Mr. Cuvier named them.
} 
tip of the other left semicircular piece (Plate 10, Figure 2.d.d.d.). Each of the semicircular pieces thus receives its muscles from two ridges. When operating in life, these ten muscles pull the semicircular pieces downwards and sideways. As these are attached to the long rectangular bone at their proximal end, and the latter in turn to the pyramid base, they increase the upper space between the pyramids by pulling them sideways. They therefore bring the tips of the teeth together. These muscles therefore are considered also as true chewing muscles.

4) Muscles that connect the semicircular pieces.

Located between the semicircular pieces are five small, inner, broad, light-brown muscles - They arise from the edge of one of the semicircular pieces and attach to the edge of the next semicircular piece (Plate 10, Figure 2.e.e.). When these five muscles cooperate, they pull the semicircular pieces closer together. This seems to counteract the contraction of the muscles that move the semicircular pieces sideways and downwards.

5) Muscles that connect the side surfaces of the five triangular pyramids.

The side surfaces turned towards each other are connected through short but strong muscular bundles. These attach to the small and horizontal indentations of the side surfaces of the pyramids. When the muscles contract in life they move the pyramids sideways against each other and constrict the space between them that contains the esophagus.

The calcareous pieces of the structure of the masticatory apparatus to which the teeth are connected is made of a calcium carbonate and phosphate as chemical analyses have proven. The structure was dissolved in sulfuric acid, which caused strong gas formation. The salt of oxalic acid was added to a part of this solution, which lead to the formation of a white precipitate. Lead acetate was added to another part of the solution and also caused a white precipitation. Pure ammonia also causes the formation of a white precipitation.

The nutrition of the stone sea-urchin consists of small uni- or bivalved molluscs that they crush with the teeth and then swallow. I have examined the contents of the intestine a number of times and have always found many small pieces of mollusk shells. Some sand was always mixed with the food, which most likely entered the digestive tract accidentally.

\section{Intestine}

Located within the tips of the five teeth is a soft, thick tissue that surrounds the nearly star-shaped opening of the esophagus. This skin forms a fold between teeth pairs. The esophagus ascends through the so-called lantern into the cavity of the test ${ }^{55}$. If the five small pyramids are dissociated and the esophagus is exposed, ten fine, white threads can be seen that arise from the outer surface of the thick edge of the esophagus. These threads attach pair-wise to the semicircular parts of the lantern. I have been unable to determine if these threads are muscles or tendons due to their fine structure. In the beginning I made the error or considering them nerves.

The esophagus or small intestine coils as it ascends into the cavity (Plate 10, Figure 1.a.b.), turns towards the walls of the test, and ends in another intestine. The connection of the esophagus or small intestine to the other intestine shows similarities with the connection of the small intestine with the appendix in humans. This has already been examined by Alexander Monro $^{56}$. The larger intestine forms a true caecum close to the connection with the esophagus

\footnotetext{
${ }^{55}$ Aristotle named the part of the gullet esophagus between the teeth $\sigma \omega \mu \alpha \sigma \alpha \rho \kappa \omega \lambda \varepsilon \varsigma$ amd compared it to a tongue. Hist. Animal. Lib. 4. Cap. 5. habet autem echinus dentes quinque cavos intus, atque inter eos corpus carniforme pro linqua.

${ }^{56} \mathrm{Al}$. Monro first correctly described the gut of Echinus esculentus in his Vergleichung des Baues un der Physiol. Der Fische translated from English by J.G. Schneider p. 89. Die Sehlundröhre läuft ohnegafähr 3. Zoll in
} 
(Plate 10, Figure 1.c.). It forms two large coils crossing the complete cavity before reaching the rectum.

The first part of the larger intestine, which forms the first main coil, is located at the bottom of the cavity and leads into five small ascending and descending coils (Plate 10, Figure 1.d.d.d.d.). It turns into the second part of the intestine close to the caecum, which now coils in the opposite direction. This region also shows five ascending and descending smaller coils that resemble those in the first main coil (Plate 10, Figure 1.e.e.e.e.e.). This second part of the intestine becomes narrower and runs up- and inward and ends in the anus in the upper opening of the test. This opening is opposite the masticatory apparatus. The final part of the intestine will be called the rectum (Plate 10, Figure 1.f.).

This description of the digestive system shows that the intestinal part of the stone sea-urchin is composed of a small and a large intestine. I shall call the first the esophagus or small intestine and the second, the large intestine. A widening in the form of a stomach cannot be found $^{57}$. Contained within the esophagus and the first part of the intestine is a gray-white, sometimes yellow fluid that tastes bitter ${ }^{58}$.

The second part of the intestine and the rectum always contains small round boluses, which are the feces ${ }^{59}$. These fecal boluses are made of a gray-white mass, which is easily crushed and contains many small pieces. I have sometimes found very small, complete shells of uni- or bivalved molluscs in these boluses.

The walls of the digestive tract are very fine and transparent, so that it is possible to see the materials contained in it. The outer surface of the digestive tract is smooth and made of very fine tissue, and is called the coelomic epithelium. It is attached to the outer surface of the digestive tract to the inner surface of the test by mesenteries that stabilize its position within the coelomic cavity ${ }^{60}$. This tissue also covers the inner surface of the test. Obvious within the whole digestive tract are muscle fibers underlying the upper epithelium. Some of these muscle fibers are longitudinal, some circular. The inner surface of the digestive tract is covered by a soft, yellow-brown tissue, a form of digestive epithelium. This epithelium can often be dissected from

die Länge, is durch ein Ligament an die Seite des Afters geheftet, bierauf macht sie eine Beugung, und öffnet sich plötzlich in einen weiten Kanal, ohngefähr auf die Weise, wie beim Menschen das Ilium sich in die Seite des Colon öffnet. Dieser Kanal oder Darm macht zwei wellenförmige Bogen um die Schale, und senkt sich hierauf in den After.

57Janus Plancus (Bianchi) a. a. 0. p. 241 described and illustrated incorrectly three expansions of the stomach that he compared with the stomach.

${ }^{58}$ Aristotle recognized only the last large coil of the gut with its five loops. Hist. Animal. Lib. 4. Cap. 5. Huic (corpori carniformi pro lingua) continuatur gula; deinde venter in quinque divisus partes excrementi plenus. Conveniiunt autem sinus ejua omnes in unum ad exitum excrementi, qua testa perforata est.

GERMAN $\tau \alpha \mu \varepsilon \lambda \alpha v \alpha$. GERMAN In the following place Aristotle speaks of the dark part: Hist. Animal. Lib. 4. Cap 5. Echini ne carneum quidem hoc habent, sed hoc illis peculiare est, ut carne intus omni privati careant; nigra autem ila habent omnes. Ibid. Ad Toronem Echini sunt tum testis tum spinisatque etiam ovis albis: sed cum longiores ipsi, tum spinae breviores, neque satis firmae, sed molliores. Nigrae autem particulae, quae ori applicatae sunt, plures: eaeque ut ad exitus meatum copulatae, ita inter se disjunctae sunt, namque hic echinus quasi disseptus et dispartitus est. Ibid. Supra haec (ova) nigrae partes illae ab radice dentium ortum habent, prae amaritudine cibo ineptae. Simile corpus aliquod, aut pro proportione ei respondet, in omnibus animalibus adjest; quippe in testudine et rubeta et rana et turbinatis et molluscis reperitur, quamquam colore divorsum. Praeterea haec esui accomodata non sunt; tametsi alia plus, alia minus.

${ }^{59}$ Pet. Belloniius p. 441. Ejus (Echini) excrementa viscida sunt ac lenta, albissima, copiosa: quae ita tandem indurantur, ut cum fidibus de duritia et nervea firmitate certare possint.

Rondelet a. a. 0. p. 579. Excrementa rotunda sunt exiguarum pilularum instar.

${ }^{60} \mathrm{Mr}$. Cuvier says quite correctly in his Anat. Compar. T. 4. p. 149. Dans les oursins, le mésentère s'attache à la coquille extérieure, et se contourne absolument comme l'intestin qu'il embrasse. 
the rest of the digestive tract in the first part of the large intestine in form of a very fine tissue. Arising from the digestive tract are many vascular canals that I shall describe in the part about the vascular system. With a good microscope I have been able to view many white particles in the first part of the esophagus or small intestine that have the shape of small glands.

\section{Organs of respiration}

When opening a live sea-urchin, a large amount of sea water always is found within the test. This water fills the space between the lantern, the digestive tract, the gonads and the test ${ }^{61}$. This water enters the cavity of the test through ten small, branched and tubular organs. These branched organs are located at the lower surface of the sea urchin, close to the membrane that closes the oral opening. These organs only become visible after removal of the spines and feet located on the lower test surface that hide these organs. Other anatomists and zoologists might have overlooked these organs due to their hidden location, as I have never found any reference to these organs in any other publications. The organs are shown on the tenth plate, 5.d.d.d.d.d.

The small, hollow branches are attached to a hollow stem that penetrates the underlying membrane. The ten large, round pores of the branched organs can be seen on the inner surface of the membrane. It only becomes visible after removing the lantern and its muscles (these pores are shown in Plate 10, Figure 3.c.c.). I have often injected mercury through these pores into the tubules, which with a little pressure flowed out of the tips of the vessels. I consider these hollow branched organs analogues of the respiratory tubules of the seastars. Besides these organs there are no other structures that penetrate the test and can lead sea water into the cavity.

The water taken up through the tubules enters the cavity close to the muscles that arise from the inner surface of the arched attachments and attach to the outer surface of the five small pyramids. Here it fills the space between the lantern, the digestive tract, the gonads and the inner surface of the skin. The sea water meets the vascular canals that branch on the digestive tract and the inner epithelium that covers the inner test surface. The blood circulating in these vascular canals is oxygenated through the incoming sea water.

The way the water necessary for respiration is renewed within the test is still a problem. In sea urchins it can not occur as in seastars by contraction of the skin that expels that water, as the calcified and therefore non-contractile test forms the body cavity. I suppose that part of the sea water will be expelled from the body cavity by the movements of the lantern, which will then be replenished by fresh sea water from the external medium.

I have previously described how animals maintained in sea water containing excrements will not survive, and that they can be maintained when the water is changed regularly. The presence of a respiratory process in sea urchins therefore has to be considered.

\section{Vascular System for Circulation of Blood}

\footnotetext{
${ }^{61}$ Janus Planous also has made this observation in the Comment, Bonoieus. T. 5. P. I. Opusc. p. 242: in ventre echinorum loca multa vacua reperiuntur inter intestina et ovaria, quae aqua marina sunt referta, quam fortasse per poboscides, seu per cornua illa sugit, ut dixi, echinus.

Alex. Monro also says a. a. 0. p. 90: Zwischen der Innenseite der Schale und den beschriebenen Theilen, nämlich der Darmrähre und Bogen befindet sich eine grosse Menge Feuchtigkeit, die wwie Seewasser schmeckt und 2/30 ihres Gewichtes bestehen aus einer salzigten Materie, welche vorzüglich aux gemeinen Seesalz mit den gewöhnlich beygemischten fremden Theilen des Seewassers bestand, wie die chemische Untersuchung zeigte. -- Al. Monro believes Anne TRANSLAte GERMAN
} 
If the test of the sea urchin is cut through close to the anus and the top of the test removed, it is possible to see the digestive tract and the associated vascular canals. Not only have I opened the test in this way, but also close to the mouth as well as vertically to see the position and distribution of the vascular system. It is not possible to view the vascular system in every sea urchin but only in those in which the canals are fluid filled. I have been able to fill the large vascular canals with mercury but never the small canals. This was partly due to their small diameter as well as their thin walls as the mercury would rupture them with injection. After sea urchins had been stored in spirits for a while, I was no longer able to fill the canal system with mercury as the fluid contained in the canals would coagulate and block mercury flow. Figure 1 in the tenth plate shows a successfully opened sea-urchin divided into two parts, including the proper location of the digestive tract and the associated vascular system.

There are two main vascular stems visible along the intestine, one located on the inner, one on the outer edge ${ }^{62}$. It is also possible to view a circular canal that surrounds the inner test surface where the rectum penetrates the upper test to open to the outside. This circular canal $(g$.) is located close to the five gonopores of the ovaries. Arising from this is a short canal $(h$. $)$ which descends along the lantern and empties into a brown, oval canal (i.) about two mm in length. Arising from this canal, which is located close to the esophagus or small intestine close to the lantern, is another canal. This canal sends branches into the esophagus. These enter the lantern and branch in part on the esophagus and in part on the muscles and tendons of the lantern. One branch of this vascular system descends along the esophagus or to the small intestine where it leads into the large intestine. This branch continues as a canal that runs aside the inner edge of the intestine (l.l.l.l.). This canal is constructed of interconected, encircling brown muscle fibers. I was able to see this under the microscope. As this canal expands and contracts in a living animal, I have named it the heart canal. Opening the test tears the canals that lead from the circular into the heart canal so that it hangs off the esophagus. It can also tear the canals leading from the heart canal to the intestine, so that they hang off the rectum and the circular canal ${ }^{63}$. I have sometimes managed to open the test at its lower surface and excise the lantern so that the heart canal remained intact.

This canal that arises from the heart canal increases in size as it goes to the small intestine towards the large intestine (?). It runs along the inner edge of the first main coil of the large intestine (l.l.l.l.) and continues, smaller in size, around the second main coil of the large intestine towards the rectum. During this whole development there are a number of small small canals arising towards the upper and lower surface of the intestine that also banch on it. I have been able

\footnotetext{
${ }^{62} \mathrm{Al}$. Monro a. a. O. S. 89 was the first to find and describe this vascular system in Echinus esculentus. Here is his description of it: "Am unteren Rande von der ganzen Länge des Gekröses fand ich zwei Gefässe ohne Klappen, ohngefähr von derselben Grösse und parallel liegend, welche ich mit Quecksilber anfüllte; und dadurch füllte ich ein schönes Netz von Gefässen nicht allein an den Därmen, sondern auch andere, die über den feinen Häuten, welche die Därme an die innere Seite der Schale befestigen, zerstreut liegen. Jedoch konnte ich nicht bemerken, dass diese zwei Gefässe irgend eine Gemeinschaft mit einander hatten, entweder unmittelbar oder durch ein Organ wie das Herz, auch konnte ich an dem lebenden Thiere kein schlagendes Organ, wie das Herz bemerken. Doch nahe am After, und mit dem Mastdarm verbunden, wo bein manchen andern Würmern das Herz liegt, fand ich ein kleines Organ, welches hohl zu seyn scheint. Es scheint mir höchst wahrscheinlich, dass eins von diesen Gefäfsen die grosse Pulsader oder Aorta sey, und dass das andere mit unserer Hohlader übereinkomme; dass sie durch unsichtbare Aeste mit einander verbunden sind, und das Blut vermittelst dermuskulösen Wirkung ihrer Häute ohne die Dazwischenkunst eines Herzens umtreiben, ohngefähr so wie bei den Fischen die Blutgefässe das Blut aus den Kiemen nach dem Herzen zurückführen.

63 Alex Monro has mentioned this canal but did not know its function, a. a. 0. p. 89. Nahe am After und mit dem Mastdarm verbunden, wo bein manchen anderen Würmern das Herz liegt, fand ich ein kleins Organ, W. Platte 43. Fig. 2, welches hohl zu seyn scheint.
} 
to fill this vascular stem with mercury a number of times. The mercury also entered the small branches that are located along the intestine. The canal was drawn after these injections. In life this canal contains a dark-yellow, nearly orange fluid that quickly clots in alcohol. I have also noted in living sea urchins that this canal contracts somewhat when irritated by a needle. I therefore considered this canal as the intestinal artery.

Located on the outer edge of the intestinal tract is another large canal (m.m.m.m.m.) that contains a yellow-white fluid. It is largest in the middle part of the intestine and decreases in size towards both ends of the intestine. The anterior part runs along the esophagus into the lantern. I have followed the posterior part into the area of the rectum. This canal followed all the coils of the intestinal tract and picks up a number of small canals on its inner side which arise from the walls of the intestine. On its outer side it sends of a large number of fine canals to the membrane that lines the test on the inside. These canals run there where the mesenteries hold the intestine in position. Mercury injected into this vascular stem also enters the small canals on the intestinal walls and those on the inner membrane of the test. I have been unable to see clearly contractions and expansions of this canal, even when I irritated it with a needle.

I consider the vascular stem on the outer edge of the intestine to be the intestinal vein that takes up blood from the intestinal walls and absorbs nutrient fluids. I have been unable to see absorbing veins on the intestine. The following reasons are the basis for this opinion:

1. The fluid contained in the the outer vascular stem is yellow-white, while the fluid on the

vascular stem around the intestinal tract is dark yellow.

2. I have found no distinct contractions or expansions in the vascular stem on the outer edge of the intestinal tract. I have, however, found these contractions in the vascular stem on the inner edge on the intestinal tract.

The vessel stem of the outer intestinal edge, or the intestinal vein, is widest in the middle and decreases in size towards both ends of the intestine. It does not lead back into the heart canal or the inner intestinal vascular stem, which means that it has to send out canals as an artery and take up canals as a vein. I consider the canals coming from the digestive tract to be veins, those on the inner membrane of the test, arteries. In fact I suppose that in these last canals the blood mixed with chylus is oxygenated by the sea water taken up into the coelomic cavity. The blood is turned into arterial blood as the sea water taken up bathes the membrane that lines the test internally. Therefore the vascular stem located on the outer edge of the intestinal tract can also be considered as intestinal vein and respiratory artery simultaneously.

At its outer edge, the circular canal surrounds the rectum at the test (n.n.n.) and takes up a number of vascular canals that come from the membrane that lines the test internally. These canals probably distribute the oxygenated blood into the circular canal, from whence it is transported into the heart-like canal. This circular canal can therefore be considered as the respiratory vein. The heart-like canal distributes the blood through its contractions into the vascular canal arising from it. This canal distributes the blood through its branches to the inner edge of the intestinal tract, the lantern and the walls of the intestinal tract. It functions as an artery. From the intestinal walls the blood reaches the vascular stem located on the outer edge of the intestinal tract. From here it probably reaches the circular canal through the canals of the internal epidermis covering the test, from whence it finally returns into the heart-like canal.

This is a description of the vascular system of the stone sea-urchin as far as I have been able to examine it. The small size of this type of urchin has made it impossible to perform other experiments to support my findings. 


\section{The Vascular System of the tentacles or feet ${ }^{64}$}

Visible on the inner side of the open test, after removal of the intestinal tract, are five light-brown canals or vascular stems (Plate 10, Figure d.d.d.d.). These appear from under the arched attachments on the inner rim of the lower opening of the test (Plate 10, Figure 2.a.a.). These five canals ${ }^{65}$ decrease in size on the inner side of the test towards the upper opening, close to the circular canal from which the heart-like canal arises. The five canals, however, have no connection with the heart-like canal. Arising on both sides of the five canals are a large number of small, dense side branches. These side branches, arising from the canals at a right angle, decrease in size and length towards the top of the test. When the side branches are removed from one of the canals it is possible to see four slightly curved rows of small holes (Plate 10, figure 1.e.e.). These penetrate the test and continue into the hollow feet ${ }^{66}$.

The five canals continue below the arched attachments on the outer surface of the membrane (Plate 10, figure 3.d.d.d.d.d.). Here they lie among the five muscle pairs that arise from the inner surface of the arched attachments and attach to the outer surface of the five smaller pyramids. The location of the five canals can be seen only after removing the lantern and its muscles. They appear between the tips of the small pyramids and continue into their cavity that contain the teeth. They emerge on the upper surface of the pyramids and form five oval vesicles (Plate 10, figure 2.f.f.f.f.f.). These are located between the five semicircular pieces of the lantern and a little underneath the muscles that connect these pieces ${ }^{67}$.

These previously described five vesicles and canals with their side branches are filled with a light, transparent, non-salty liquid that probably is excreted from the vascular system of the intestinal tract that enters into the masticatory apparatus. The walls of the canals and side branches that run on the inner surface of the test are surrounded by circular muscles fibers that can be seen easilyn under the microscope ${ }^{68}$. In life these canals are irritable as they will contract when irritated by a needle or ethanol. When irritated they contract and distribute the fluid they contain through the holes in the test into the hollow feet that therefore erect. When, however, the feet are irritated into contraction, the fluid will leave their cavity and disperses in the side branches and their canals, which therefore are expanded. The vesicles located on the upper surface of the lantern are made of a thin, transparent, white epidermis in which I was unable to detect any muscle fibers. I suppose that the fluid contained within these vesicles is moved into the canals by contraction of the muscles that connect the semicircular pieces. This was concluded because these muscles run circularly across the inner part of the vesicles.

\footnotetext{
${ }^{64} \mathrm{Al}$. Monro a. a. 0. p. 90 has regarded this vascular system incorrectly as an apparatus of absorption

65 Al. Monro has shown these canals and their side branches in his Seitenästem Taf. 43. Fig. 1. 2. R.S.T.U.V. und Taf. 44. fig. 13. D.E.F.H. I was unable to find a coiled interconnection of the vascular canals described by Monro in his Taf. 44. fig. 14.15.

66 This system also has been found and illustrated by Al. Monro.

67 Al. Monro described and illustrated the vesicles a.s.O.page 91. Der zuletzt beschriebene Stamm, dergleichen fümf sind (Taf. 43. Fig. 1 und 2. R.s.T.U.V.) Theilt sich in zwei Aeste, welche sich in grosse Säcke oder Behälter, die (Taf. 44. G.G.G.G.) über den Zellen der Zähne liegen und miteinander Gemeinsehaft haben, endigen. Aus diesen geht die Feuchtigkeit an den Zellen der Aähne herunter und ergiesst sich in die See an jeder Seite des Zahns zwischen der Zahnzelle und dem Anfange der Speiseröhre (Taf. 44. fig. 17.E.E.) -- The latter statement is completely incorrect.

${ }^{68} \mathrm{As} \mathrm{Al}$. Monro describes it also a. a. 0. p. 91: Die inner gefaltete Haut is ebenfalls sammt ihrem Geflechte von Gefässen, ganz offenbar musculös, weil sie ihre Gestalt und Lage verändert, sobald sie mit einem Messer oder Sonde etwas unsanft berührt, oder wenn Seesalz darauf gesprengt wird.
} 
I have assured myself of the inner connection of the vesicles with the five canals. They first of all descend in the cavities of the small pyramids and then run along the inner surface of the test. I have also investigated the connection of the side branches and holes in the test with cavities of the feet by the following experiments. I have inserted the tubule of the mercury-filled glass cylinder into one of the vesicles. The mercury entered the canal located within the pyramid, continued underneath the arched attachments in the canal, entered the side branches and finally filled even the hollow feet. When I let the mercury exit the vesicle by inverting the test with the lantern, the mercury left the side branches and canal. The injection of the parts named worked completely only in a very large stone sea-urchin. The injection only worked partially in sea urchins that had been preserved in ethanol for an extended time as the ethanol had decreased the diameter of the canals and branches. I have also managed to blow air into the canals and bladder through a little glass rod, which filled the system ${ }^{69}$.

This concludes that the previously described bladders and canals with their side branches are analogous to the vascular system of the feet, which I have also discovered in holothuroids and sea star. The functions of these systems are also the same, as they serve to provide the fluid necessary to erect the hollow feet and to take these fluids back up when the feet are retracted ${ }^{70}$. The bladders, canals and their side branches are antagonistic to the hollow feet. When they are contracted the feet are expanded and fluid-filled. Vice versa, when the feet contract the fluid enters the test through the holes and fills the side branches and canals, which expand. Therefore there is no real circulation but simply a streaming from part of the system to another. This is caused by the changing contractions and expansions of canals, side branches and feet. It seems

69 Al Monro also had injected this vascular system with mercury. He reported a.a.O. page 90: Wenn man die swei Eoffnungen auf der Schale verfolgt, so findet man, dass sie an die beiden engegengespetzten Seiten der Reihe von Löchern auseinandeer gehen Taf. 44. fig. 1. 2. 5. und zu gewissen Blättern oder häutigen Falten führen, die den Unterabtheilungen an den Kiemn der Roche night unähnlich sind, Taf. 44. fig. 13. D.E. Wenn ich Quecksilber in die Mündungen der äufseren einsaugenden Gefässe brachte, so konnte ich damit vollkommen die inneren bäutigen Blätter oder Falten fullen und ausdehnen Taf. 44. fig. 13. D.E. Nahm ich alsdann ein Vergrösserungsglas zu Hüfe, so konnte ich die Günge, wodurch das Quecksilber in die Falten gekommen war, deutlich erkennen, ja ich konnte sogar ein Geflechte von Communications-Kanälen auf denselben underscheiden, mit einem zirkelformigen Gefässe umgeben, aus welchem das Quecksilber durch eine einfache Röhre in einen gressen Kanal gieng, dessen Durchmesser ohngefähr den 21sten Theil eines Zolles betrug, under dere statt eines Stammes dient, die Flüssigkeit von einem Paar der Reihenlöcher aufzunehmen. Taf. 44. fig. 13. D.E.F. fig. 14. 15.

P. 91. Die Gefässe haben keine Klappen; denn man kann durch die inneren Stämme das Geflechte zuf gefalteten Häuten und die äusserem Gefässe ausspritzen; oder auch, wenn man nach dem Tode die Zähne mit ihren Zellen einwärts drückt, so geht die in den inneren Kanalen euthaltene Feuchtigkeit durch die Schale und erfüllt die äusseren Gefässe. Aber eine Gemeinschaft der inneren Gänge und Geflechte mit der Höhle innerhalb der Schale, lässt sich durch Quecksilberinjektionen nicht

$70 \mathrm{Al}$. Monro considered the feet and their vascular system inaccurately as suction vessels, a. a. 0 . page 92 where he expressed this opinion: Die Betrachtung des Baues dieser Gänge lässt gar nich zweifeln, dass di äusseren Mündungen der Gefässe das Seewasser einsaugen und durch ihre Röhre in das Geflechte der inneren häutigen Falten bringen; aus diesen sondert sich ein Theil davon durch unsichtbare Gefässe in die Höhlung der Schale ab, das übrige Seewasser aber geht aus dem Geflechte in die funf grossen inner Gänge, und aus denselben durch die Behälter an den Wurzeln dere Zahnzellen, um sich in die See durch zehn Oeffnungen neben den Zähnen zu ergiessen.

Man muss annehmen, dass das Waser in der Schale Beständig abwechselt, und dass also ebenso einsaugende, wie absondernde Gefässe die miteinander zusammentreffen, da sein müssen. Diese aber sind unsichtbar, und es bleibt unbestimmt, ob sie sich in das Geflechte und die funf innern Gänge oder mit den Milchgefässen in die Blutgefässe des Thieres endigen.

Kein anderes Thier bietet wie es scheint, eine so schöne Gelegenheit dar, den Bau der einsaugenden Gefässe und ihre Art zu wirken, zu untersuchen u. s. w.

Diese Meinung beruht ganz auf irrigen Thatsachen. 
very likely that the fluid contained within the feet also nourishes the walls of the feet through diffusion. At least I have not found any canals that connect the blood circulation to the feet. I was unable to determine whether this vascular system also nourishes the calcareous test.

\section{Structure of the feet and tentacles}

The feet of the stone sea-urchin are located between the spines in ten rows that run upwards from the mouth towards the anal opening. Each foot is hollow and has a cylindrical form (Plate 10, figure 3.h.h.h.h.) It ends in a round suction cup in whose middle a small indentation is visible (i.i.i.i.) That does not lead into the foot cavity ${ }^{71}$. The hollow feet are in contact with the side branches of the five canals running along the inner surface of the test. Two small holes in the test (Plate 10, figure 3.g.g.g.g.) lead to each foot whose base is located on the outer surface of the test. Filling the cavity of a foot leads to its expansion and erection. The fluid re-enters the side branches and canals through the same hole when the feet retract.

From the outside the feet are made of a layer of closely linked red-brown, circular muscle fibers. Above these run several threads of longitudinal muscles fibers every now and then. Their inner surface is smooth and is bathed by the clear, transparent fluid. In life the contractions of the circular muscle fibers leads to the movement of the fluid through the holes into the side branches when the animal needs to retract its feet. The longitudinal muscles allow a movement of the feet in all different directions. The feet show an antagonism with the canals and their side branches located on the inner surface of the test. When they are contracted the feet are expanded and vice versa.

\section{Ovaries $^{72}$}

Located on the inner surface of the upper half of the test between the five large canals and their side branches are five long, very large gonads (Plate 10, figure 4.b.b.b.b.). Their outer surface is connected to the epidermis that covers the internal part of the test. Located on their inner surface is the last section of the coiled large intestine. The gonads are constructed of a large number of small, round, orange bodies that I consider to be the eggs. A small tubule arises from the upper part of the ovary next to the rectum (Plate 10, fig. 4.c.c.c.c.). This tubule opens through a hole in the test next to the opening of the rectum ${ }^{73}$. I have never found different organs that resemble the male reproductive organs.

\section{Structure of the test ${ }^{74}$}

\footnotetext{
71 As Al. Monro a. a. O. has wrongly stated and even illustrated. Taf 44. fig. 6.7.8..

72 Aristotle has described the ovaries of the sea urchin. Hist. Animal. Lib. 4. C. 5. Habent ova omnes (Echini), sed quidem minima et cibo inepts. Sub ventre in altera membrana ova quaae appellantur, conotinentur, seque singulis quina, quippe imparia. -The eggs were eaten by the Greeks. Ib. Echinorum genera plura sunt: unum esculentum, in quo quae ova appellantur grandia atque usui utilia sunt, aeque in majoribus atque in minoribus. Nam etiam ab initio statim parvi ea habeut.

The ovaries are also described by Rondelet a. a. O. In addition by Baster in the Opusc. subseciv. p. 115. In Echinus cidaris; also by Mr. Cuvier in his Anat. Compar. T. 5. p. 199.

${ }^{73}$ Janus Plancus in the Comment. Bononiens. T. 5. P. I. Opusc. p. 242 says correctly: Quinque aliis denique foraminibus circa anum instructa est quaelibet echinometra, ut per eorum singula copiosa ova excludantur quae in ovariis copiosa sember reperiuntur.

${ }^{74}$ Reaumur has first given a good description of the test and spines of sea urchins in the Mém. De l'Acad. des Sc.
} 
The test of the stone sea-urchin when deprived of spines and feet is round and somewhat dorsoventrally flattened. Two main openings can be distinguished, a larger lower and a smaller upper opening. The lower, large opening, located in the middle, is closed by a membrane whose center forms the oral opening as I have already previously described. Located in the upper, smaller, and also central opening of the test is the end of the rectum that is surrounded by calcareous pieces.

The test itself is constructed of twenty rows of small calcareous plates that are interconnected at their sutures. The edges of the individual plates are wavy and insert into each other, forming the sutures. These sutures have a high degree of similarity with the sutures of human skull bones. The rows of plates run from the upper to the lower opening. Two rows of plates always form a long, narrow triangle whose tip is pointed upwards. This triangle continues to increase in width from the upper to the lower surface, but then decreases in size towards the oral opening. Five small and five large triangles can be found, which are connected by sutures and form the test. Adjacent to a larger triangle is a smaller one, adjacent to which there is again a larger and so forth. The plates of the five smaller triangles are differentiated by the presence of small holes. Through these holes the side branches of the vascular system continue into the feet, as described earlier.

The number of plates per row that make up a triangle depends on the age and size of the sea urchin. I found few plates in small urchins and many in large ones. This means that sea urchins do not only grow by enlargement of the individual plates, but also by formation of small, new plates. The fact that the test is constructed of many small suture pieces may well favor growth that would be impossible if the test was constructed of one piece.

I want to describe here the test of a very large sea urchin that measured $9.75 \mathrm{~cm}$ in diameter. Each of the rows of a small, or thin triangle was made of 24 plates (Plate 10, fig. 6. shows an enlarged picture of the plates of such a triangle). The plates increase in size towards the middle of the animal but decrease again in size towards the oral opening. Each plate (a.a.a.a.) with exception of the last two (b.b.) have the form of a pentagon. The upper and lower edge of the plate is connected to the edges of the next plate from the same row. The two smaller edges of one side connect to the edges of two plates of the next row of the triangle. The fifth also smaller edge is connected to the edge of the following row of the large triangle. Approximately in the middle of each pentagonal plate is a small, round protrusion to which a large spine is connected. Located next to this protuberance is usually another protrusion for the attachment of a smaller spine. I have also found two or three other protrusions on the largest plates.. Each plate contains ten small holes, located in two slightly crooked rows (c.c.c.c.). Two adjacent holes from both rows always lead to one of the hollow feet on the outer side. On the inner test side they connect to a side branch of the vascular system. There are therefore five feet associated with each plate. The last two plates of a small triangle (b.b.), located on the edge of the lower opening, are long and turned towards each other at their ends. This makes them able to touch, which results in the construction of an arched attachment (Plate 10, fig. 3.b.b.).

This description reveals that a small or slender triangle of the sea urchin examined contained 48 plates. Each of these 48 plates contains one protrusion for the spine attachment, which means that there are 18 large spines on a small triangle. Located on each of the 48 plates

\footnotetext{
Ann. 1712, p. 137.

Baster has described the test of Echinus cydaris in the Opusc. subseciv. p. 117.

Janus Plancus (Bianchi) also has described well the test of a sea urchin in the Comment. Instit. Bononiens. T. 5. P. I. Opusc. p. 259.
} 
are also two small protrusions for small spines, which leads to an amount of 96 small spines per small triangle. The 48 plates of each small triangle also contain ten holes each, meaning that there are 480 holes on each small triangle. As it is always two holes that lead to a foot, there are 240 feet per small triangle. All five small triangles are made of 240 plates total, carry 240 large spines and 480 small ones, so a total of 720 spines. All five small triangles have 2400 and 1200 feet.

Each of the five large, broader triangles is made of two rows of large but less numerous plates. I counted 19 plates per row (Plate 10, fig. 7). These plates (a.a.a.a.) increase in size towards the middle of the triangle and then decrease from the middle towards the oral opening. These plates also have the shape of a pentagon whose edges are connected to adjacent plates in the same way as in the small triangles. Located in the middle of the outer surface of each plate is again a small protrusion which a large spine is connected. The second to sixth plate contains two smaller protrusions besides the large. The seventh to fourteenth plate contain three to five small protrusions aside from the one large. The fifteenth to seventeenth plate again contain two additional small protrusions. Besides the larger and smaller protuberances I also found four to seven extremely small protuberances, which are distributed between the larger ones and carry the smallest spines. The plates of the large triangle do not contain holes so that there are no feet located on them.

These descriptions indicated that one large triangle of the sea urchin examined is constructed of 38 five-angled plates. Each of these carries one protuberance for the attachment of a large spine, so that there are 38 large spines per large triangle. The second to sixth plate also contain two smaller protuberances and therefore spines. This means that these plates contain an additional 20 smaller spines. Plates seven to fourteen contain an additional four small protuberances and spines on average, which means that these plates carry an additional 64 smaller spines on average. Plates fifteen to seventeen carry two additional small protuberances and therefore contain 12 smaller spines. On all plates combined there are also 96 small protuberances to attach to very small spines. On average there are also five very small protuberances per plate, which means that there are 190 very small spines on all plates of the large triangle combined. This means that there are all large triangles together are constructed of 190 plates, carry 190 large, 480 small and 950 very small spines. The sum of all spines on the large triangle is 1620 .

Located between the tips of the ten triangles of the small and large triangles are five large and five small plates, which form a ring ${ }^{75}$ (Plate 10, fig. 8.). These surround the end of the rectum. The five larger plates (a.a.a.a.) have a nearly heart-shaped form. Located on them are three larger and two smaller protuberances that carry spines. Each of these plates also contains one hole (b.b.b.b.b.) which release the gametes. One of these five plates is slightly larger than the others $(c$.). Arising below it is the circular vein stem that surrounds the rectum. Attaching to the hind edge of the five larger plates are the tips of the five triangles. These five large pieces (d.d.d.d.d.) are nearly triangular and located in the angles formed by two larger plates. They also contain two to three protuberances with spines attached. Attaching to the hind edges of these are the tips of five smaller triangles. The end of the rectum is also surrounded by additional very small plates that also contain some protuberances. When these plates are aligned they close the anus.

\footnotetext{
${ }^{75}$ Baster in the Opusc. subseciv. p. 114. Perasis vero aculeis, superius testae culmen cira aperturam, qua excrementa animal exonerat, in decem, quinque etiam majora et quinque minora, quasi pentagona divisum apparet; quorum unum e majoribus, structurae a reliquis divisae, ejusdemque videtur naturae, quae in stellis marinis sive Asteriis deprehenditur.
} 
Attached to the semicircular, rounded protuberances of the outer surface of the test are the spines. Each spine (Plate 10, fig. 3.o.) has a club-shaped form. Located on its base is a nearly semicircular cavity that fits into the protuberance on the surface of the test. The connection of the spine with the protuberance on the test is made by a whitish tissue. This tissue connects from the edge of the spine base to the edge of the protuberance. It also surrounds the complete outer surface of the test with exception of the round protuberance, which means that all spines are connected to the test through this tissue. This tissue is irritable in life. When the tissue contracts the spines will be erected, when it expands the spines are in reasonably close contact with the test. As there is no real muscle connected to the spine movement, the white irritable tissue covering the test and connecting the spines to their protuberances can be compared to the skin muscle of the mammals. This muscle, when contracted erects the hairs or spines of these animals ${ }^{76}$.

The test as well as the spines of the sea urchin is made of calcareous carbonate and phosphate, as the following experiments prove that were conducted with the test including the spines. A piece of the test was dissolved in sulfuric acid, which lead to a strong bubbling. When a part of the test was dissolved only small pieces of tissue remained, which possibly contained insoluble calcareous parts. Addition of lead acetate to part of the solution led to a slight cloudiness of the solution. Pouring carbonated water on another part of the solution caused a precipitation. Adding the acid of sour clover to the solution caused a large amount of precipitation. The same observations were made for spines of the stone sea-urchin dissolved in sulfuric acid.

The complete test of the previously described sea urchin was constructed of 440 plates, 240 from small tirangles and 190 from large triangles, and ten plates surrounding the anus. All these plates together contained 2385 spines, 720 on the small triangles, 1620 on the large triangles, 40 on the ring that surrounds the anus, and finally five on the tiny pieces around the anus. Associated with the ambulacra are 1200 feet. The test of the stone sea-urchin is made of a large number of individual pieces just like the body of the orange seastar.

\section{Speculations on the Nervous System}

In large stone sea-urchins that were stored in ethanol for an extended period of time, I have often found a mesh of fine, white threads on the inner surface of the membrane. I have also seen these threads ascending the outer surface of the lantern where the small muscles connect the two smaller pyramids. Finally I have also observed white threads on the five canals. These ran along the length of these canals and possibly send branches to the side branches of the vascular system that are connected to the feet. I have not been able to establish the connection of these threads, however, not out of lack of trying. It seems very possible that there is a nervous ring surrounding the mouth on the inner surface of membrane. Arising from this ring could be branches for the muscles that move the lantern pieces and branches for the five canals. These

\footnotetext{
${ }^{76}$ Janus Plancus (Bianci) says very correctly a. a. O. p. 240: Spina quaeque excavata est eo in loco, quo jungitur, seu articulatur cum papilla illa, quae e corpore Echinometrae exstat. Papilla ipsa impervia est, neque cum internis partibus animantis communicat; quare apparet moveri spiinas ope membranae tenuissimae, quae cutis instar Echinum universum extrinsecus ambit. Echini igitur cutim hanc moventes spinas etiam movent, uti canes faciunt, quibus a natura datum est, ut per panniculum carnosum cutem ipsam et pilos simul movere possint, quod nobis hominibus concessum non est. Quare ex hoc etiam patet, minus apte eos sensisse, qui opinati sunt, echinos spinis veluti pedibus procedere. Cutis enim non ita potest se disponi, ut ad nutum animantis tot motus conficiat, quot sunt necessarii, ut ipse incedat, et in tot, tamque varias partes moveatur.
} 
could send out side branches to the vascular side branches and feet. Whether these speculations about the nervous system are correct can be determined by anatomists who have the fortune to examine large species of sea urchins. 


\section{LEGENDS TO THE ILLUSTRATIONS}

$\mathrm{OF}$

\section{THE TUBE HOLOTHURIAN}

\section{First Plate}

Figure 1 illustrates a large living tube holothurian at the height of its expansion during movement.

$A$. The anterior end of the body with the mouth and the tentacles.

$B$. The posterior end of the body.

$C$. The upper surface or the back of the animal with tubercles and tentacles.

$D$. The lower surface or the stomach with its cylindrical feet.

a.a.a.a..The branched and fringed tentacles with its depressions.

$b$.. The mouth

c. A large fold of the body wall.

d.d.d.d. The cylindrical feet with their suckers while extended.

e.e.e.e.e. The tubercles on the back, partly with extended, partly with retracted tubules.

$f$. The opening of the egg canal.

Figure 2 illustrates the posterior end of the body with the narrow opening to the cloaca.

a. The narrow opening of the cloaca.

Figure 3. The posterior end of the body with expanded opening to the cloaca.

a. The extended opening of the cloaca.

\section{Second Plate}

Figure 4. The anterior end of the body shown from inside.

a.a. The two oval vesicles.

$b$. The ring canal, which forms the two vesicles around the dissected stomach.

c.c. The two branches ending in the ring canal that surrounds the mouth inside the calcareous ring.

d.d. The canal that surrounds the mouth, opened on one side.

e.e.e.e.e. The blind endings or ampullae of the tentacles.

f.f.f.f.. The five longitudinal canals.

g.g.g.g.g. The ten longitudinal muscles.

$h . h$. The calcareous ring.

i.i.i.i. The circular muscles of the body wall.

Figure 5. The dissected calcareous ring.

a.a. The larger pieces.

b.b. The smaller pieces. 
Figure 6. A specimen of the tube holothurian opened ventrally in which the complete intestinal tract and the respiratory organ are visible.

$A$. The mouth with retracted tentacles.

$B$. The posterior end of the body with the opening into the cloaca.

a.a.a.a.a. The intestinal tract.

$b$. The cloaca.

c.c.c. The muscular bundles arising from the circular muscles of the body wall. These terminate around the cloaca.

$d$. The short stem of the respiratory organ.

e.e.e.e. Both branches of the respiratory organ.

$f . f . f$. Both vascular canals that are connected to the right branch of the respiratory organ.

$g$. The oval, fluid-filled vesicle.

$h$. The ring canal surrounding the mouth.

i.i. The branches arising from the ring canal and running towards the anterior.

$k$. The small brown, gland-like bodies.

$l$. A dissected tentacle with its appendage, in which the opening can be seen. The fluid

will flow through this opening from the canal which surrounds the mouth into the hollow tentacle.

$m$. The tentacle with its blind appendage.

$n$. The ovary.

$o$. The egg tube or excretory duct of the ovaries.

p..The white, pear-shaped bodies, possibly male gonads.

\section{Third plate}

Figure 7. A tube holothurian opened at its ventral side, in which the intestinal tract with the vascular system can be seen. The first and second sections are pulled apart to show the vascular system more clearly.

$A$. The anterior end of the body with retracted tentacles.

$B$. The posterior end of the body.

a.a.a.a.a. The intestinal artery, which becomes smaller towards the end of the intestinal tract.

b.b. A small anastomosis.

c.d. Both ends of the larger, dissected anastomosis.

$d$. The tubule of the glass cylinder was inserted into this end and the vascular system was filled with mercury.

$e$. This end was constricted before injection of mercury.

$f$. The small arterial ring around the stomach, located next to the ring canal.

g.g.g.g. The large vascular net, arising from the intestinal veins.

$h . h$. The stems of the intestinal veins.

i.i.i. The stem analogous to the lung artery, arising from the intestinal vein stems.

$k . k . k . k . k$. The vascular branches, arising from the stem of the lung artery. They branch further on the right branch of the respiratory organ.

l.l.l.l.l. The branches analogous to the lung veins, in which the branches of the lung arteries terminate.

m.m.m. The stem of the lung veins. 
$n$. I have constricted the intestinal artery a number of times during injection at this location in order to help find out whether the mercury reaches the intestinal artery through the intestinal veins, the canals around the respiratory organ or through the branches of the lung vein.

$o$. At this point the venous blood coming from the third section of the intestinal canal joins with those in the respiratory or lung vein.

p. The cloaca.

q. The stem of the dissected branch of the respiratory organ.

\section{Fourth Plate}

A tube holothurian opened along the ventral side. The intestinal tract, its vascular canals and respiratory organ, as well as the oval vesicle and the ovary are removed.

$A$. The anteriort end of the body with retracted tentacles.

$B$. The posterior part of the body.

C.C. Part of the muscles and vessels, separated and pulled back from the body wall.

a.a.a. A part of the entrails to which the first section of the intestinal canal connects.

b.b.b.b.b. The five longitudinal canals of the ring canal located within the structure of the calcareous ring surrounding the mouth.

c.c.c.c.c. The side branches of the longitudinal canals that open into the feet.

d.d.d.d.d. The vesicles of the appendage of the feet.

e.e.e.e.e. The opening to the feet after dissection of the vesicles.

f.f.f.f.f. The five pairs of longitudinal muscles.

g.g.g.g.g. The circular muscles.

$h . h . h$. Three opened hollow feet.

i.i. A part of the epidermis with sectioned feet that was separated from the body wall.

$k . k$. Dissected muscle portions that connect the horizontal muscles to the cloaca.

LEGENDS TO THE ILLUSTRATIONS

OF THE

ORANGE SEASTAR

Fifth Plate

This plate represents the complete upper surface of the orange seastar. The middle part is slightly raised as the stomach lying below was full.

The rays $A$. $A$. $B$. and $C$. are completely extended with their star-shaped processes. The star-shaped processes are removed in $D . E$.

a.a.a.a.a. The calcareous pieces located around the edge of the rays, including their small thorns or spines.

$b$. A star-shaped process with its small spines extended.

c. A star-shaped process with its small spines retracted.

d.d.d.d. The long spines or thorns connected to the lower calcareous pieces.

$f$. The calcareous buttons that connect the small rays of the star-shaped processes. 
$m$. The flattened, round, stony body from which the stone or sand canal arises internally. x.x.x.x.x. The soft, hollow tubules, through which seawater enters the body cavity.

\section{Sixth Plate}

This plate represents the oral surface of the orange seastar.

$a$. The mouth opening.

$b$. A tooth-like process in front of the mouth.

c.c.c.c.c. The feet.

Feet that show suckers at their end. The otherwise pointed feet take this shape when the animal wants to attach.

d.d. Part of the ring vessel around the mouth, arising from which are brown-yellow vessels

that run between the rows of feet. Only two vessels are drawn here. Along the vessels. The feet have been removed and it is possible to look into the cavity. e.e.e.e.e. Rough, calcareous pieces to which the spines or thorns are connected. f.f.f.f.f. The longest and most exterior spines on the calcareous pieces. g.g.g.g.g. Flattened and rounded processes that cover the retracted feet.

$A . B$. On these two rays can be seen the retracted feet and the vessels running between them.

Towards the mouth more feet are cut off. The tooth-like process in the angle between the two rays has also been removed.

C.D. On these two rays the feet are represented in extended state. Some of them are pointed, others are rounded and show suckers.

$E$. Along this ray the feet are represented in their retracted state. The flattened and rounded processes cover the retracted feet.

\section{Seventh Plate}

This plate shows an orange seastar opened from above, in which the stomach and the blind intestines are visible. The longer spines are removed.

a.a.a. The stomach.

b.b. The two small appendages.

$c$. The white, reticulated layer that is connected to the inner surface of the body wall.

d.d. The stomach veins.

e.e.e.e.e The blind intestine arising from the stomach.

$f . f$. The upper surface of two blind intestines.

g. $g$. The lateral surface of two blind intestines.

$h . h$. The lower surface of two blind intestines.

i.i. Two appendages at the under side of the blind intestine.

$k . k$. Two inflated blind intestines.

l.l. Two blind intestines sectioned longitudinally.

Eighth Plate 
The orange seastar opened fromo above to show the vascular system, the sand canal, the pear-shaped vesicles, the oval vesicles, etc. The thorn and spines on the edge are not shown.

A.B. Two rays still covered by the body wall.

$C$. A ray that shows the skeleton after removal of the blind intestine and the vesicles.

$D$. A ray opened from above in which both blind intestines along with their mesenteries are visible.

$E$. A ray in which the oval vesicles can be seen in contact with the feet after removal of both blind intestines.

$F$. The body wall which covered ray $E$. with both blind intestines.

$G$. The body wall that covered ray $D$.

$H$. The body wall that covered ray $E$.

a.a.a.a. Two blind intestines with their veins from the portion of the body wall $F$.

b.b.b.b.b.b.b.b. The veins of the remaining blind intestines, separated from the blind intestines.

c.c.c.c.c.c.c.c.c.c.c. Veins of the ovaries.

d.d.d.d.d. The circular vein stem, into which the ten veins of the blind intestine and the

ovary terminate.

e.e.e.e.e.e.e.e. The sickle-shaped, sectioned bands that are intercepted by the circular vein stem.

$f$. The folded stomach

g.g. The stomach veins.

$h . h$. The vein stems of the stomach that run inside the hollow sickle-shaped band and terminate in the circular vein stem.

i.i. The sectioned hollow, sickle-shaped band that contains the heart-shaped canal and the sand canal.

$k$. The heart-like canal, into which the circular vein stem terminates.

$l$. The artery arising from the heart-like canal.

$m$. The sand or stone canal that terminates in the circular canal that surrounds the mouth.

$n$. The ring canal opened at one part.

o.o.o.o. The paired brown, hollow, gland-like bodies that open into the ring canal. Only nine gland-like bodies are seen in the drawing as one is removed.

p. Cross-section of the esophagus separated from the stomach along with the oral opening and the tooth-like processes located around it.

q.q.q.q.q.q. The pear-shaped, hollow vesicles with their hollow stems. They terminate in the ring canal around the mouth between the brown, hollow glandular bodies. Some of these pear-shaped vesicles are shown in their contracted state.

r.r. Two of the blind intestines in their location in ray $D$.

s.s.s. The cross-sectioned mesenteries of each blind intestine shown here as two opened plates.

t.t.t.t.t.t. The paired hollow, oval vesicles that connect to the feet. Visible on ray $C$. is the skeleton.

$u . u$. The bodies of two of the vertebrae.

v.v.v.v. The transverse processes

$w . w . w . w$. The diagonal processes.

x.x.x.x. The holes through which the feet connect to the vesicles.

$y . y . y . y$. The transverse pieces lying along the vertebrae. 
z.z. In ray $C$. are two white, tendon-like fibers or bands that arise from the vertebral column and insert in the stomach. These have been considered incorrectly as nerves.

A tendon-like band that inserts into the stomach.

_._-_. The ovaries lying in an angle and attached to the inner surface of the body wall. The other ovaries are not shown.

-._-.. The spaces or clefts in the fibrous body-wall through which water enters the cavities of the ray through the respiratory tubules.

\section{Ninth Plate}

Seen on the under surface of the seastar in Figure 1 is the ring vessel around the mouth that is a process of the vessel arising from the heart canal.

a.a. The vascular ring around the mouth including the five branches which run towards the body cavity of the sea star.

b.b.b.b.b. Locations where the ten tooth-like processes are removed to show the entrance of the five vascular branches.

c.c. An orange-yellow vessel lying between the removed feet. It arises from the orange-yellow vessel that forms a circle around the mouth.

the feet and their vesicles.

e.e. The two calcareous pieces that form the body of a vertebra.

$f . f$. The two longitudinal pieces that attach to the transverse process of a vertebra.

g.g. The lower calcareous pieces that carry four to five thorns or spines.

$h . h$. Calcareous pieces on the edge of the ray.

i.i. Calcareous pieces that carry the flattened, rounded processes that can cover the retracted feet.

$k . k . k . k$. Lower calcareous pieces where the rounded tubercles are discernable after the spines were removed to which the spines were attached.

Figure 2. represents the nervous system. It is on the under surface of the seastar; the vessels have been removed.

a.a.a. The nerve ring around the mouth.

$b . b$. Branches that enter the body cavity through the holes of the first pair of feet.

c.c The general location of the nervous branch between the feet removed here.

\section{LEGENDS TO THE ILUSTRATIONS}

$\mathrm{OF}$

\section{THE STRUCTURE OF THE STONE SEA-URCHIN}

\section{Tenth Plate}

Figure 1. shows a specimen of the stone sea-urchin opened along its side and separated. The lantern, the intestinal tract and the vascular system of the intestinal tract are shown. 
$A$. The lower half with the lantern.

$B$. The upper half.

$a$. The small intestine arising from the lantern.

$b$. The small intestine turning into the large intestine.

$c$. The blind end of the large intestine.

d.d.d.d. The first main coil of the large intestine.

e.e.e.e.e. The second main coil of the large intestine.

$f$. The rectum.

$g$. The ring vessel that surrounds the mouth.

$h$. The vein stem arising from the ring vessel thatt has been separated from the test.

$i$. The heart-shaped canal.

$\mathrm{k}$. The vessels arising from the heart-shaped canal that continue along the inner surface of the intestinal tract.

l.l.l.l.l. The artery running along the surface of the intestinal tract whose branches continue towards the walls of the intestinal tract.

m.m.m.m.m.m. The vein running along the outer edge of the intestine tract which picks up a branch on one side of the intestinal canal and sends off a branch on the other side to the membrane found on the inside of the test.

n.n.n.n. Vessels that arise from the ovaries and the membrane that lines the test.

o.o.o.o. The oval, fluid-filled vesicles.

p.p. Muscles that connect the semicircular pieces of the Aristotle's lantern.

q.q.q.q.q. The five ovaries.

r.r.r.r.r.r.r.r. The canal that is connected with the hollow feet by side branches.

Figure 2. The so-called lantern can be seen from the inside as well as the lower half of the test. a.a. The semicircular process..

b.b.b.b.b. Muscles that arise from the inner side of the semicircular pieces and attach to the outer side of the small pyramids.

c.c.c. Semicircular, Y-shaped pieces.

d.d.d. Muscles that attach to the tips of the semicircular pieces.

e.e.e.e. Muscles that connect the semicircular pieces to each other.

f.f.f.f.f. The distended oval vesicles that connect with the five canals.

g.g.g. The canals whose side branches continue through the holes in the test into the hollow feet.

$h . h$. Rows of holes to which the feet are connected. The fluid necessary to extend the feet can be transported through these holes by the side branches of the canals.

i.i.i.i. Pieces of a large triangle of the test.

Figure 3. The test seen from the inside; the lantern has been removed.

$a$. The mouth opening.

b.b.b.b.b. The five arched processes.

c.c. Holes through which seawater can enter the test through the respiratory tubules.

d.d.d.d.d. The five canals arising from the five small pyramids that are connect to the oval vessicles.

e.e.e.e.e. The openings in the arched processes through which run the canals.

f.f.f.f.f. The five canals from which side branches arise that transport a clear fluid into the feet. 
g.g.g.g.g. The holes in the five small triangles through which the side ranches continue into the hollow feet.

$h . h . h . h . h$. The hollow feet connected to the holes.

i.i.i.i. The round nipples or cupules in which the feet end.

k.k.k.k. Spines.

l.l.l.l. The whitish membrane that connects the spines to the rounded tubercles.

m.m.m. The round tubercles of the test.

n.n.n.n.n.n. Pieces of the large triangle of the test.

$o$. A spine separated from the test.

Figure 4. The lower half of the test with the ovaries.

a. The intestine.

b.b.b.b. Ovaries.

c.c.c.c. The five exits of the ovaries, or the five ovarian tubules.

d.d.d.d. Four canals with their side branches.

e.e. A canal with its branches was removed here, which reveals four rows of holes

through which the side branches continue into the hollow feet.

Figure 5.

a. The round mouth opening with the five teeth lying in it.

b.b.b.b.b. The small, soft processes with their round nipples.

c.c.c.c.c. Thread-like appendages that end with three small points.

d.d.d.d.d.d.d.d.d.d. The ten branches respiratory tubules through which water is taken up into the test.

e.e.e.e.e. Rows of holes to which the feet are connected.

f.f.f.f.f. The rounded tubercles to which the spines are connected.

Figure 6. A small triangle of the test composed of forty-eight pieces.

a.a.a.a. Pentagonal pieces of the test.

$b . b$. The two lower, slightly turned pieces that form an arch-like process.

c.c.c.c. The ten holes lying in two rows and the pentagonal pieces; two of these holes lead to a foot.

Figure 7. A large triangle of the test composed of thirty-eight pieces.

a.a.a.a. Pentagonal pieces with their rounded tubercles.

b.b.b. The serrated edges.

Figure 8. The ring around the anus opening.

a.a.a.a. Larger pieces to which the tips of the large triangle connect.

b.b.b.b.b. The five holes in which are found the gonoducts of the ovaries.

$c$. The largest piece that covers the heart-shaped canal.

d.d.d.d.d. The five smaller pieces to which the tips of the small triangle connect. 
Plate 1

Hototheren enbulofa.

Erfte Tafel

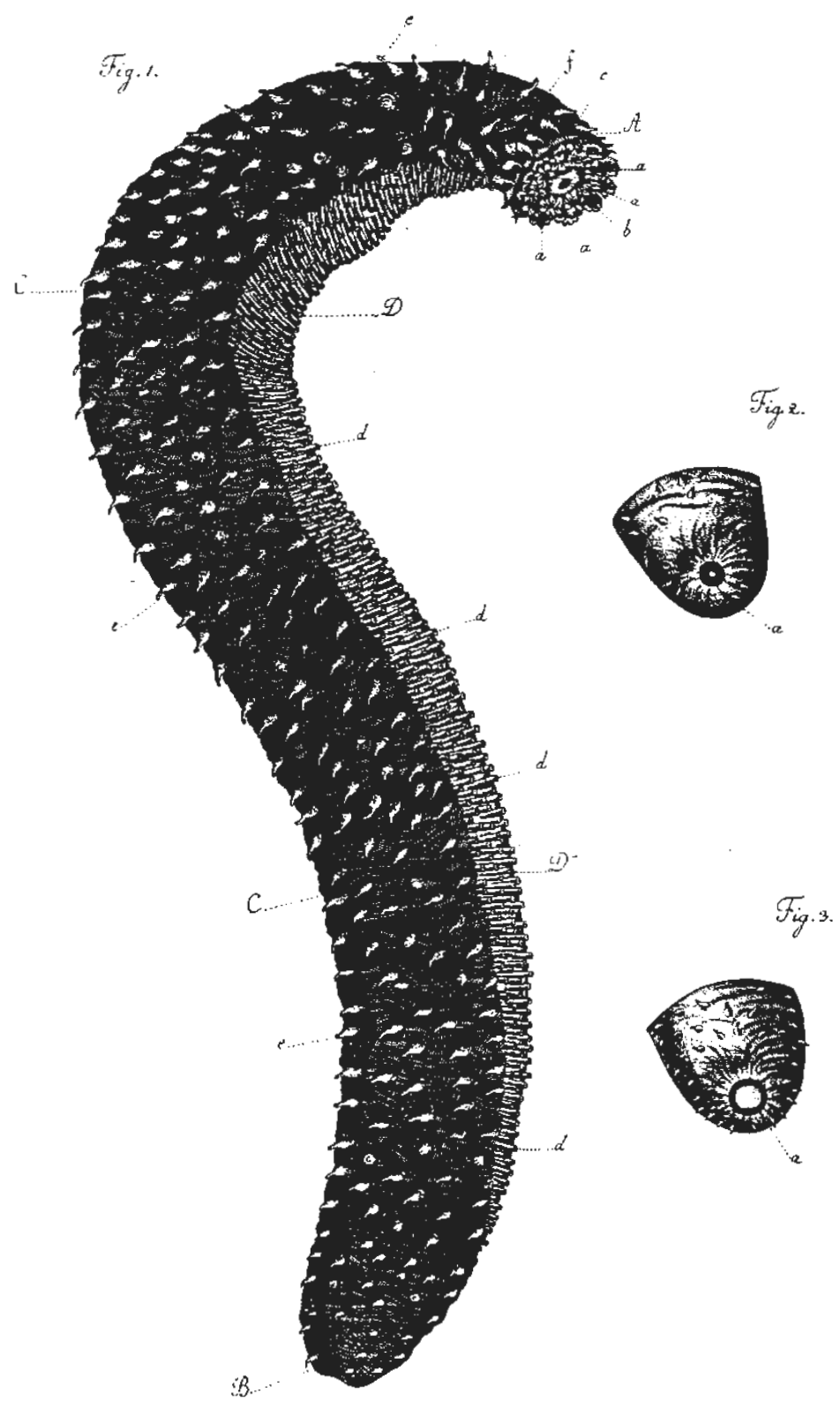

Dactom Nling delin.

Writuert seulpos. Aorrib. 
Tolothuria tubulo/a.

Erfte Yafel.

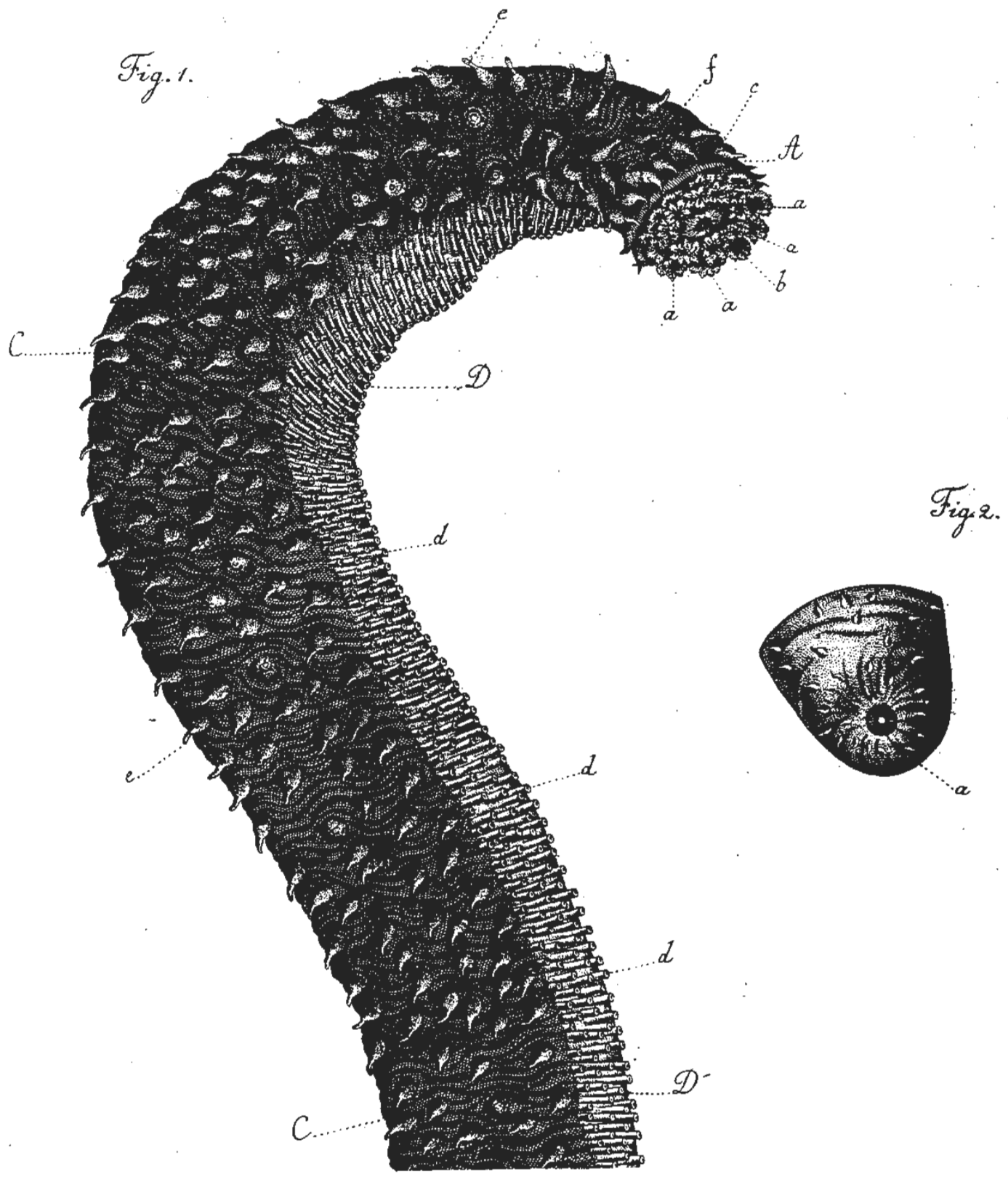




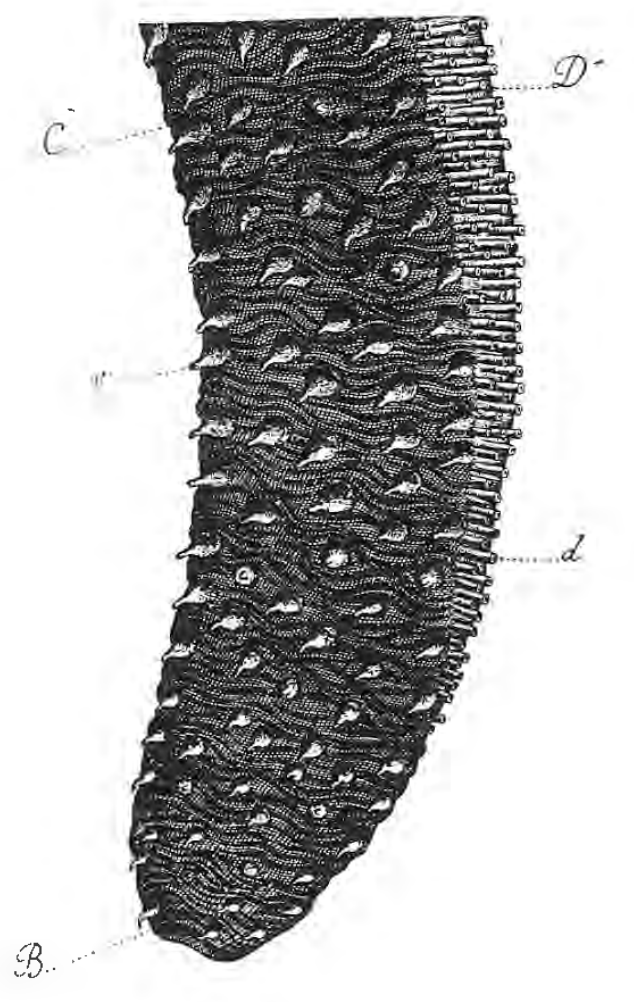

Fig. 3.

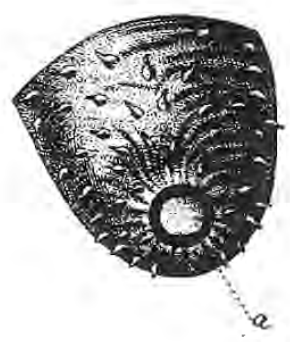


Plate 2

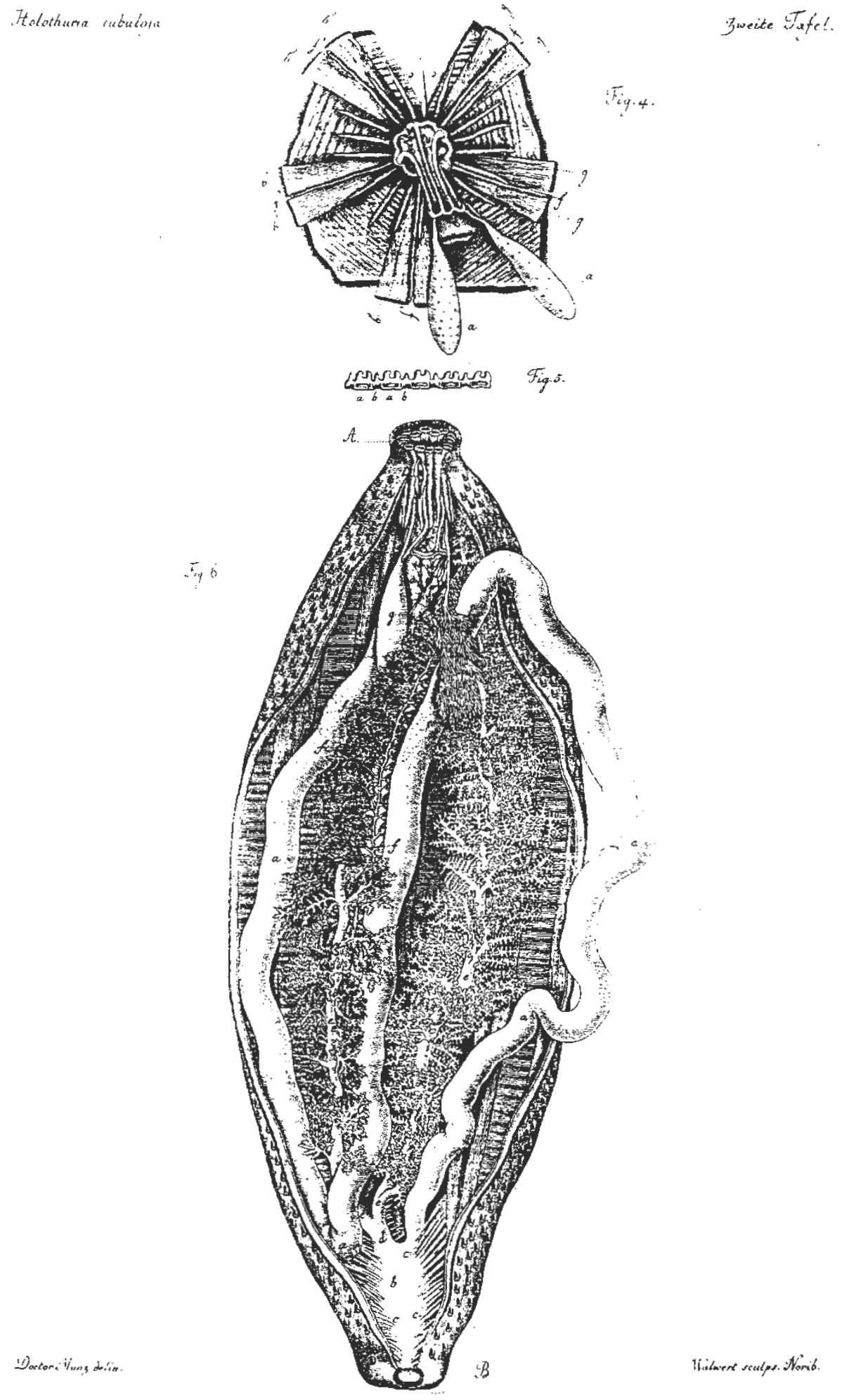




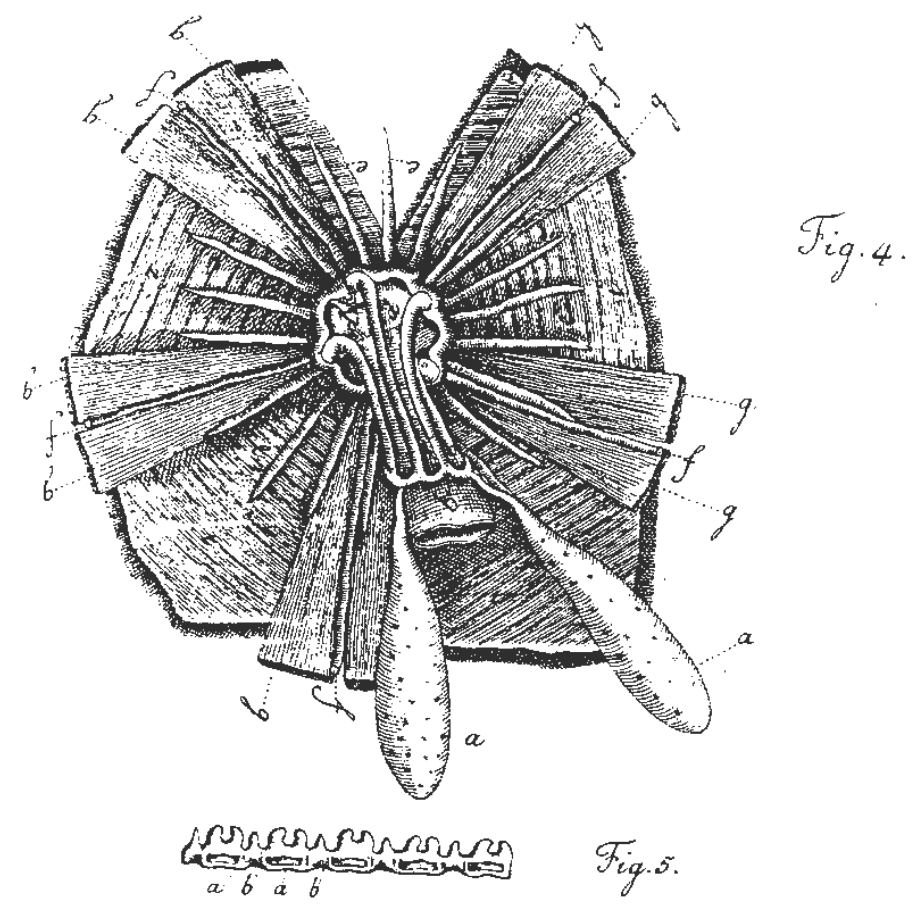




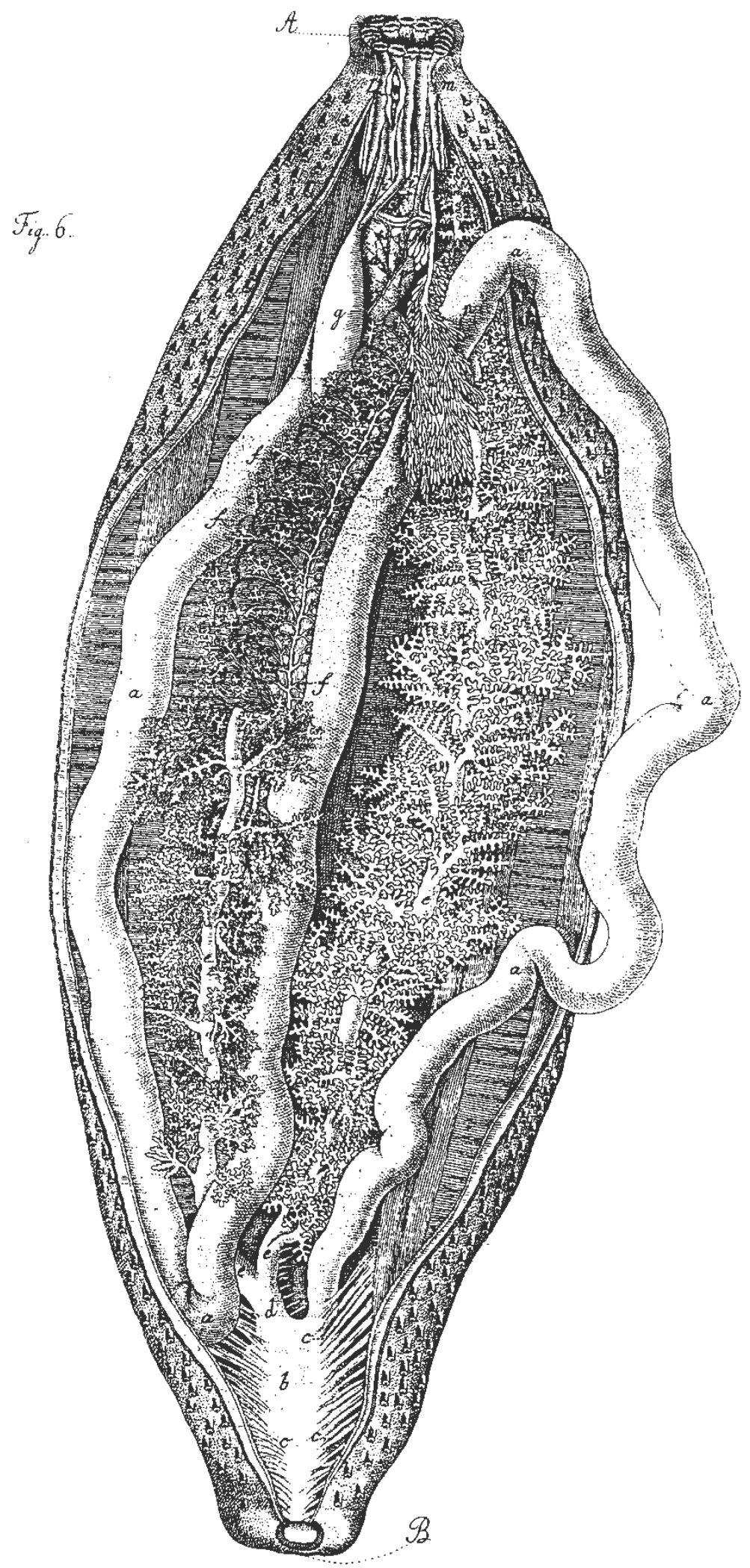


Plate 3

Hotothunas aroutalia

$D_{\text {ritte }} T_{a f e l}$

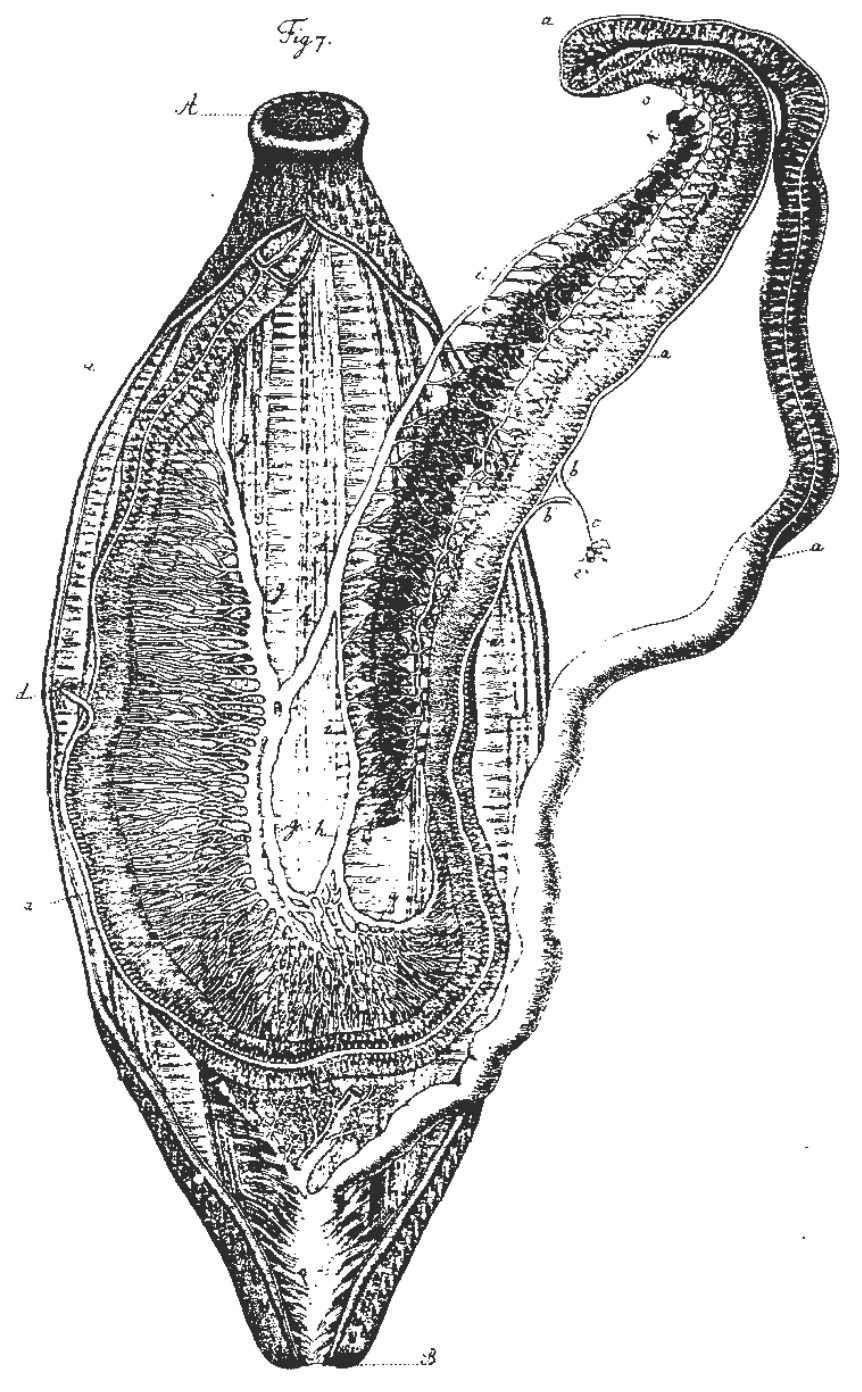

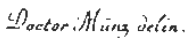

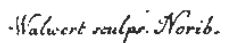




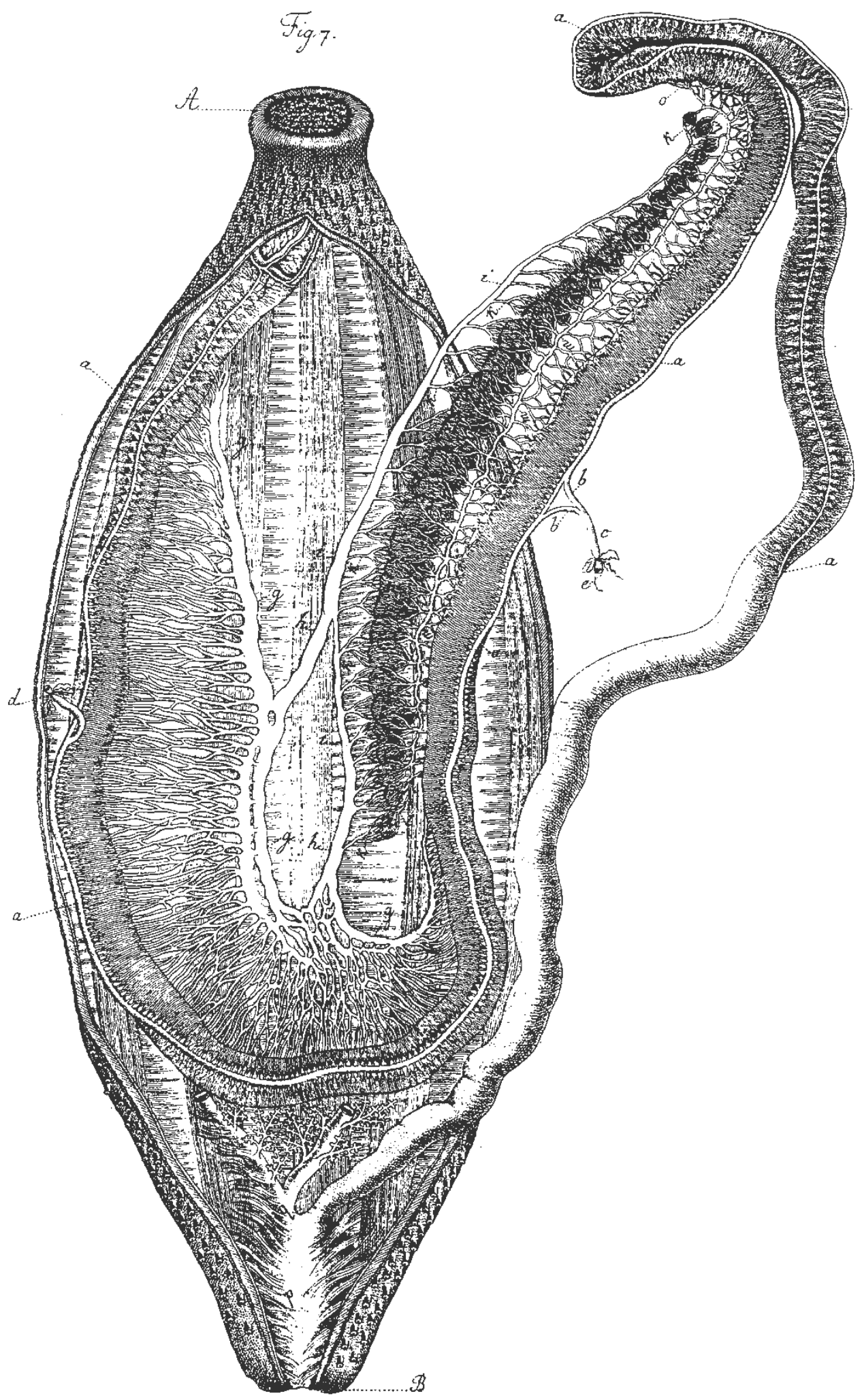




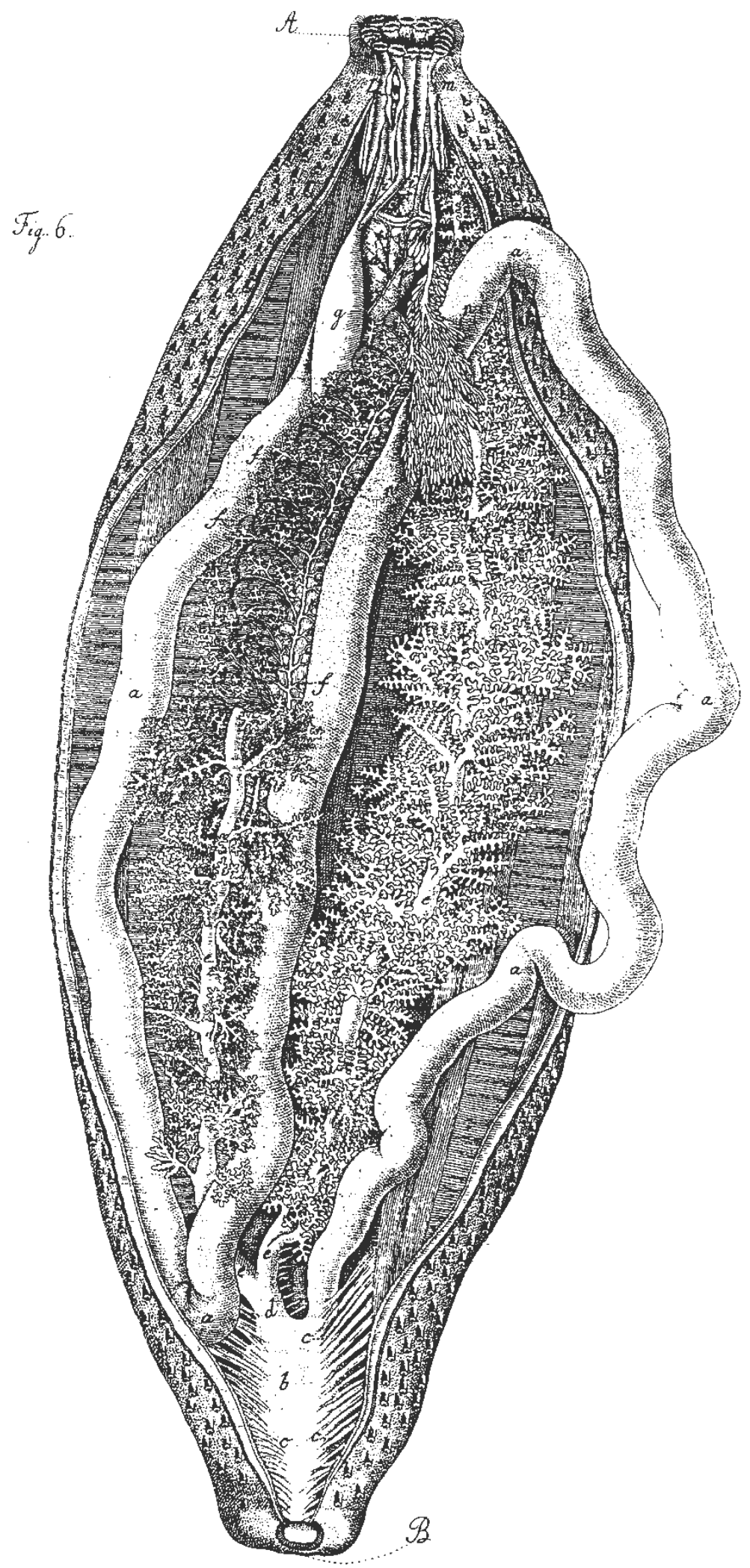


Plate 4

Holothume tubuloir

Luevte Dafel.

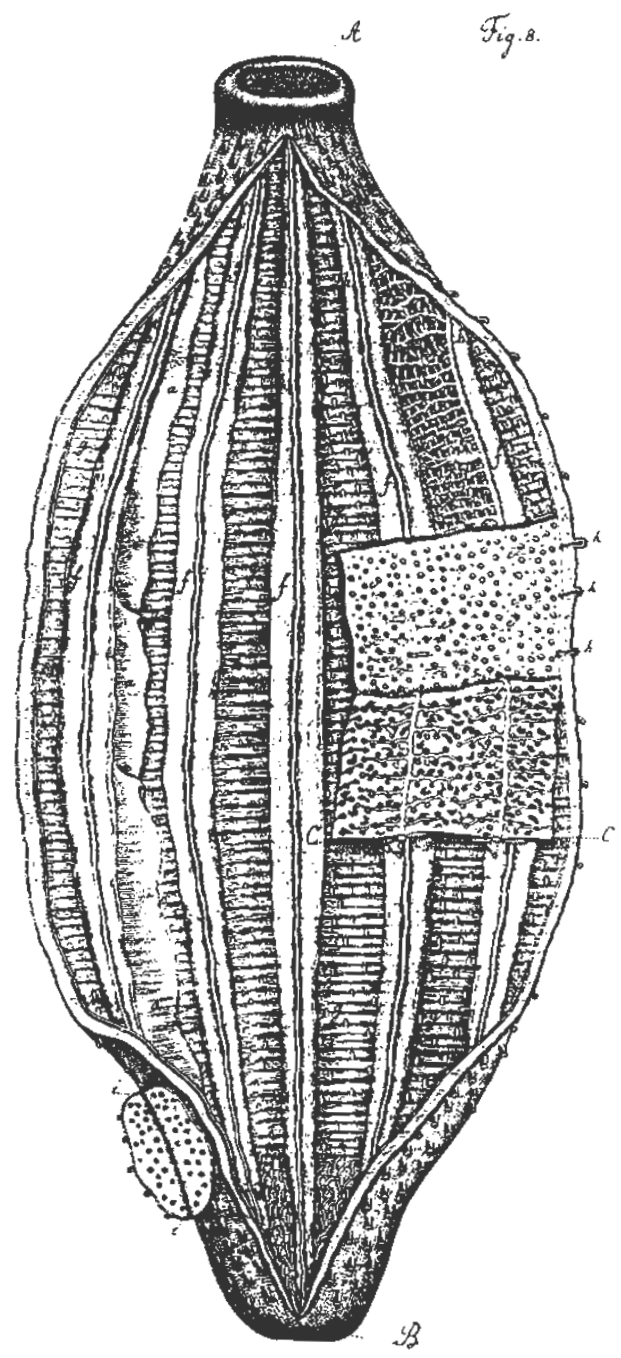

Liortom Shlün, delin.

Haluser sculpr. Norib. 


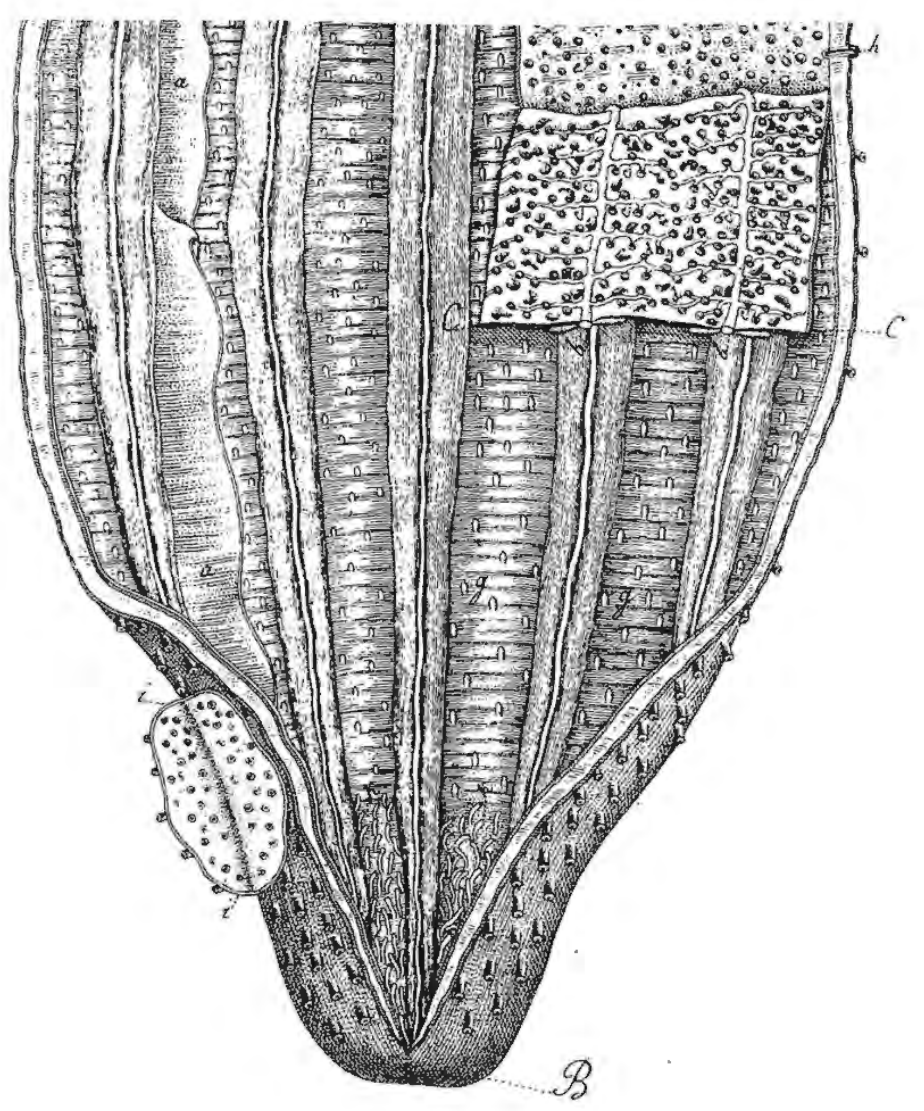

Wabuert sculps. Norib. 
Plate 5

Htemers arranciara.

Funfte Tufei:

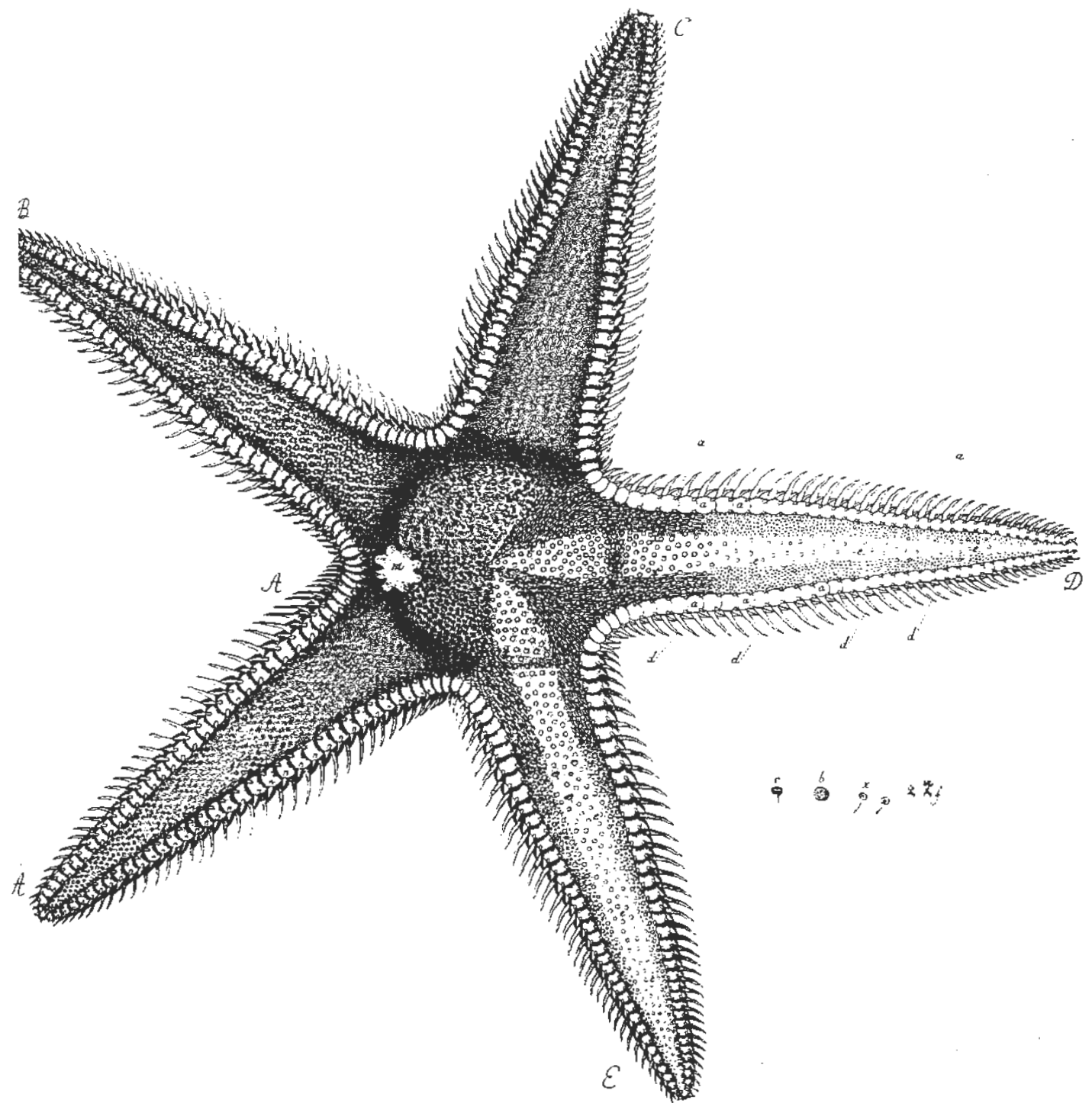

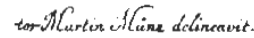

*. S. \%hetwert seulpoit. 


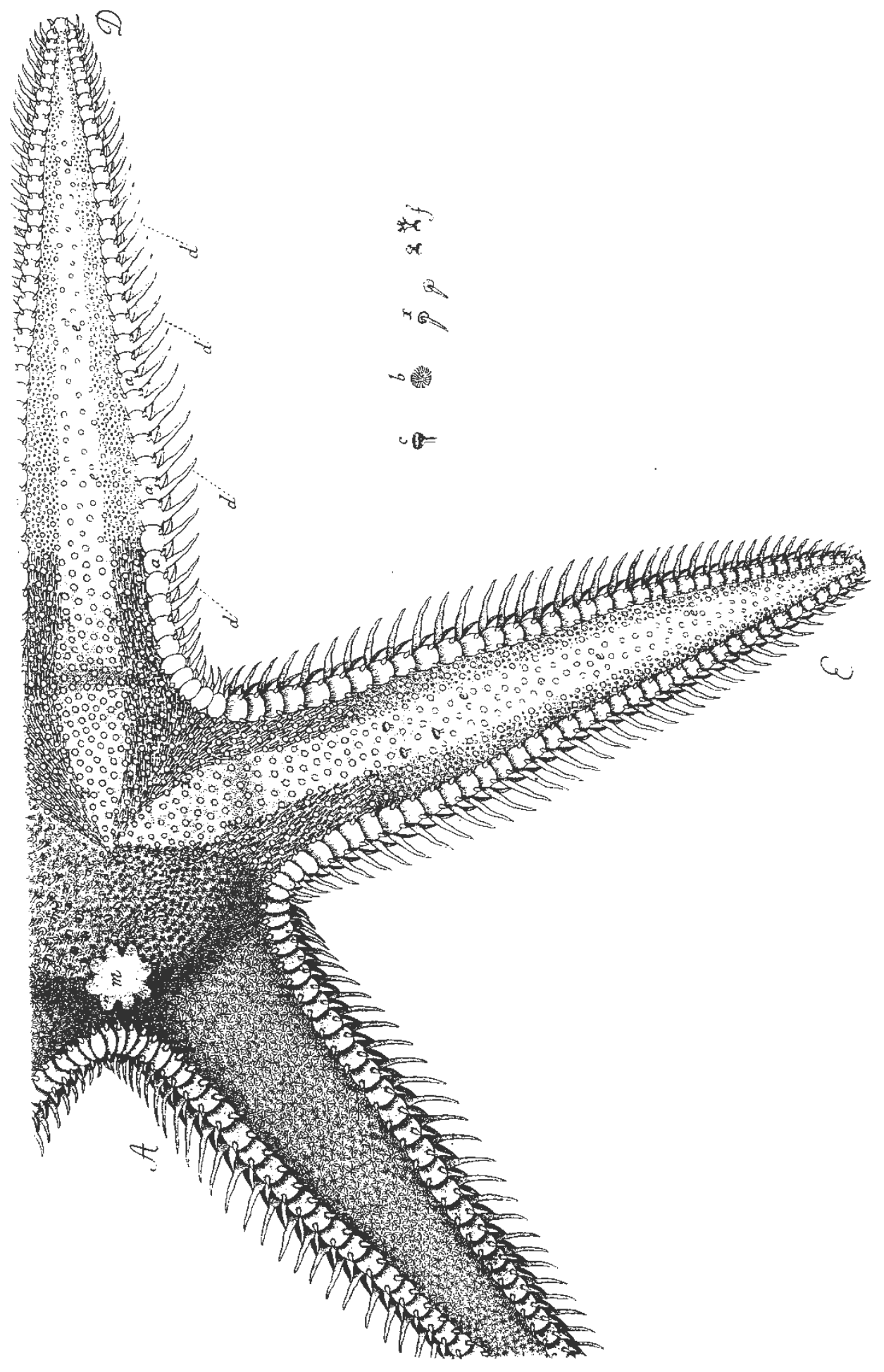


Plate 6

Afterias aranciaca.

Sechfte Tafal.

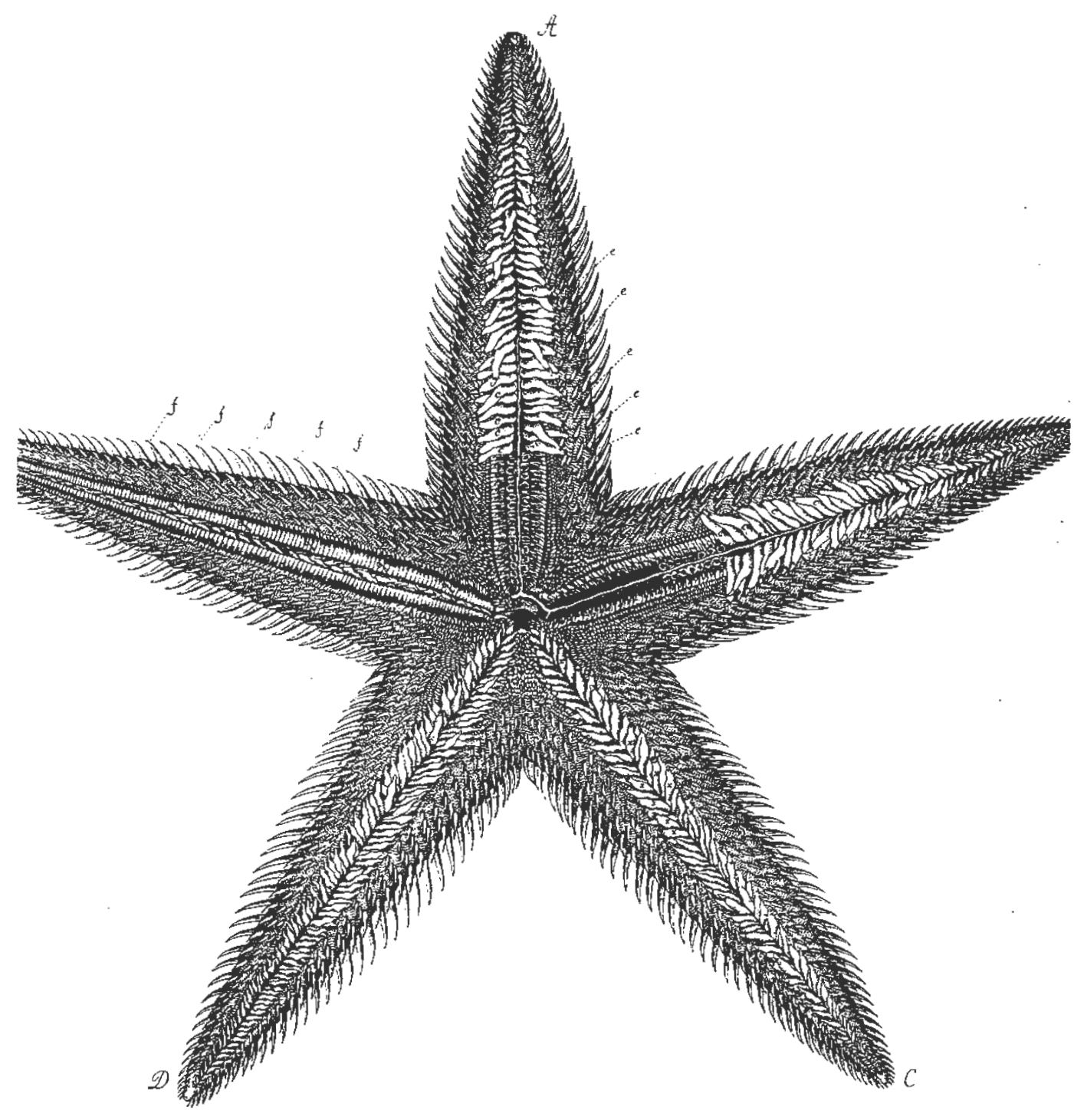

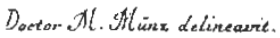

I. S. Wrature recularit 


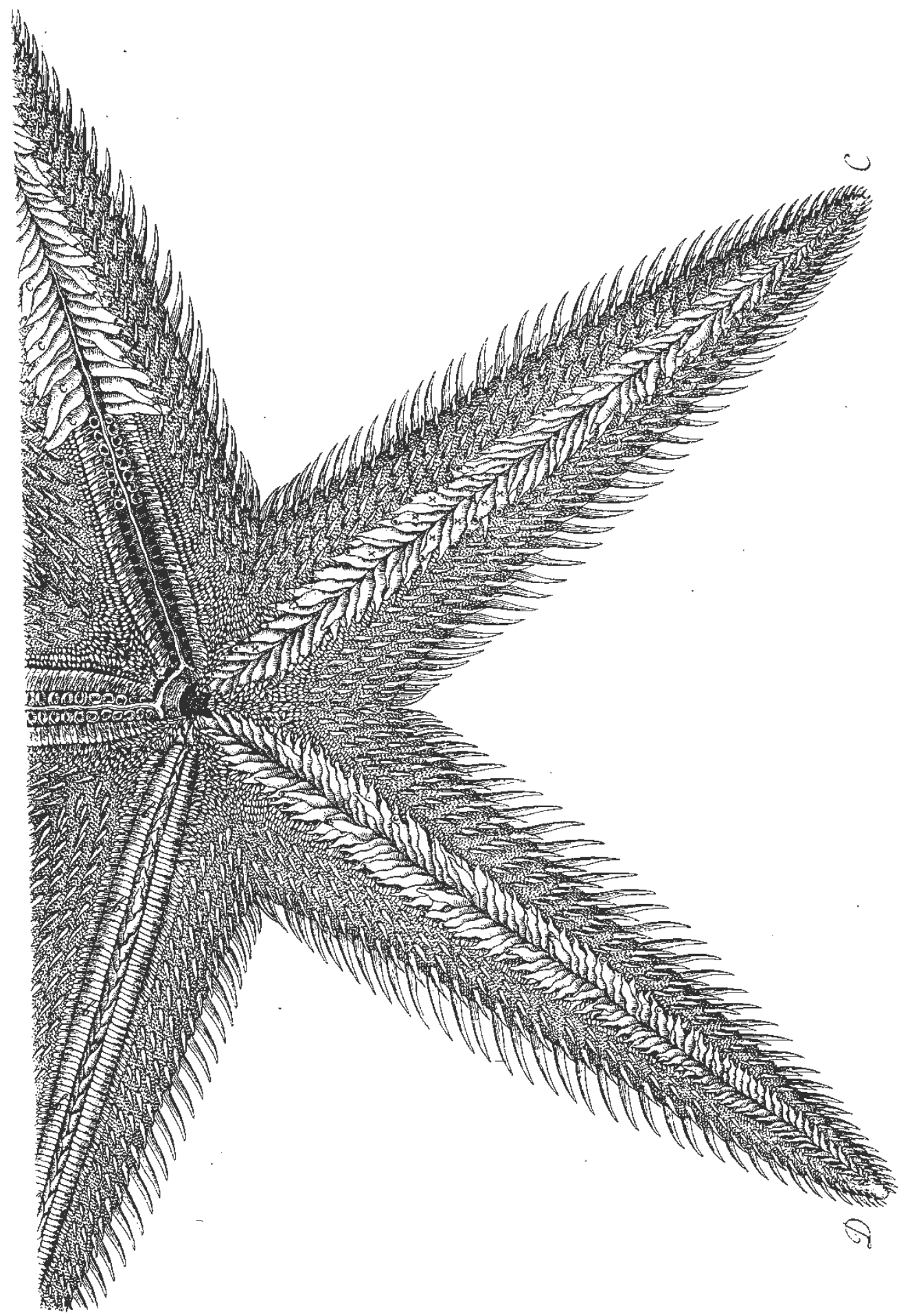


Plate 7

H/terias amnciaca

cliebente Tafel.

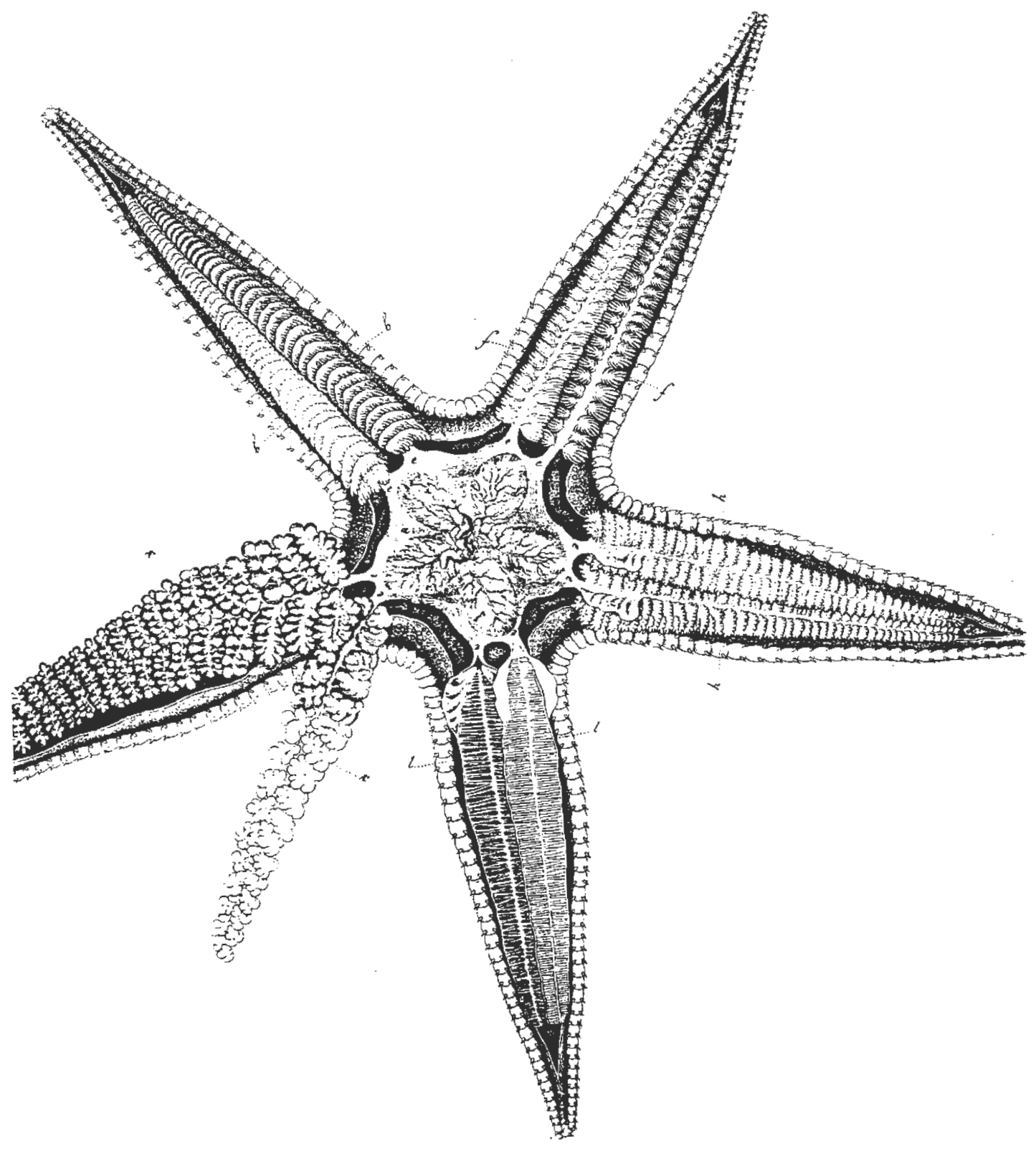

J. S. Wratwert scutprit

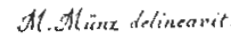




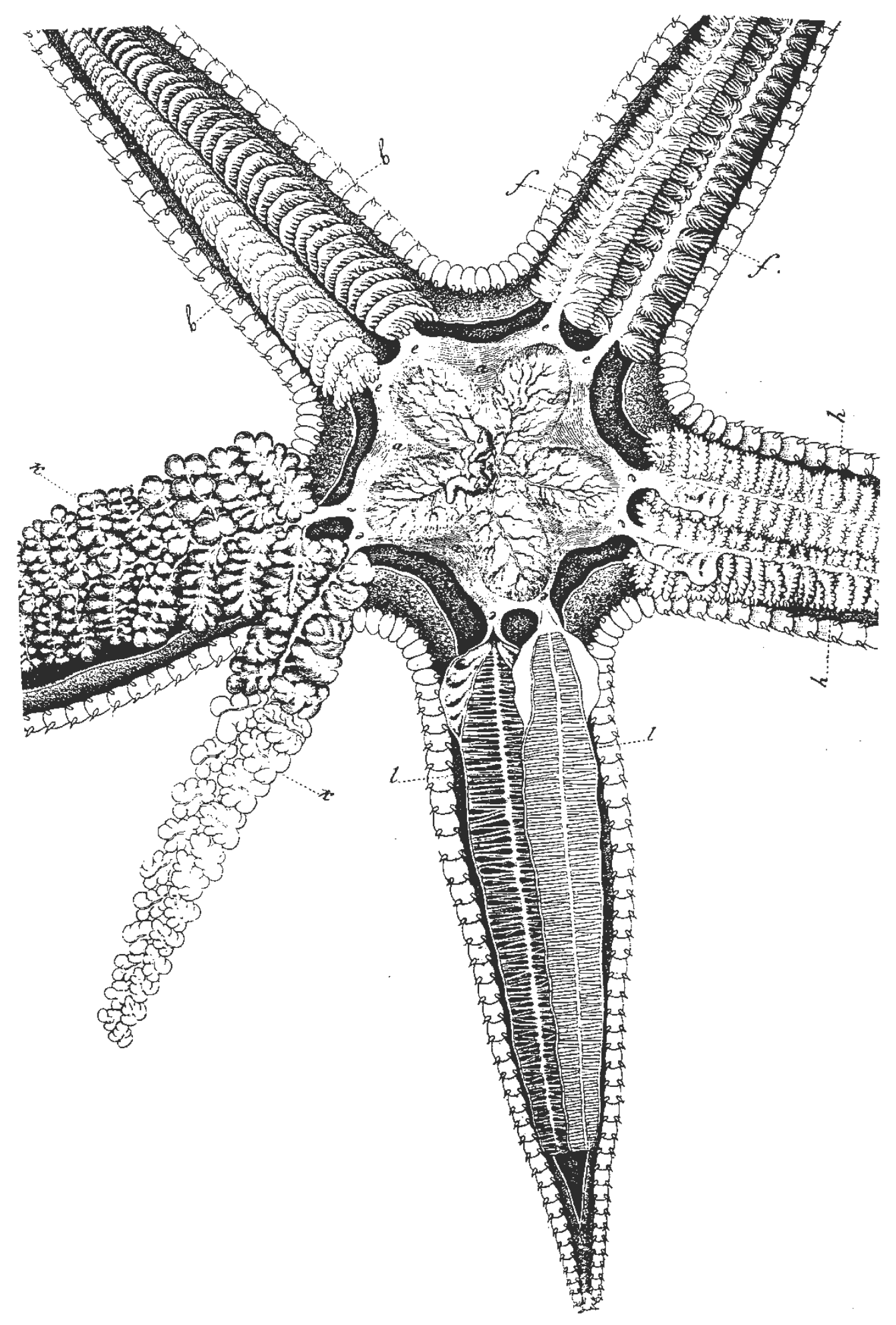


Plate 8

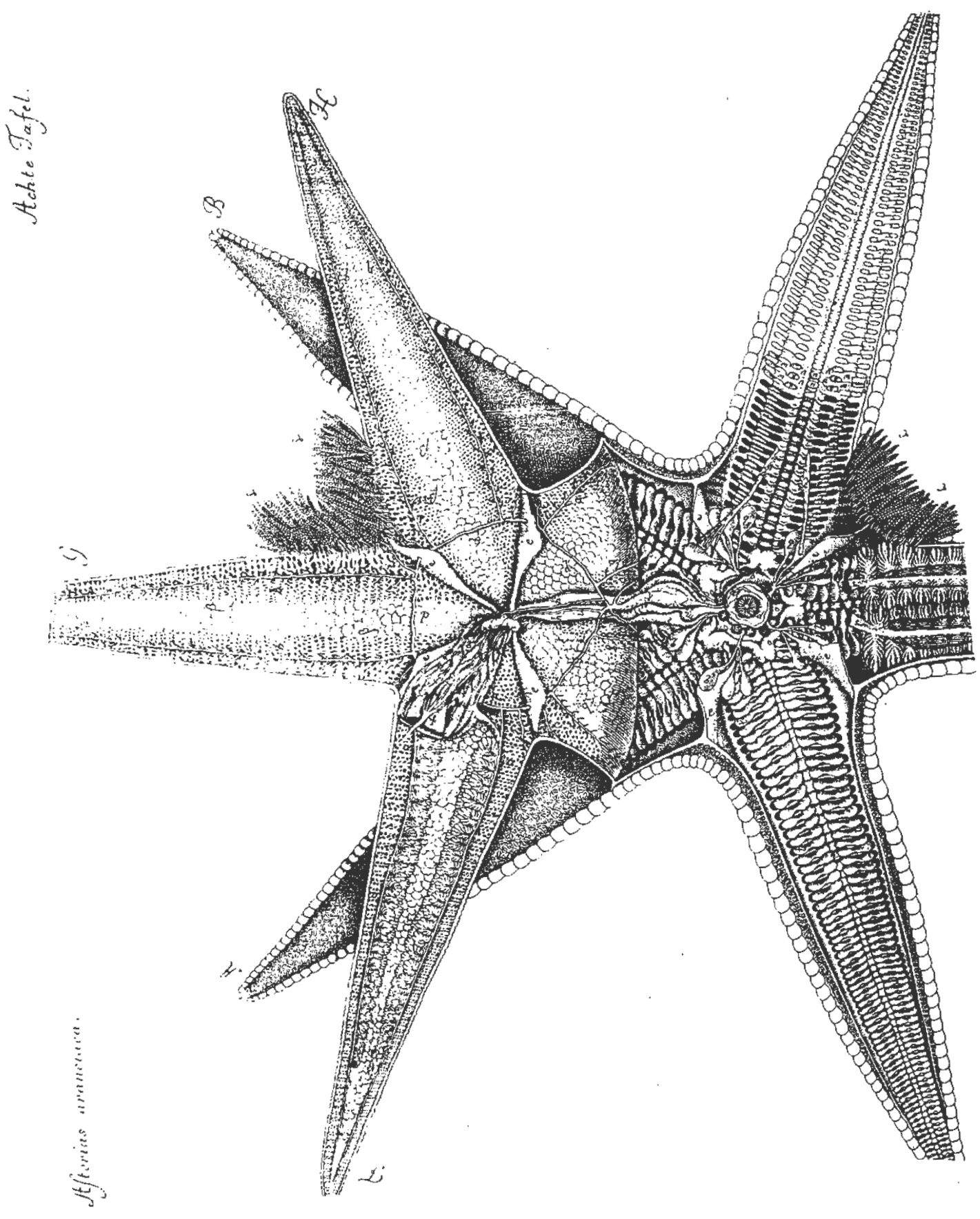




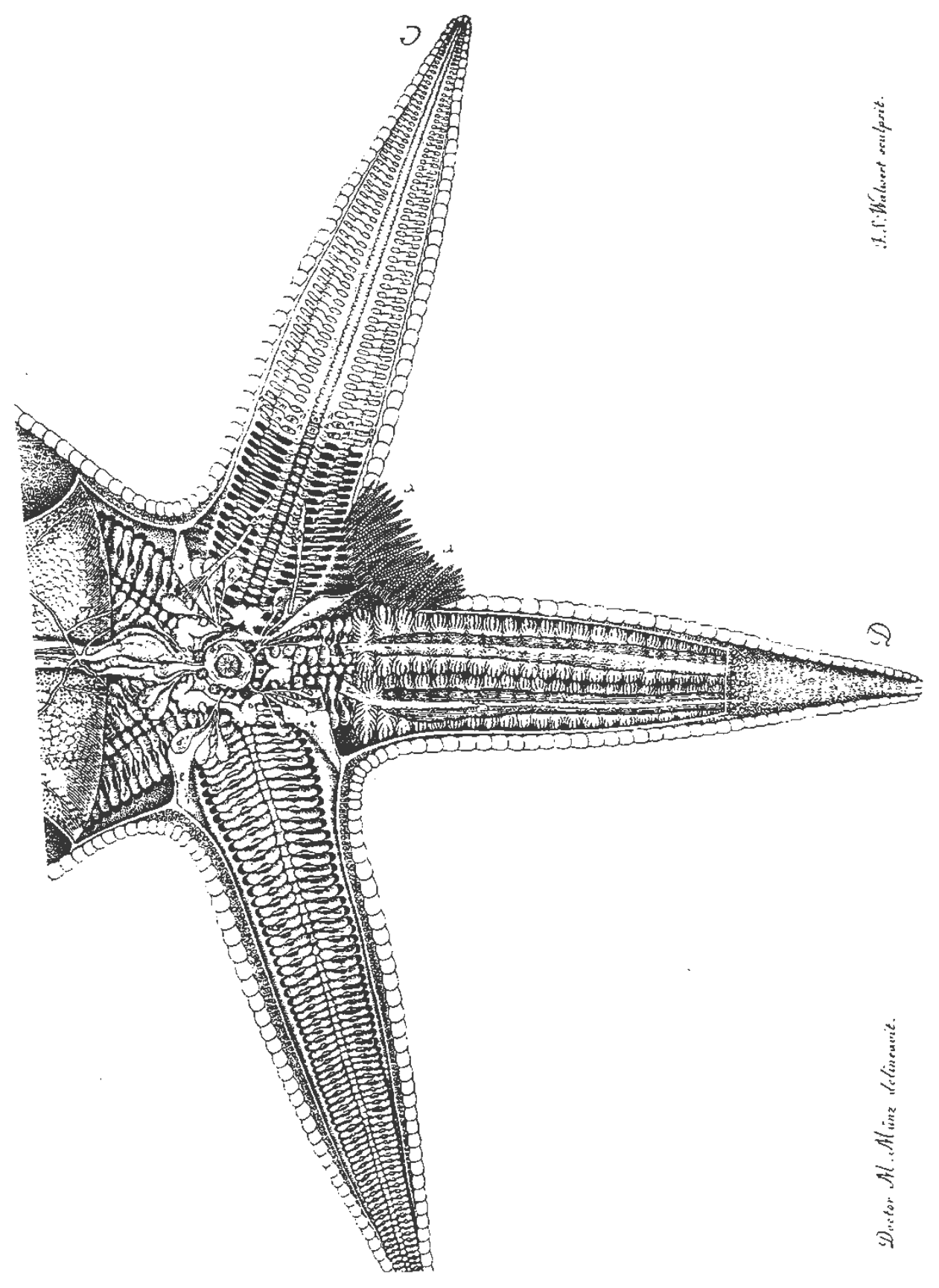




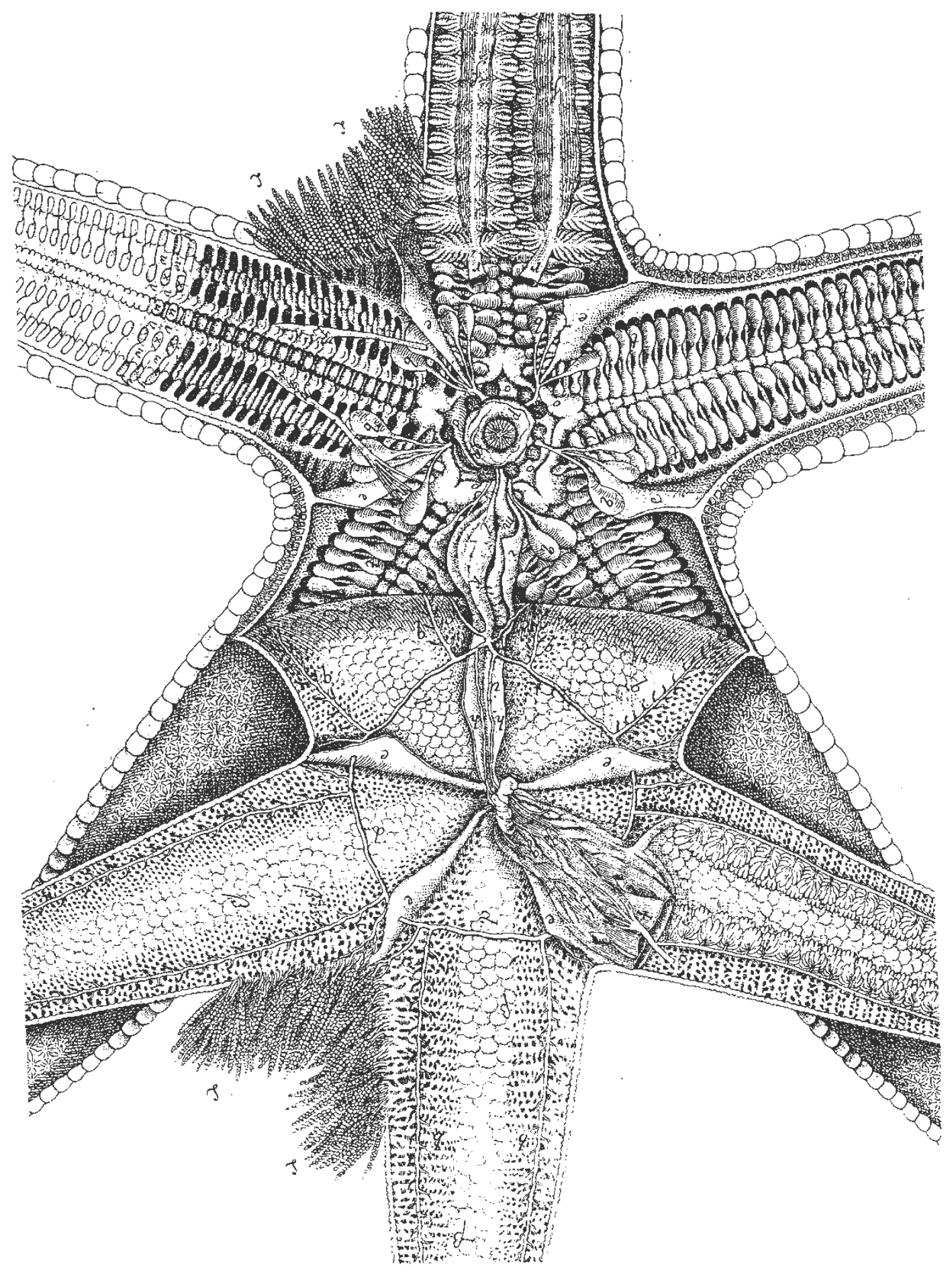


Plate 9
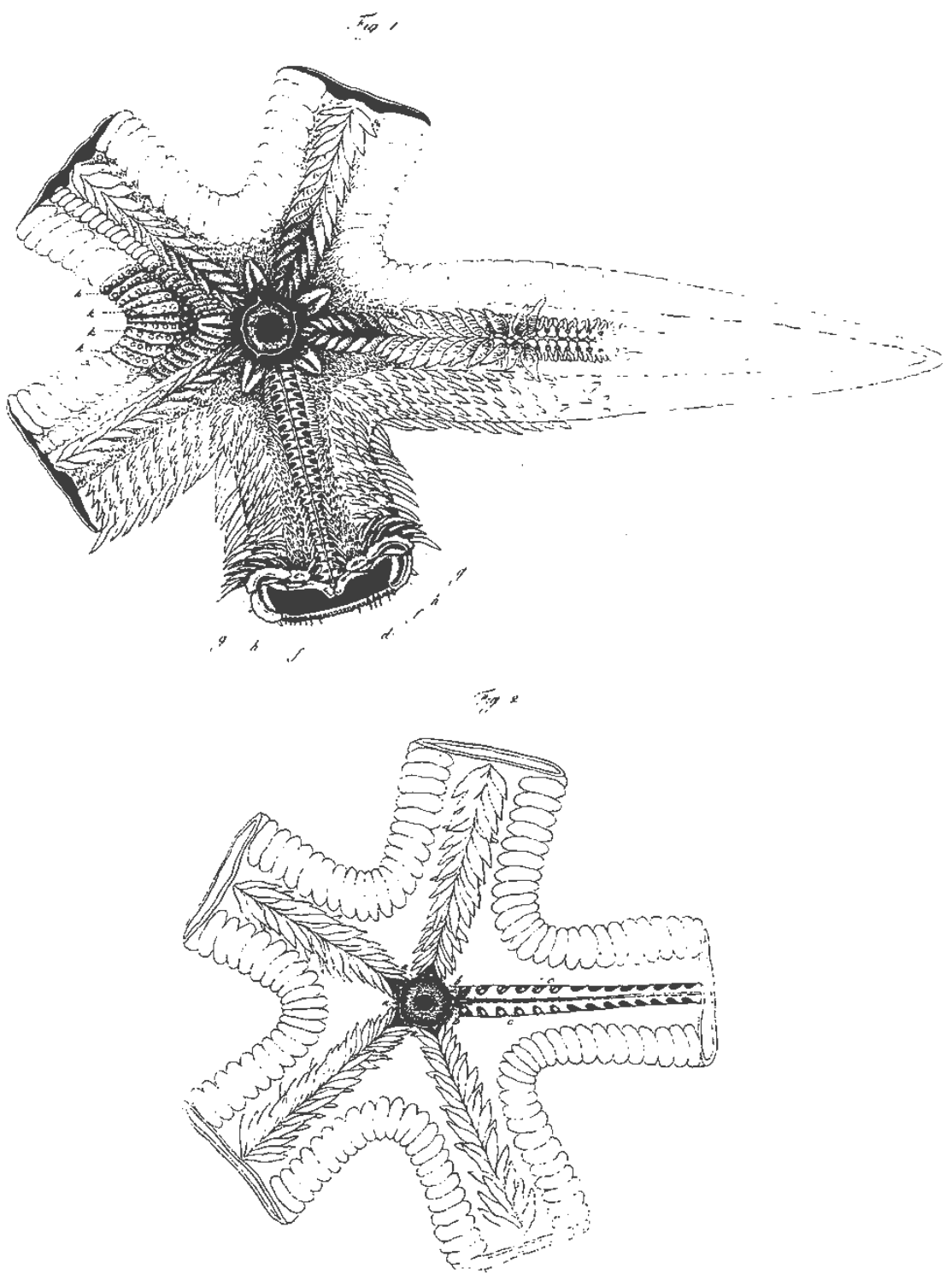


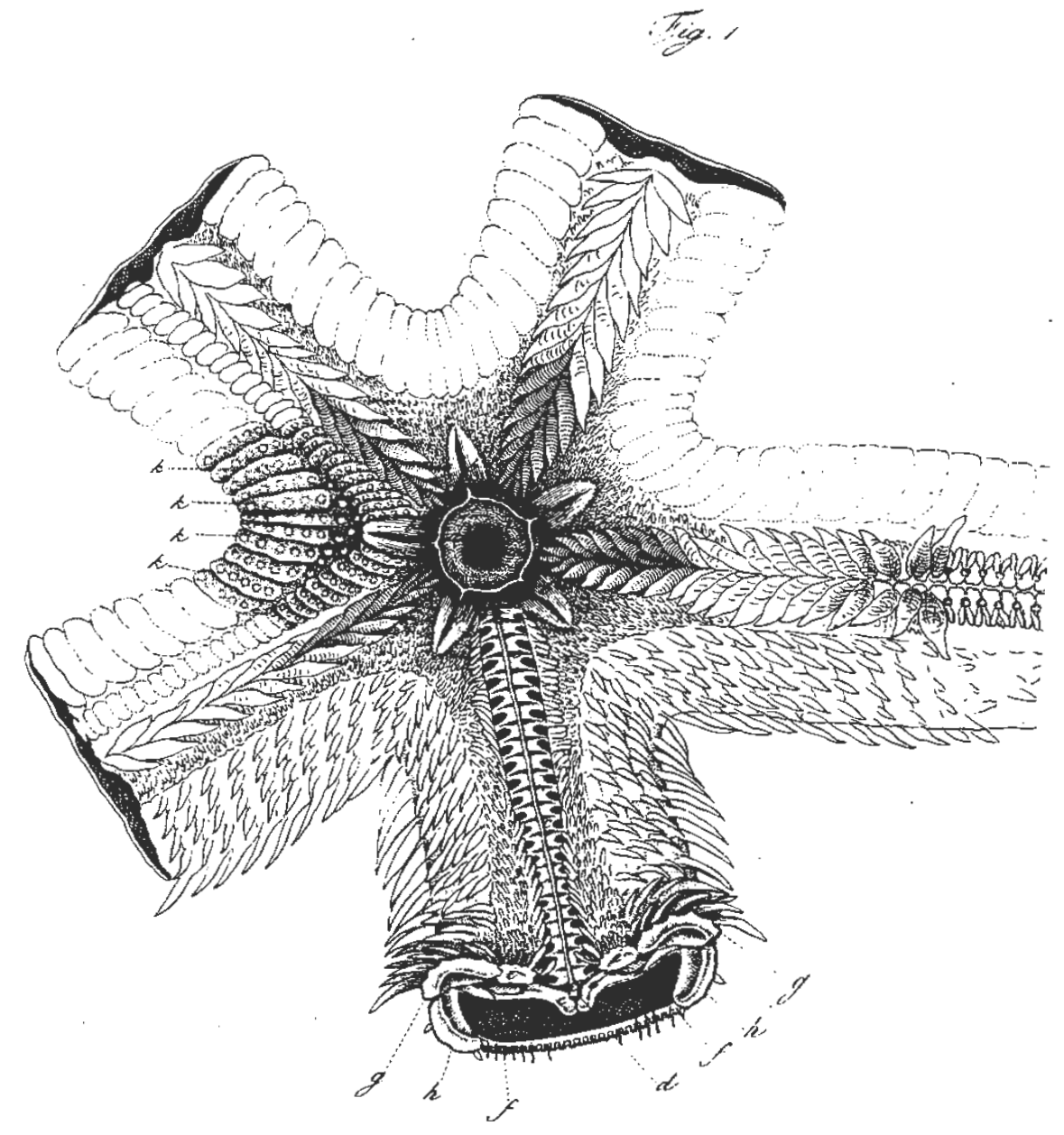




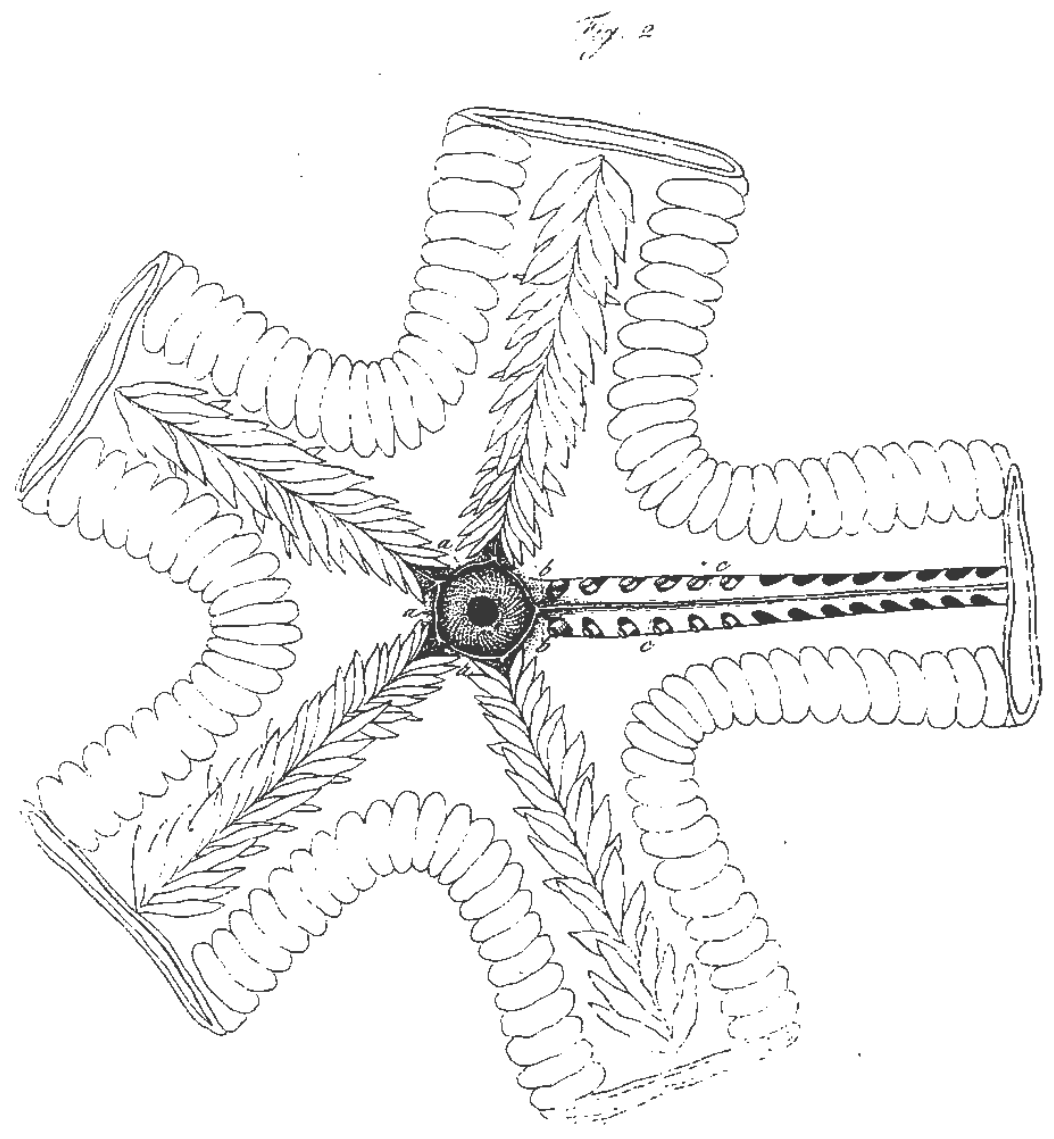




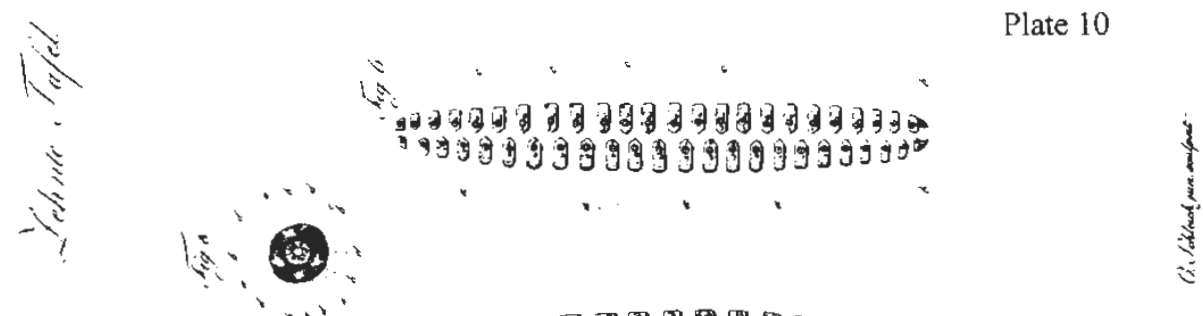

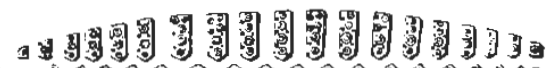

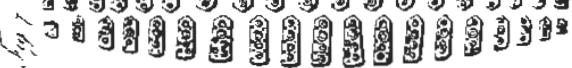
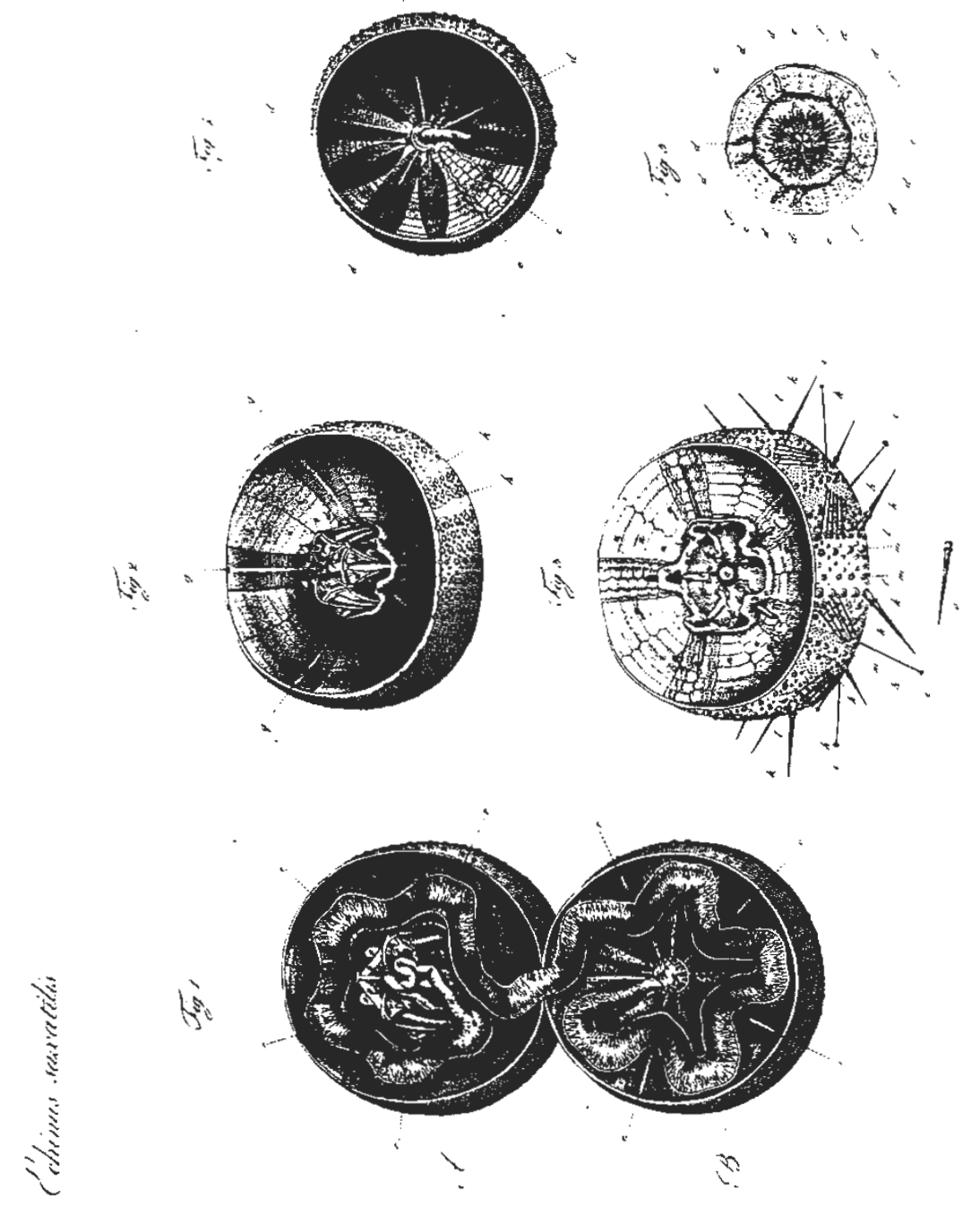


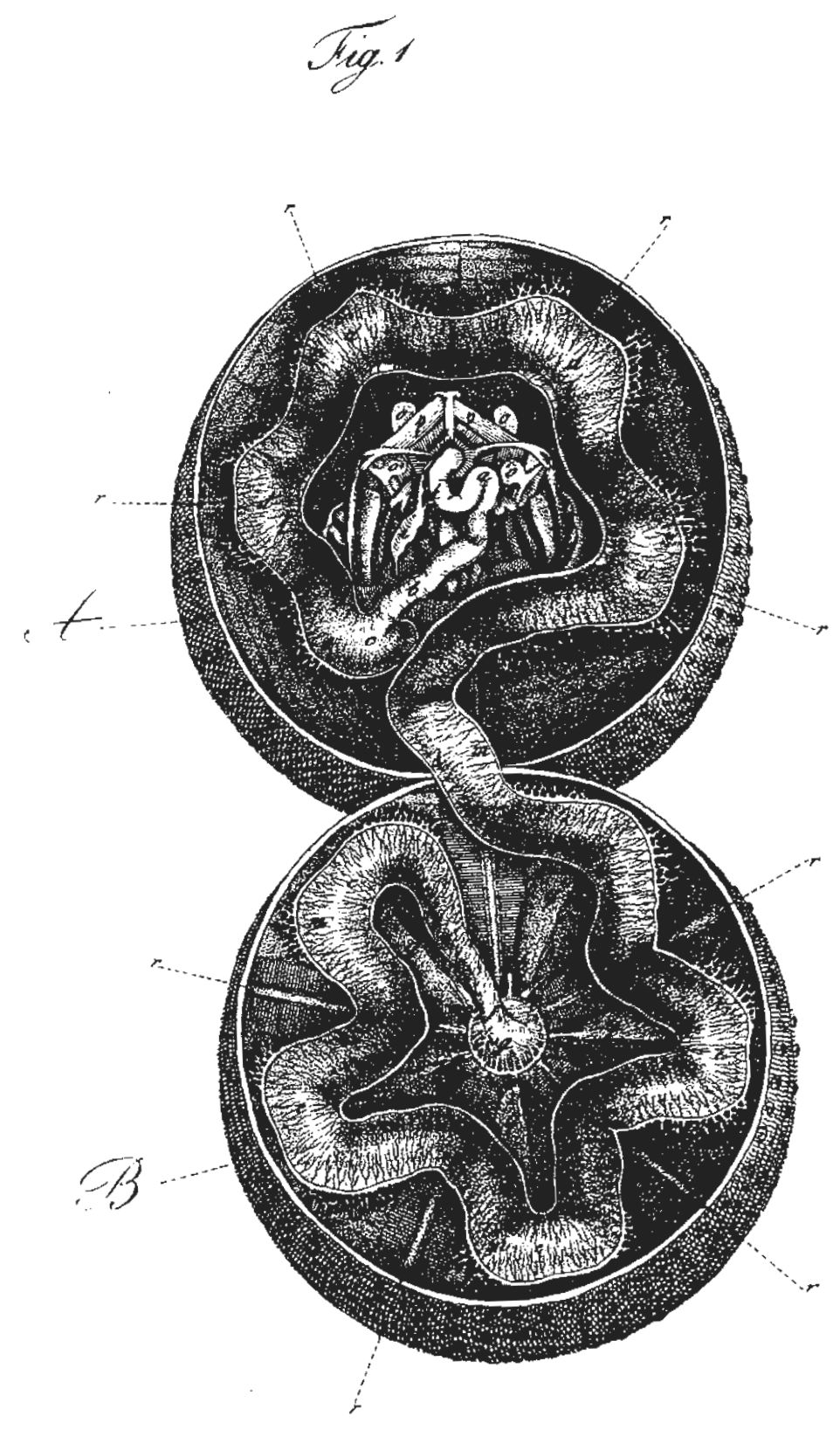




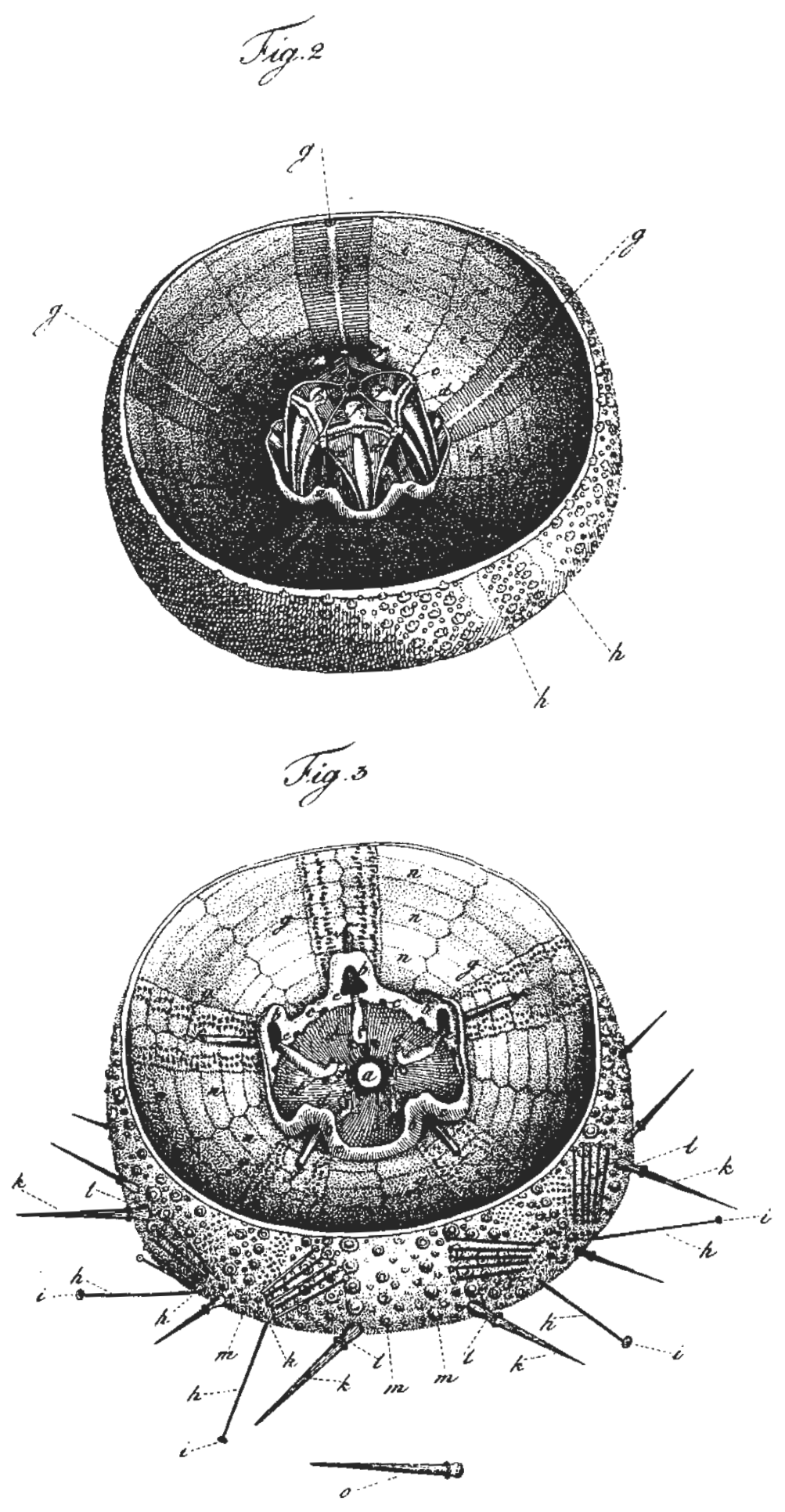




\section{$\sqrt{\operatorname{lig} x}$}
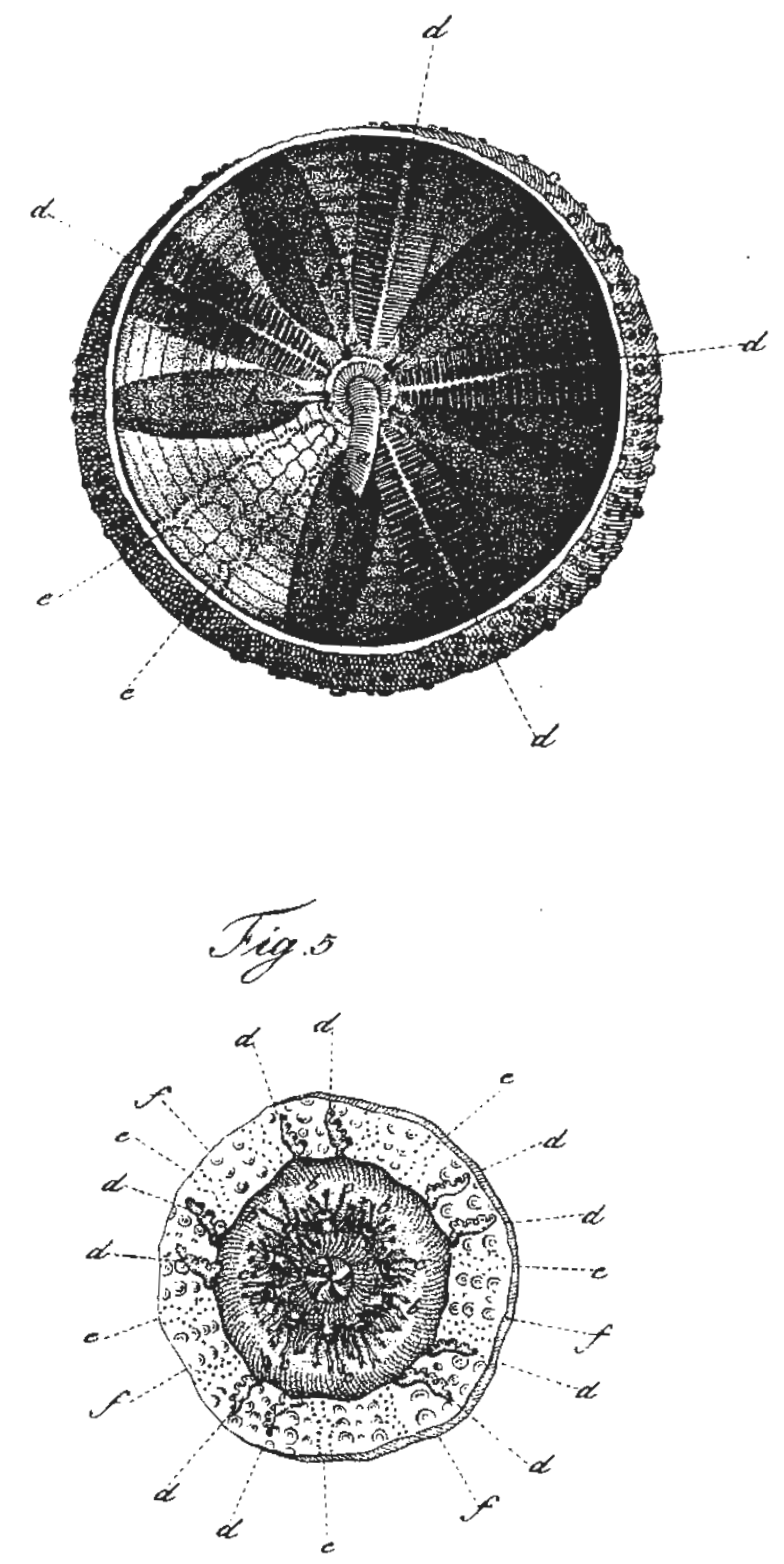


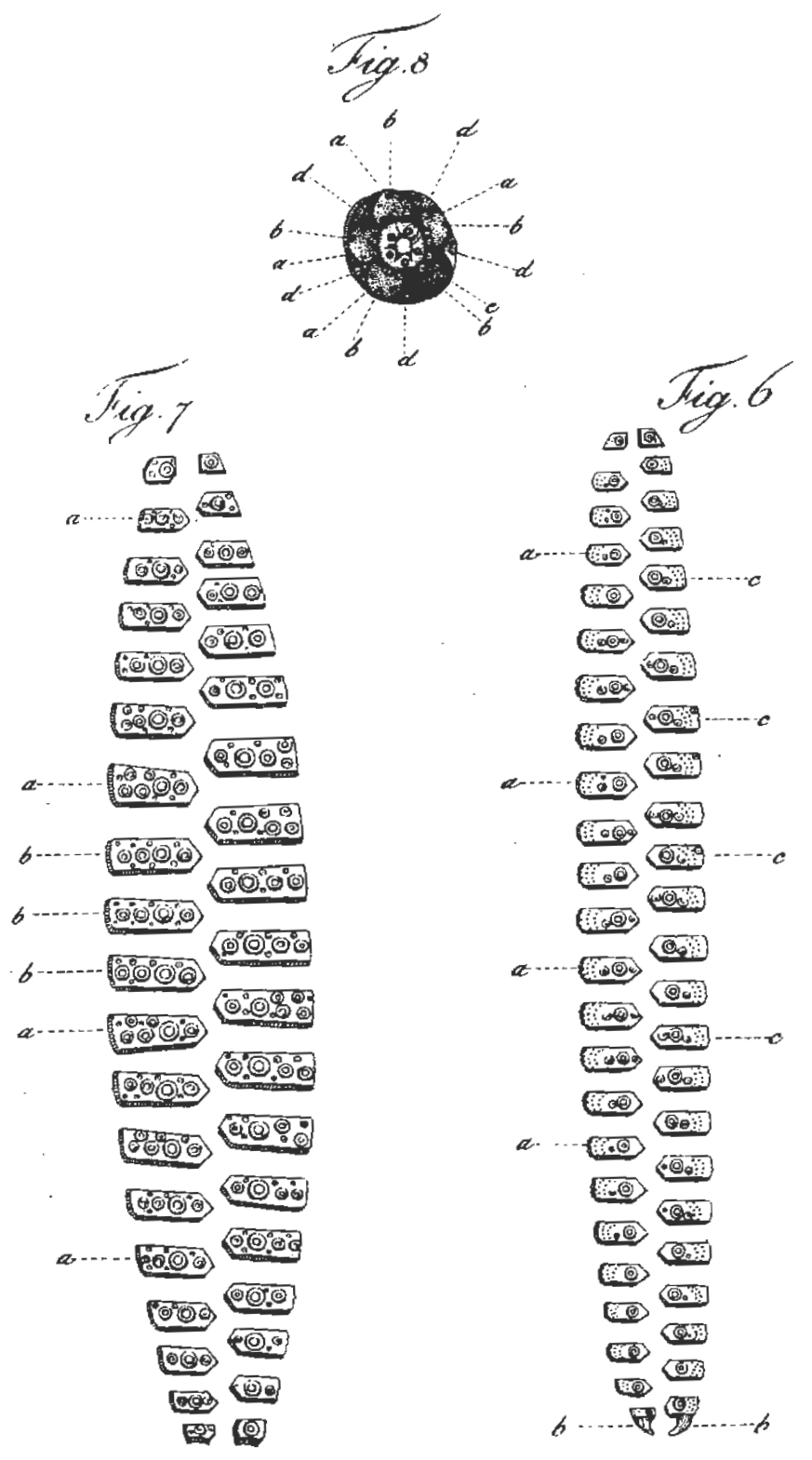

